\title{
Annotated Bibliography of Selected Themes on New Zealand Rugby Literature 1967-2003
}

\author{
by
}

\section{Rodrey Chan}

\begin{abstract}
Submitted to the School of Information Management, Victoria University of Wellington in partial fulfilment of the requirements for the degree of Master of Library and Information Studies
\end{abstract}

\section{October 2005}


VICTORIA UNIVERSITY OF WELLINGTON

Te Ware Wänanga o te Üpoko o te I ka a Mäui

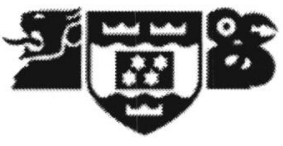

School of Information Management

Statement of Availability INFO 580 Research Project

Copies of Master of Library \& Information Studies research projects are retained in the School's research project collection, which is managed by the University Library. The author grants to the School of Information Management the right to list bibliographic details and abstracts of the projects in publicly available databases. Papers submitted in electronic form may be made available by the school on a network server. The author retains all rights to publish and/or sell the research paper by any means at any time.

The author states that the project does not violate any copyright or rights of others.

Student (Author):

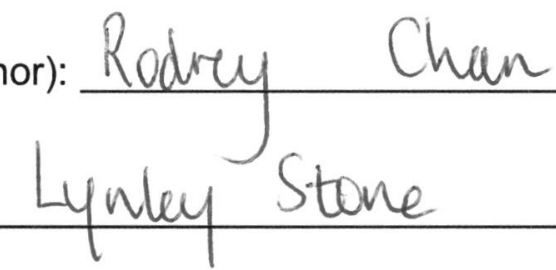

Supervisor:

Project Title:

annotated

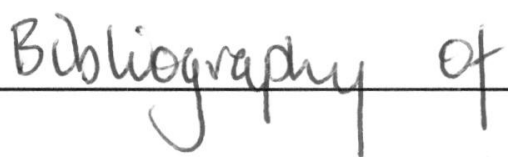

Selected Themes on New Zealand

Rugby literature 1967-2003

Year Project completed:

2005

I agree to the above conditions

Signed:

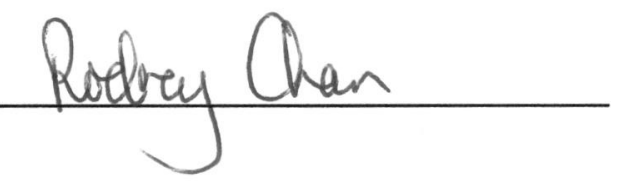

Date:

3 October 2005 


\section{Contents}

1. Introduction

2. Historical Context of Rugby in New Zealand

$2.1 \quad$ Nation building and masculinity 2

2.2 Amateurism and Professionalism 2

2.3 Violence and Discipline in rugby 5

2.4 Public's reaction to defeat 5

2.5 The movement from Conformist New Zealand to Contemporary New Zealand 5

2.6 Relationship with South Africa 5

2.7 Administration 6

2.8 Styles of Play 6

2.9 Objectives 7

2.10 Overview of key history 7

2.11 Impact of commercialization (1) International

2.12 Impact of commercialization (2) The World Cup

Timeline of important events in New Zealand
rugby history

3. Methodology 22

3.1 Research Sources 22

3.2 Evolution of New Zealand rugby literature 23

3.3 Deliminations/ Limitations 25

3.4 Arrangement 25

3.5 Need for bibliographic coverage 26

3.6 Glossary 26

4. Bibliography of Introduction and Historical Context 27

5. Bibliography 29

6. Index 165 


\section{ACKNOWLEDGEMENTS}

I would like to thank my project supervisors Kat Turner (in the initial stages), Brenda Chawner (in the middle stages) and Lynley Stone (in the latter stages) for their patience and helpful comments regarding the structure of the bibliography. I would also like to thank the New Zealand rugby community for making this sport as great as it is. 


\section{Introduction}

New Zealand has always prided itself as being the premier rugby nation. Rugby has been a major influence that has shaped the way we see ourselves. It is more than simply our national sport. Rugby has been a mirror reflecting the state of our society, our national character. Currently New Zealand rugby is experiencing a relative lean time and in any time of hardship it is common to look back and reflect on the good times while also analysing the not so good times. During the period 1998-2002 the success of the national rugby team had waned, no Bledisloe Cup which had previously been considered a given, no World Cup since 1987 and narrow last minute losses and it has been suggested by writers, supporters, talk back callers and former players that players may have attained a state of softness, greed and lack of initiative, removing them from the environment which supposedly made them strong and which they are meant to represent. The unexpected defeat by France at the semi final stage of the 1999 World Cup and the loss of sub-host status for the 2003 World Cup dealt hammer blows to its confidence in the New Zealand game and those running it. Those in charge were found guilty and vilified. In the first stage of this national enquiry the team was accused of cowardice and capitulation to the enemy. Rugby journalists and former greats described the All Blacks as spineless, clueless, leaderless, gutless, panic stricken, lacking in skills and perhaps worst of all soft up front. Embittered kiwi fans wanted a cruel and protracted revenge for what they seemed to regard as a personal betrayal. Either through gross incompetence or dereliction of duty (All Black coach) Hart had let them down (Thomas 2003, 79). These suggestions began a series of debates that continue to this day. However upon closer examination it appears that some of these concerns have been articulated before, particularly in times of disappointments and defeat. Even in times of great success there have still been voices that cry out for change or re-evaluation.

Overreaction to a rugby defeat has been a common reaction within New Zealand society as we reflect inwards and feel the need to apportion blame. The increased commercialisation that led to the success of the World Cup in 1987, the return from isolation of South Africa in 1992, the dramatic entry of professionalism in 1995 and the harsh reality of player drain are just a few issues that have enlivened or (depending on your standpoint) threatened the standing of our national sport.

Some rugby literature seeks to help illuminate and understand how rugby came to be an important nation builder with reference to Imperialism and making our way in the Commonwealth. The 1905 Originals intensified the belief of colonial physical and mental superiority. Other themes that have shaped our history have been race relations, rugby violence and its rationalization of its place in rugby, the pre-eminence of the rugby hard man and how these perceptions have changed through the era of amateurism to the age of professionalism. Many of these themes are intertwined and have influenced the style in which we have played, which in turn have influenced how we perceive ourselves through rugby, and how the rest of the world sees us through rugby. 


\section{Historical Context of Rugby in New Zealand}

The themes listed below have been chosen because of their relevance to society and society's reaction to these themes have shaped and influenced rugby in New Zealand. It is these features that have come to characterise New Zealand rugby for better or for worse since the late 1960s.

\subsection{Nation building and masculinity}

In most New Zealand schools before the second world war it was the only male winter sport available, and in many of them participation was compulsory. "Rugby was, along with drinking in public bars, one of the twin pillars of New Zealand male culture...it became a universal experience for nearly all New Zealand men" (King, 2000 387-388).

Critical analyses of New Zealand rugby have held it to embody the nation as a Pakeha masculine entity. Playing rugby is a part of a "normal" boyhood to the point where masculinity and citizenship may be suspect if a boy does not play (Park 2000, 444). The 1905 Originals intensified the belief of colonial physical and mental superiority. These analyses have focused on rugby as a site of national celebration and valorisation, the continuation of a masculine frontier ethos or the outcome of a particular pattern of colonization. Regimes of cultural power in New Zealand are fully imbricated with rugby union. Rugby is seen as significant if not instrumental, in building a nation (Maclean 2000, 257).

\subsection{Amateurism and Professionalism}

From its inception in 1892 the NZRFU (New Zealand Rugby Football Union) was obliged to observe the laws of the game and also to adhere to the game's ethic. The central tenet was amateurism which stipulated that "football should be played solely for the pleasure it afforded. Excessive striving for victory introduced an unhealthy spirit of competition, transforming a character building 'mock fight' into 'serious fighting'. Training and specialisation degraded sport to the level of work." (Vincent 1997, 92).

As early as 1907 New Zealand was seen as in serious danger by being seduced by professionalism which represented moral decay to middle class sensibilities. Professionalism was to be feared and eliminated. "Excessive competition brought unsportsmanlike, professional players into rugby, with a consequent upsurge in violence, foul play and cheating; professionals resorted to such tactics because their living depended on success at any cost" (Vincent 1998, 125). Compare this attitude towards professionalism with the accusations that are being made today now that rugby professionalism became a reality in 1995: "There is a feeling that money, the professional element of the game, had a focus and emphasis at the expense of a closer consideration of the issues and difficulties faced by the base of the game. Modern All Blacks were deemed to be professional yet pampered, athletically skilled, yet robotic, individually committed, yet passionless as a team" (Hope 2002, 235). In his editorial in the summer 2002-03 issue of New Zealand Political Review, commentator Chris Trotter laments the fact that "the professionalism of the All Blacks 
has fatally undercut the egalitarian ideals which fuelled New Zealand's abiding rugby legends. The game, once a celebration of mateship and a common national identity, has fallen victim to the same processes of commodification which have hollowed out so much of the rest of New Zealand's conceptions of itself" (Thomas 2003, 12).

\subsection{Violence and Discipline in rugby}

A retired player claimed in 1908 'the game is rougher here than in Australia, and certainly infinitely rougher than in any part of the British Isles where Rugby is played'. (Vincent 1997, 104).

The roughness of rugby may have made it more appealing to groups among whom traditional concepts of masculinity continued to prevail. Were this so, it would explain why rugby became firmly rooted in New Zealand where the occupational base encouraged the retention of standards of masculinity in which physical toughness, strength and courage were emphasised.

The most notable episodes of rugby violence have been the sending off from the field of play of Cyril Brownlie (1924 v England) and Colin Meads (1967 v Scotland). On both occasions the players were treated sympathetically by the New Zealand public, incensed that their heroes had been singled out. They were viewed as victims rather than perpetrators. In his 1967 tour account All Black Magic prominent rugby writer TP McLean's view of the dismissal of Meads from Murrayfield was a clash of rugby philosophies which had caused and would continue to cause much tension between New Zealand and the Home Unions. Meads was a product of the New Zealand school of rucking which maintains that if a man is lying on the ground, illegally obstructing the opposition from gaining the ball, it is then legitimate to use the feet to heel it back. In contrast, the British philosophy holds that it is unavoidable that players will be trapped on the ground, thus impeding the free passage of the ball, therefore any attempt to ruck is seen at best overvigorous play and at worse foul or violent play. From a New Zealand perspective, the implication of such a lenient interpretation of the rules will inevitably be abused by teams to 'kill' or stop the opposition from gaining possession. In Britain the New Zealand philosophy towards this kind of play is interpreted as unfair and cruel. Two such distinct philosophies suggest there is no generally accepted way of playing nor any widely agreed interpretation of the rules. This is in turn indicates that sport does not work in isolation from day to day activities, but is reflective of the attitudes of the society in which it operates. In short the New Zealand approach to rucking reflected a pragmatic and harsh attitude. This was reinforced later when a strong Irish and British Isles team toured New Zealand in 1971. Frustrated by the success of the 1971 Lions tactic of lying on the ball hence preventing quick ball for the All Blacks to create irresistible momentum the New Zealand coach Ivan Vodanovich warned that "Carisbrook could become another Passchendaele" (McLean 1971,101).

Richard Kay expounds that McLean regarded the 1960s and early 1970s as the age of violence and McLean was frustrated that the concept of rugby fostering manly qualities has been taken to ridiculous lengths. 
Violent play has been associated with "manliness" and controlled aggression, and sometimes, uncontrolled play such as punching in response to provocation. On the other hand foul play has been associated with cowardly, underhand, unsporting play such as kicking a man on the ground. But the New Zealand public still has a soft spot for the hard man in the team if talkback radio is anything to go by. "They rarely ask about the clean-cut hero, or the sports event that ended fair and square and without incident. No, they want to know about the sportsman who did not do the right thing, the winner who should have lost, or the loser who should have won. They are fascinated by the villain of the piece" (Bickerstaff 1998, 6 ).

The way New Zealand plays its rugby and conducts its affairs has often attracted antagonism from the British Press. Though Britain is soccer-sated, the coverage of rugby has increased since the early 1970s. With that increase has come a greater willingness to go beyond mere reportage to strident calls for action on this or that front or condemnation of this or that action. All Blacks first noticed the change in 1972 when Ian Kirkpatrick's All Blacks were painted as unsmiling giants and when Keith Murdoch gave the papers a ready-made villain from his escapades in South Africa 1970. It has continued on subsequent tours, incidents signposting the years: the Andy Haden's lineout dive and the battle of Bridgend and John Ashworth's sprigging of J.P.R. Williams face in 1978; the 'sending off' of Graeme Higginson against Llanelli in 1980; Wayne Shelford and the All Blacks generally supposedly flouting amateur regulations in $1989 \ldots$ the list goes on.

Wise All Blacks don't read newspapers. But the public do and if the English public is told day after day that the All Blacks are dirty cheats who will stop at nothing to win at matches, that in the end that is what the public will believe.

This was the climate in which the All Blacks played England in 1993. Even the England captain, Will Carling, wrote a column at the end of that tour saying that the All Blacks will be remembered as a dirty side.

Colin Welland, a playwright with a fondness for league, wrote a damning piece about New Zealand rugby generally. After the All Blacks had been beaten by England, he wrote: “"The beating of a bully is always great theatre and the bashing of the All Black brutes was in the Palladium class. It was a wonderful occasion, alongside Great Britain's rugby league win in Melbourne last year (1992) in my tales of the unexpected. That was sweet, but Twickenham, with the element of good versus evil, shades it by a whisker'. Welland clearly thought New Zealand put too much emphasis on rugby. 'New Zealand, you must reweigh your values' he said. 'A national disaster', (Ian) Kirkpatrick, called your defeat. Codswallop! If that's what you think, what your country thinks, its time you both grew up. What we all cheered at Twickers was not just the winning of the test but the defeat of an attitude... an archaic, unsavoury attitude which somehow has survived and festered in the dark bottom right-hand corner of the globe. The world is 
maturing around you. Get with it, mend your ways, take another look at yourselves... or you wont be invited again."' (Palenski, 2003, 34,36).

\subsection{Public's reaction to defeat}

"If the public is benignly tolerant when the All Blacks are winning, it is unforgiving when they lose. And lose they did in 1998 - five games on the trot. The public still has not recovered its sense of well being- and here or its sense of humour" (Thomas 2003,13). Defeat at the hands of France in the 1999 World Cup semifinal was simply unpalatable. Having beaten the French earlier in the year by 50 points the All Blacks were hot favourites to win through to the final. Defeat was a shock to the New Zealand public and the pain of this early exit focused the fans anger onto coach John Hart. He was vilified on talkback radio. He received hate mail, including death threats. At Addington Raceway people threw things at his horse (Thomas 2003, 80). If All Black performances were a measure of national accomplishment then All Black deficiencies were also national deficiencies. After that semi final debacle one sports editor felt compelled to ask 'are we becoming a nation of chokers' (Hope 2002, 250).

\subsection{The movement from Conformist New Zealand to Contemporary New Zealand}

Chris Laidlaw, rugby legend and Rhodes scholar produced a book Mud In Your Eye: A worms eye view of the changing world of rugby (1973) which proved a major rugby event in itself when he brought an antagonistic insight on the national game. Among the aspects he found fault with were the widespread compulsion to play rugby and the cult of conformity within the game, which had become a liability in an era of rebellion and social upheaval. Today New Zealand rugby is no longer essentially the preserve of white adult males, some of whom, particularly those who can remember when that was the case feel 'disenfranchised'. Rugby in New Zealand has undergone rapid, startling change, much of it reflecting the seismic social and economic changes that have shaken up the nation in the last two decades. 'In 1960 the claim that New Zealand was "98.5 per cent British" could still be heard. Today there is considerable ethnic diversity, especially in Auckland where almost 10 per cent of the population is Asian, 13 percent Pacific Island and 12 per cent Maori. New Zealand will never go back to being a homogenised society and the All Blacks culture must adapt to survive accordingly' (Thomas 2003, 115).

\subsection{Relationship with South Africa}

Throughout the saga of New Zealand-South Africa rugby, there has always been 'if only's' and 'could have's'. If the 1928 series had been won by the All Blacks, as perhaps it may have been if off-field politics hadn't determined selections; if the wise counsel of Danie Craven and Philip Nel hadn't prevailed when the Springboks were in New Zealand in 1937, the All Blacks surely would have won that series as well. And if those two series had been won, would New Zealand have remained as obsessed with beating South Africa as it did? Would the national crusade have had the same intensity? Would New Zealand rugby, so at odds 
with the rest of the country, have been so hellbent on bringing the Springboks to New Zealand in 1981 when the whole world knew such a tour was dangerous folly.

The intense focus on issues of race and racism and the passions these generated through involvement with rugby union created an environment conducive to a more comprehensive assessment of New Zealand's colonial experience and the position of Maori in contemporary society. On the other side of the coin rugby's significant role in New Zealand's received hegemonic national identity and the traditional importance placed on competition with South Africa combined to make attendance at All Black Springbok matches akin to visiting the temple. This secular sacredness meant that these contests needed to be isolated from the profane world of politics and the sacrilege of those who would challenge those identities (Maclean 2000, 269). Up until 1960 the morals of playing a racially selected Springbok team were rarely discussed. In the wake of African nationalism and a growing awareness of the vulgar principles behind apartheid the voice of protest began to increase markedly in volume. Vocalised by protest groups such as HART and CARE growing unrest climaxed with the violent civil disruptions that erupted during the 1981 Springbok tour of New Zealand. 'Up until 1981 rugby had been a comfort blanket for the countrynow it was a hair shirt. Where once it had brought people together, it had now become an agent of social destruction.' (Smith 1999, 163).

\subsection{Administration}

Strong criticisms of the sports administrators in this country has not been a recent phenomenon. Small comfort to those who have been vilified while trying to run the game here is that T.P. McLean throughout his works in the 1960s and 1970s had been a staunch critic of the New Zealand Rugby Union Councillors whom he believed were holding the game back through their entrenched attitudes and methods, hostile to change within the game and New Zealand society. He believed that the NZRFU had failed New Zealand with not acting on issues such as violence of the game, the style of game, the policy regarding South Africa and providing live television coverage of test matches. Put simply the Council had become 'too powerful for its own good'. (McLean 1972, 64).

\subsection{Styles of play}

Some traditionalists are unimpressed by the extravagant movement and points scoring in many matches nowadays. The game, they complain, has become 'airy-fairy'. Their game was being robbed of the very quality which has for a hundred years fired New Zealanders' passion for the game - the physical struggle of good old-fashioned forward play. Therefore it could be argued that the fans that packed the grounds back in the 1950s and 1960s - no live television - had quite different expectations from today's spectators. Yet T.P. McLean's Kings of Rugby shows the New Zealand rugby public of 1959 hungered for a more vibrant and attacking style of play from the men in black. When they got more of the same-space suffocating forward 
play and the siege gun goal kicking of Don "The Boot" Clarke - they switched their support to the visitors who sought to win the by using their backs to score tries. "The unpleasant, unpalatable and unavoidable fact was that the world champion nation was neither playing a game suitable to its station nor looked capable of playing such a game" (McLean 1959, 59). Now the wheel has turned. Former Welsh fly half Jonathan Davies regarded the back play of the 2002 All Blacks who toured Europe as the most exciting and innovative he had seen since 1995, when New Zealand electrified a watching world and in the process persuaded Rupert Murdoch to underwrite the professionalisation of Southern Hemisphere rugby (Thomas 2003, 54).

\subsection{Objectives}

The objectives of this bibliography are as follows (all refer to the period 1967-2003)

- Evaluate rugby union literature concerning nation building and masculinity

- Contrast literature on New Zealand rugby violence and discipline by highlighting the progressive debates that emerged during 1967-2003

- Contrast literature concerning the development and evolution of commercialism / professionalism of New Zealand rugby union with the arguments for maintaining strict amateurism.

- Evaluate and contrast the literature focusing on New Zealand's rugby relationship with apartheid South Africa

- Evaluate and contrast the literature concerning the evolution of New Zealand style and the factors that have influenced this.

- Evaluate and contrast the literature that criticizes the administration of the New Zealand game

- Contrast the literature that illustrates the changing demographics of rugby union in New Zealand.

- Evaluate the literature that covers the public reaction to defeat of the All Blacks.

This scenario thus presents an opportunity to compile a retrospective review of literature on New Zealand Rugby Union, firstly in order to analyse themes raised by authors from the 1960 s to early 2000 s and secondly to identify instances where authors have a contrasting view.

\subsection{Overview of key history}

Rugby in New Zealand was introduced by Charles Munroe, with the first official game being played in 1870. It very quickly spread to every corner of this country with the New Zealand Rugby Union being formed in 1892. The first official test was in 1903, in Sydney. The highlight of New Zealand's first decade 
of test play was undoubtedly the epic and outstandingly successful 35 match tour of the British Isles, France and America during which the name 'All Blacks' was coined. The success of this team was attributed to the healthy lifestyle of the pioneer colony.

In 1908 the New Zealand and New South Wales unions were concerned about the beginnings of rugby league as a competing sport and a professional one at that and the English union, which then ruled the administrative roost, was alarmed by what it feared was a dilution of amateurism as the two far-off colonies grappled with keeping players from their rival off-shoot. The 1908 Anglo-Welsh tour of New Zealand was marred by British accusations of over-vigorous play from the New Zealanders. The Anglo-Welsh team manager George Harnett then didn't endear himself to New Zealanders when he criticized the play of the wing forward as 'nothing but an obstructionist and always offside'. His successor James Baxter, manager of the 1930 Great Britain team that toured New Zealand continued on this theme saying 'It is contrary to the spirit of rugby football' (Palenski 2003, 115). The tone of the message was clear: The New Zealanders may be successful on the field of play but were lacking in amateur and gentlemanly etiquette.

The second decade of All Black rugby was severely interrupted by World War 1 but was characterized by the first test series between South Africa and New Zealand in 1921when the Springboks first visited the Shaky Isles. The tour was slighted by South African reports that were scathing of the home crowd who openly cheered the Maori team against the Springboks. The two leading rugby nations drew the series between themselves.

The second All Blacks team who traveled to the United Kingdom and France in 1924 became known as the "Invincibles" winning all their matches, a feat that has never been replicated on a major tour by any country. While there was controversy with All Black forward Cyril Brownlie becoming the first player to be sent off for supposed foul play against England it only added to the legend of the team when the All Blacks overcame this obstacle and remained victorious. Throughout the tour the kiwi forwards were matched and sometimes bettered by their hosts but the superior back play that had characterized previous New Zealand teams allowed the All Blacks to maintain dominance over their opponents.

The first All Black tour to South Africa in 1928 was another close affair with the two giants of the sport again level after a series of 4 test matches. The following year New Zealand would lose a series to Australia for the first time.

The Great Britain team, precursor to the Lions made their first tour of New Zealand in 1930. While the All Blacks proved victorious, further complaints were raised about the roughness and intensity of the New Zealand game. Accusations of cheating were also raised by the Great Britain team manager James Baxter with New Zealand's continued use of the wing forward. 
At this juncture New Zealand was in the midst of suffering the Great Depression and this forced many rugby players to change codes, and play rugby league professionally. This included legends such as George Nepia and Bert Cooke.

The next major tour was the 1935-36 All Black tour to Ireland and the United Kingdom. In another long tour the All Blacks lost only one game until the final week where they lost to England for the first time and Wales for just the second. British rugby had made tremendous strides to now seriously challenge New Zealand's place as a dominant power in the game. The Springboks would inflict further misery on New Zealand with their 2-1 series win in New Zealand thus becoming the undisputed albeit unofficial world champions of rugby. This would drive New Zealanders almost crazy with their desire and obsession to beat their great rivals. Their big chance for revenge in 1940 would be dashed with the outbreak of World War 2 .

With the end of the Second World War the rugby team of the $2^{\text {nd }}$ New Zealand Expeditionary Force, known as the "Kiwis", undertook an arduous tour of England, Scotland and Wales, then on to France and Germany before returning home to another five games against New Zealand provincial sides before they were finally reunited with their families. In total they won 32 of the 38 games they played. The style of rugby was fast, open and highly entertaining and, in the immediate post-war era when people were starved of entertainment of any kind, was received with enthusiasm and accolades wherever they played. Once back in New Zealand, many of the team went on to become All Blacks, coaches and selectors, including great names such as Bob Scott, Fred Allen and Charlie Saxton.

New Zealand resumed their rivalry with South Africa in 1949 with the All Blacks touring the Republic. However despite scoring more tries than the hosts the All Blacks were beaten in every test. The main reason was the superior scrum techniques of the South Africans and their effective power play, with the absence of back play. This result would greatly influence the style that New Zealand would undertake for the best part of the next 20 years.

The 1950s and 1960s was a very successful period for New Zealand but this success was blighted by a perception that while New Zealand played winning rugby it was not attractive rugby, dominated by the adopted power game borrowed from the Springboks a reluctance to use their backs, relying on a magnificent forward pack that would bludgeon the opposition into submission. It was a style that at times would attract violence, and although successful the New Zealand public would at times clamor for a more exciting attacking style. The confrontational abrasive philosophy that now dominated New Zealand's rugby landscape certainly brought rewards: victory over a popular Lions team in 1950, continued domination in the Bledisloe Cup which represented trans-tasman competition with neighbours Australia, victory over the Springboks for the first time in a series in the 1956 campaign - which confirmed the success of the power 
game, and victory over a powerful Lions team in 1959. It was this tour however that the New Zealand public gave voice to their growing disquiet of the power game that had reduced attacking back play to chasing kicks. Dunedin, scene of the first test where the Lions dazzled with their brilliant backs, scoring 4 tries yet would lose to the All Black's 6 penalties kicked by Don Clarke. The crowd, far from being pleased with a win cheered the Lions, chanted "Red, Red, Red!" and generally berated the All Black performance. But while the style brought success it would suffice for the present.

The decade of the 1960s continued in the same vein. Despite losing a close series in South Africa in 1960 the conservative tactics remained as did victory against the French in 1961, England in 1962 and a successful tour to the Northern Hemisphere led by captain Wilson Whineray in 1963-64. The 1965 Springboks touring New Zealand were beaten most convincingly. But still there was an undercurrent of feeling that New Zealand was not playing as the premier rugby nation should. Before 1950 New Zealand had mesmerized their opponents with attacking back play. There was a strong desire by many quarters to redress the balance.

With the appointment of Fred Allen as All Black coach in 1966 there was a concerted effort to reclaim the running game that characterized New Zealand rugby until 1950. The 1966 Lions were battered into submission losing all 4 tests. The 1967 tour to the British Isles and France, a replacement for the cancelled tour to South Africa was a return to adventurous rugby. This success was maintained until the 1970 tour to South Africa where ironically the team overplayed the adventurous rugby and paid the price for not applying a more measured and conservative approach in the test matches which they lost 1-3. This ended a most successful period for New Zealand and they entered a period of rebuilding which coincided in the visit of a powerful Lions team coached by Carywn James and containing some of the best players ever to come out of the British Isles and Ireland. In a close series the Lions prevailed 2-1 with the last test drawn. The Canterbury game became notorious for its violence and ending the tour through violence inspired injury for two of the Lions. New Zealand rugby undertook criticism that it had not evolved and was still stuck in the 1960s. With forward play seen to be stalling the next tour to the Northern Hemisphere in $1972-$ 73 which happened to be the last great tour with respect to the number of matches was seen as a launching pad for a new dynasty of kiwi dominance. With British rugby enjoying halcyon days it was expected to be a great challenge. What was not expected was the vitriolic bitterness on and off the field which climaxed with the sending home of hard man Keith Murdoch after the Welsh test for punching a security guard in the Angel Hotel.

1973 was a relatively quiet year for New Zealand. The proposed Springbok tour to New Zealand was cancelled due to the Kirk Labour government refusal to issue visas to the South Africans. The sole test was a disappointing loss at home to England. 1974 saw an improvement in fortune with undefeated tours of Australia and to the Northern Hemisphere to participate in Irelands' centenary where they also played 
Wales in an unofficial test and the Barbarians who were the 1974 Lions in disguise. This All Black team won praise for again trying to play adventurous attacking rugby and compared well to the dour tactics of the $1972-73$ team.

The next big tour was a return to South Africa in 1976, led by Andy Leslie and coached by JJ Stewart. The team came unstuck through a combination of poor selection, poor goal kicking, violence and accusations of biased hometown refereeing. These test matches were broadcast live to New Zealand viewers who could see the controversy with their own eyes.

The Lions returned to New Zealand in 1977 expecting to do well. Despite dominating the All Blacks in the tight play, the back play from the visitors proved inferior to the New Zealanders which enabled the hosts to win the series 3-1. The tour was blighted by accusations from the Lions that the crowd animosity towards the visitors overstepped boundaries of decency. Later that year New Zealand undertook a tour to France where the series was drawn one test apiece, again on-field violence including eye gouging from the French being a major characteristic.

The much improved Australian Wallabies were the tourists in 1978 and despite losing the series handed New Zealand a record defeat in the third and last test. A tour to Ireland and the British Isles and the opportunity to claim that elusive Grand Slam awaited the team at the end of the year. Praised for their leadership, management and never-say die attitude the All Blacks succeeded in defeating Ireland, Wales, England and Scotland.

However ill feeling and controversy on the tour still dogged the team highlighted by Andy Haden's dive from the lineout in the dying seconds of the Welsh test in an attempt to trick the referee into awarding a penalty to New Zealand. Although the referee awarded the All Blacks a penalty for a different offence, Haden's intent was deemed cheating. Wales, having lost a closely fought test at the death, seethed. In the last club game in Wales against Bridgend John Ashworth raked his sprigs down the cheek of Welsh hero JPR Williams causing a severe gash. By this time the Welsh crowd were apocalyptic. Williams father voiced his disgust at the official match dinner, which caused some members of both teams to walk out in protest. This bitterness would not be resolved until the Welsh centenary celebrations in 1980.

In 1979 the French dazzled the New Zealand public with a brilliant display in the second test played on Bastille Day to level the series and the Bledisloe Cup would be lost to Australia for the first time since 1949. Australia confirmed their growing reputation as a worthy adversary by successfully holding the Bledisloe Cup with a 2-1 series victory over the All Blacks in Australia the following year. It was in the third test where the All Blacks were badly affected by food poisoning with accusations of conspiracy leveled towards the Australians. Similar allegations would resurface 15 years later during the World Cup 
finals. These disappointments would be forgotten with the champagne rugby played by the All Blacks as they swept through Wales undefeated. Much goodwill was restored between the two rugby tribes after almost a decade of unhealthy antagonism and bitterness.

The growing divide over Rugby's continued relationship with apartheid South Africa came to a head in 1981 with the Springboks touring New Zealand. Protests against the tour became a regular feature in a winter that would split communities and families and almost reduced New Zealand to a state of civil war. Two of the tour matches were cancelled and other matches on the tour became a flashpoint of violence between Police and protestors. Coinciding with an alarming incidence of spinal injuries on the field and an upsurge in the popularity of soccer, the Springbok tour was almost the last straw for New Zealand rugby.

1982 saw the emphasis return to the field where a young Wallaby team captained by Mark Ella and coached by Bob Dywer played entertaining adventurous rugby that enthralled the crowds. Unfortunately this rich attacking vein was not maintained by a poor Lions team in 1983, which was beaten in every test by a superior All Black team. The end of year tour to England and Scotland became notable for the fact that many of the incumbent All Blacks made themselves unavailable. Since 1977 the All Blacks had made 6 end-of-year tours in 7 years. For the amateur player this was becoming too much of a demand of their time. With young families to look after and their jobs put on hold the lack of remuneration was beginning to bite deep.

The impact of the 1981 Springbok tour had not lost its resonance when the proposed All Black tour to South Africa in 1985 approached. The team was prevented from going by a high court injunction initiated by two rugby supporting lawyers who argued that the tour to the republic was not in the best interests of New Zealand rugby. This gave birth to the rebel 'Cavaliers' who traveled for an illegal and unofficial tour of South Africa. This lead to the players having a two-match ban imposed on them by the NZRFU when they returned home. Allegations that they had received payment for playing were never proven. This ban would prove both bitter and sweet for the All Blacks. Bitter because it caused friction and tension within the All Black camp and the ban helped the Wallabies win the Bledisloe Cup later that year, sweet because it enabled New Zealand to blood new players who would create their own legend by defeating the more experienced French as the "Baby Blacks" and provide the core of players who would win New Zealand the inaugural World Cup the following year. The end of year tour to France handed the All Blacks a notorious defeat in the second test in Nantes, humbled by Gallic passion and brutality.

The World Cup of 1987 brought a new dimension to international competition. A singular tournament to allow the victor to be proclaimed as "Champion of the World" also offered the commercial opportunities that would usher in the approaching professional era. New Zealand and Australia had worked hard together to convince their skeptical IRB brothers-in-arms that a World Cup was indeed feasible. There had been much consultation about when a World Cup would be held; the where was easier- the impetus had come 
from New Zealand and Australia and that was where it would be. A superbly prepared All Black side, playing an innovative style of rugby, was easily the best team on display at the first World Cup, comfortably beating France $29-9$ in the final at Eden Park.

New Zealand's absolute dominance continued for the next 3 years, crushing all those who stood in their way. A world record stretch of 50 matches without defeat underlined the edge the All Blacks had over their opponents where victory often became a rout. Australia, France, Wales, Ireland, Argentina and Scotland all fell by the wayside. Finally in 1990 with the Bledisloe Cup safe after winning the first 2 tests, New Zealand succumbed to a fired up Wallaby team in Wellington. This underlined the end of absolute dominance enjoyed by the All Blacks and was further emphasized by the shock defeat at the hands of Australia in the World Cup semi-final in Dublin. Australia confirmed themselves as genuine contenders for the world rugby crown, something that would greatly irritate New Zealanders.

The challenge now was to return New Zealand to the undisputed top of the rugby tree. Celebrating the centenary of the NZRFU the All Blacks under coach Laurie Mains defeated a World XV, Ireland then lost the Bledisloe Cup to the World Champion Wallabies in a close series. The highlight of the year was the first victory at Ellis Park for 65 years when New Zealand-South Africa contests resumed after the return of the Springboks from isolation. 1993 and 1994 saw mixed All Black fortunes. The highs were the defeat of the Lions and Springboks at home and the return of the Bledisloe Cup. The lows were the losses to England at Twickenham and to France at home.

In the last significant amateur rugby event the third World Cup in South Africa 1995 had the All Blacks playing brilliant rugby before yielding to South Africa in the final, their effectiveness diminished by food poisoning. After the World Cup New Zealand continued their impressive form to defeat Australia convincingly home and away.

Under John Hart's initial guidance as coach, the All Blacks dominated: they won the Tri-Nations in 1996 and a landmark series victory on South African soil. The All Blacks won the Tri-Nations again in 1997 before coming unstuck in 1998 with 5 consecutive losses to Australia and South Africa. Further disappointment followed in 1999 when New Zealand fell to France in the fourth World Cup for the second time in the 1990s.

New Zealand turned their hopes to new coaches Wayne Smith and Tony Gilbert in 2000. After promising starts in the Tri-Nations the All Blacks lost in the dying seconds against Australia and South Africa, in doing so handing the Bledisloe Cup and the Tri-Nations to the Wallabies. An end of year tour to France saw a decisive defeat at the hands of the Tri-colors which further exposed weaknesses in the forward pack. 2001 did not see an end to the last second defeat frustration. Despite beating the Springboks, the All Blacks 
continued to struggle against Australia losing twice and the Sydney defeat again in the last seconds. For two seasons now the All Blacks had been denied trophy success. Smith and Gilbert were then replaced by John Mitchell and Robbie Deans who began to replace some of the experienced stars with new blood. TriNations success in 2002 was offset with yet another last minute loss to Australia for the Bledisloe Cup. Australia had now held the symbol of trans-Tasman supremacy for 5 years. To New Zealand rugby fans this was an eternity. The World Cup year of 2003 offered plenty of promise and despite a narrow loss to England, the All Blacks suddenly hit form and handed out record thrashings to their Tri-Nations partners and the long awaited return of the Bledisloe Cup. Hopes were high that the World Cup would come home and New Zealand entered their semi-final against the Wallabies as hot favourites. Alas, the World Cup curse continued with the Australians belying their previous ordinary form to play like men possessed, strangling New Zealand out of the Cup. The biggest prize of all would keep New Zealand waiting in the taunting words of Australian skipper George Gregan for at least "Four more years!"

\subsection{Impact of the commercialization of rugby (1):}

\section{International Provincial Championships}

Various early-season competitions were played from the mid-1980s, usually involving the bigger first division unions, but it was only in the year of rugby's tumultuous change, 1995 that a nationwide competition was agreed. The greatest single event in the evolution of the game generally, occurred when the International Rugby Board (IRB) spell out announced that rugby would become professional. Until that epic decision, rugby was amateur and if you wanted to play for money you switched to league. Faced with this escalating threat from rugby league, the national rugby unions of New Zealand, Australia and South Africa jointly approached the multinational news media company, News Corporation, with a commercial proposition. The three unions formed themselves into SANZAR together sold the rights for all their domestic and test rugby for 10 years for \$US550 million. The sale was made up of three elements - an early season competition called the International Provincial Championship (IPC) later renamed the Super 12, a tri-nations test series, and their main domestic competitions which, in New Zealand's case, the national provincial championship.

The agreement was announced in Johannesburg on the eve of the 1995 World Cup final but, unknown to the administrators, the players had ideas of their own. Most had indicated a willingness to join the Australian-based World Rugby Corporation, which had rugby "globalization" plans of its own, plans which precluded the involvement of the game's governing bodies. Without the players, the News Corp deal would have faltered if not folded, but by the end of the 1995 season the national unions had reached agreement with most players and it was the WRC that foundered.

The IPC, in a New Zealand context, called for the top 165 players in new Zealand to be distributed equally among five teams formed solely for playing the Super 12, and former All Black selector, Peter Thorburn, 
was made IPC commissioner for the first year to ensure this would happen. The teams, which modern rugby administration calls franchises, were the Auckland Blues (Auckland and Counties-Manukau), the Waikato Chiefs (Waikato, North Harbour, Northland, Thames Valley, Bay of Plenty, King Country), the Wellington Hurricanes (Wellington, Manawatu, Hawkes Bay, Wairarapa-Bush, Horowhenua, Wanganui, Taranaki, Poverty Bay, East Coast), the Canterbury Crusaders (Canterbury, Mid and South Canterbury, Marlborough, Nelson Bays, Buller, West Coast) and the Otago Highlanders (Otago, North Otago,

Southland). The guiding principle, which reality did not always mirror, was that teams would be evenly matched and that leading players in lesser provinces would not be penalized. A draft system was introduced to oversee the ideal of an even player spread.

\subsection{Impact of the commercialization of rugby (2):}

\section{The World Cup Sub-hosting debacle and the Eichelbaum Report}

Australia and New Zealand were to host the 2003 World Cup however breakdown in the finer details of negotiating saw New Zealand dumped as sub-host and Australia became sole host. New Zealand's failure to retain the sub-hosting rights to the 2003 World Cup saw the New Zealand union painted as uncommitted to the cup and incompetent; the Australians were painted as greedy and duplicitous and the International Rugby Board was painted as leaderless, confused and indecisive. The investigation and report by the retired Chief Justice, Sir Thomas Eichelbaum, couldn't tell the whole story because he could only report and comment on what he was told or what he knew: like a good judge, he could only go on the evidence before him. But even if incomplete, it was damning.

No less damning was the reaction from the IRB, itself far from blameless in the sorry affair. When New Zealand's last-ditch appeal to the IRB's decision-making council failed in April 2002, the IRB had this to say: 'Generous accommodations made by RWCL (Rugby World Cup Ltd) to meet the needs and problems of the NZRFU were repaid with consistent failures and wholly inappropriate behaviour...'

Not even when South Africa was being vilified by the rest of the world did the IRB utter such a strong condemnation of one of its members.

There was clearly fault in all three key sides: the IRB's (the cup company) for not being specific enough about what it meant by clean grounds, a phrase that had been used as early as the first World Cup but which then did not include corporate boxes or precincts outside stadiums; Australia's for an apparent unwillingness to negotiate with New Zealand in the latter stages when it became obvious negotiation and goodwill was sorely needed; New Zealand's for a lack of commitment to the cup, for creating the impression that the NPC was more important than the cup, and for failing to acknowledge until it was too late precisely what was meant by clean grounds. Jointly the IRB and the NZRFU were at fault for relying on 'an understanding' that 100 per cent clean grounds didn't have to necessarily mean what it said. These and the ever-present money, were the central issues and when they became mixed with personality 
differences, dislikes and mistrust, it all became too much. New Zealand's underlying argument throughout the saga was the need for a 'rugby solution' rather than one based entirely on contracts and who got what amounts of money. New Zealand's long and honourable role in world rugby was used in emotional but unrequited pleas for understanding. The reaction by the public, including the provincial unions, to the whole debacle was overwhelmingly damning. It was New Zealand rugby administration's darkest period.

(Palenski, 2003, 234).

\subsection{Timeline of important events in New Zealand Rugby history}

1870

1875

1879

1882

1884

1888

1892

1893

1894

1896

1897

1902

1903

1904

1905

1905-06

1907

First rugby match in New Zealand at Nelson

First tour of New Zealand by a provincial team (Auckland) and the first inter-provincial match (Auckland clubs v Dunedin clubs at Dunedin, 22 September)

First unions (Canterbury and Wellington founded)

First visit to New Zealand by an overseas team (New South Wales)

Points system of scoring adopted: try 1 point, conversion 2 , other goals 3

First visit to New Zealand by a British team.

New Zealand "Natives" tour of New Zealand, Australia and United Kingdom

Formation of the New Zealand Rugby Union

Scoring values revised: try 2 points, conversion 3, penalty goal 3, dropped goal 4

First New Zealand team selected under the auspices of the NZRFU (Australia)

Further revision of points system: try 3 points, conversion 2, penalty goal 3 , dropped goal and goal from mark 4

First visit to New Zealand by Queensland

First inter-island game (at Wellington, 26 June)

Ranfurly Shield presented to the NZRFU by the Governor of New Zealand, Earl of Ranfurly (Auckland was the first holder)

First full-scale international played by New Zealand (v Australia at Sydney)

First full-scale international match played by New Zealand at home (v Great Britain at Wellington)

First visit to New Zealand by a fully representative Australian team

"Originals" tour to the United Kingdom, Ireland and France

First encounter in New Zealand with professionalism when a national team, to be dubbed the "All Golds" left for matches in Australia and England 

Christchurch when he gave a commentary on the Christchurch v High School Old Boys game, 29 May

Great Britain tour of New Zealand. New Zealand wore white jerseys to avoid clashing with the dark jerseys of the visitors

Bledisloe Cup presented by Lord Bledisloe, Governor-General of New Zealand, for competition between and Australia and New Zealand.

The last season for New Zealand's traditional 2-3-2 scrum and the wing forward when the two-fronted scrum was outlawed by the International Board 
New Zealand admitted to International Rugby Board

1949

1950

1953-54

1956

1959

1960

1961

1963

1963-64

1965

1966

1967

1968

1969

1970

1971

1972

1972-73

1973
New Zealand played six tests and lost them all-four against South Africa and two against Australia

Lions tour of New Zealand. All Blacks win series 3-0 and a draw

All Blacks tour of United Kingdom, Ireland and France.

All Blacks defeat South Africa in series for first time during tour of New Zealand

Lions tour of New Zealand

All Blacks tour South Africa. All Blacks lose series 1-2

$1^{\text {st }}$ French tour of New Zealand

$1^{\text {st }}$ English tour of New Zealand

Wilson Whineray's All Blacks tour United Kingdom, Ireland and France

South Africa tour of New Zealand. All Blacks win series 3-1

Lions tour of New Zealand. All Blacks win series 4-0

Proposed All Black tour of South Africa cancelled due to refusal of South African authorities to allow non-whites in NZ team

New Zealand tour United Kingdom and France instead.

France tour New Zealand

First Welsh tour to New Zealand

New Zealand tour South Africa. All Blacks officially include non-whites for the first time in South Africa. All Blacks lose series 1-3

Lions tour New Zealand and win series for first time 2-1

"Woeful" Wallabies tour New Zealand. Live telecast of test match in New Zealand for the first time.

Value of a try increased from 3 to 4 points

New Zealand tour United Kingdom, Ireland and France.

First direct telecast by satellite of a test match (New Zealand v Wales at Cardiff)

Keith Murdoch sent home for "bad behaviour"

Scheduled South African tour of New Zealand cancelled after the Labour Government intervention

England tour New Zealand and beat All Blacks in sole test 
New Zealand tour Australia. All Blacks win series 2-0

New Zealand tour Ireland to celebrate Irish centenary

First visit to New Zealand by Scotland

First visit to New Zealand by Ireland

New Zealand tour South Africa. All Blacks lose series 1-3

African nations boycott Montreal Olympics

The National Provincial Championship established

Lions tour New Zealand. All Blacks win series 3-1

New Zealand tours France. All Blacks level series 1-1

Australia tours New Zealand. All Blacks win series 2-1

New Zealand tour United Kingdom and Ireland. All Blacks win coveted Grand Slam for the first time.

France tours New Zealand. Series drawn 1-1.

Australia wins Bledisloe Cup for the first time since 1949

New Zealand fails to win back Bledisloe Cup losing series in Australia 1-2. $3^{\text {rd }}$ test marred by allegations of deliberate food poisoning

New Zealand makes successful centenary tour of Wales, winning all their games and relieving the bitterness between the 2 nations.

Springbok tour of New Zealand. All Blacks win series 2-1. Tour marred by protest violence. Two matches are cancelled on Police advice

New Zealand wins back Bledisloe Cup from Australia 2-1. Maori tour Wales

Lions tour New Zealand. All Blacks win series 4-0. Depleted New Zealand team tours Scotland and England, not winning any of the tests. 
"The Baby Blacks" defeat France. New Zealand loses Bledisloe Cup to Australia at home. New Zealand draw series in France, losing the Nantes test in a brutal violent game.

First World Cup hosted by New Zealand and Australia is won by New Zealand. Bledisloe Cup won by All Blacks in Australia

Wales tour New Zealand. The All Blacks destroy Wales in both tests. New Zealand tours Australia and successfully defends the Bledisloe Cup in an undefeated tour.

Argentina, France and Australia tour New Zealand. The All Blacks win all their games convincingly. New Zealand makes an undefeated tour of Ireland and Wales.

Four All Blacks switch to professional Rugby League. Grand Slam European champions Scotland tour New Zealand. All Blacks win both tests but the $2^{\text {nd }}$ test proves to be the last for inspirational captain Wayne Shelford who is dropped in controversial circumstances. New Zealand successfully defends the Bledisloe Cup but is beaten in the $3^{\text {rd }}$ test by Australia, their first loss in 51 games. New Zealand tours France and wins both tests in convincing style.

New Zealand draws Bledisloe series with Australia. 2nd World Cup hosted in Britain and France with the All Blacks beaten by Australia in the semi-final.

New Zealand Rugby Union celebrates its centenary with a three match series against a World XV. The All Blacks win 2-1. Ireland tour New Zealand and almost beat the All Blacks in the $1^{\text {st }}$ test. New Zealand tours Australia and South Africa, losing the Bledisloe Cup series 1-2 but defeating South Africa in Ellis Park in the Springboks first match back from isolation.

Lions tour New Zealand. The All Blacks win a close series 2-1. New Zealand wins back the Bledisloe Cup from Australia but loses to England on their tour of England and Scotland.

France tour New Zealand and defeat the All Blacks 2-0 in series. South Africa tour New Zealand with the All Blacks winning the series 2-0 with 1 draw. Australia wins back the Bledisloe Cup in Sydney despite $2^{\text {nd }}$ half fightback by the All Blacks. 
The third World Cup hosted by South Africa. All Blacks play an exciting attacking style which comes unstuck in their final loss to the Springboks amid allegations of food poisoning. On August 26 the International Rugby Board declared Rugby Union an "open" game and thus removed all restrictions on payments or benefits to those connected with the game. It did this because of a committee conclusion that to do so was the only way to end the hypocrisy and to keep control of rugby union. New Zealand wins back the Bledisloe Cup back. New Zealand tours Italy and France, beating the Italians and leveling the series with the French.

The inaugural year of the professional Super 12 championship featuring regional teams from South Africa, New Zealand and Australia and the Tri-Nations Championship featuring the same countries, which is won by the Blues and All Blacks respectively. The Bledisloe Cup is won by New Zealand. New Zealand tours and defeats South Africa for the first time in South Africa.

Super 12 won by the Blues. The Tri-Nations and Bledisloe Cup is won by New Zealand. All Blacks complete an undefeated tour of Ireland, Wales and Scotland

Canterbury Crusaders defeat the Blues in the Super 12 final to win the first of their three in a row finals. Despite crushing England in June New Zealand then proceeds to lose five tests on the trot to come last in the Tri-Nations and lose the Bledisloe Cup to Australia.

New Zealand destroy France in Wellington, win the Tri-Nations but lose the decider for the Bledisloe Cup. The fourth World Cup hosted by Wales has New Zealand installed as favourites but are upset in the semi-final by eventual runners-up France. New Zealand ends tournament in $4^{\text {th }}$ place after losing to South Africa. John Hart, All Black coach is vilified as he resigns his position.

New Zealand defeats Australia in Sydney in a game that is dubbed "Game of the century" and South Africa in Christchurch. All Blacks lose their way dropping their last 2 matches including a last minute loss to the Wallabies to give them the Bledisloe Cup and the TriNations. New Zealand loses $2^{\text {nd }}$ test to France in Marseilles.

Brumbies become the first non-New Zealand team to win the Super 12 when no New Zealand teams made the play offs. New Zealand defeat the Springboks home and away but lose both games to Australia with the Tri-Nations decider lost in the last minute. This 
loss undermines the confidence of coach Wayne Smith who is replaced by John Mitchell who takes the All lacks on an undefeated tour of Scotland, Ireland and Argentina.

Crusaders win the Super 12 with a $100 \%$ record. New Zealand win the Tri-Nations but again lose in the last minute to Australia for the Bledisloe Cup. Mitchell bloods inexperienced players in their tour to England France and Wales. New Zealand is stripped of the sub-hosting rights for the 2003 World Cup. The chairman, CEO and some of the Board is sacked and replaced.

Blues win Super 12. The All Blacks lose to England but win the Tri-Nations in style and become hot favorites to win the World cup in Australia but lose to Australia in the semifinals. England win the World Cup for the first time.

\section{Methodology}

\subsection{Research Sources}

Access to other literature was primarily via main abstracting sources, Index New Zealand, Index to New Zealand Periodicals and Newztext Plus, which is an index of New Zealand newspapers. These sources were consulted, using APAIS subject headings, to locate relevant periodical and newspaper articles with sufficient and appropriate content. They index a limited number of periodicals and newspapers with rugby content.

For academic articles on the subject, subject specific databases were searched: Ausport, Psycinfo, Sociological Abstracts, Sociological Collection and Sport Discus. Interdisciplinary databases were also searched: Project Muse, ProQuest, Ebscohost and Expanded Academic (InfoTrac Onefile). The researcher used the following key words and search terms from the Library of Congress Subject headings and mapped key terms to thesaurus entries and topic guides on each database where applicable and used them as free text searches.

- Sport

- Rugby-Union

- All Black

- Masculinity

- Identity 
- Nationalism

- Sports violence

- Psychology

- Racism

- Alcohol abuse

- Leadership

- Race relations

- Amateurism

- Professionalism

- Commercialism

Also consulted was the New Zealand National Bibliographic Database. These cover serials, books, theses and monographs.

\subsection{Evolution of rugby literature}

The format of Rugby literature has changed over time. While there were plenty of articles concerned with what had just been played and what was going to be played in the near future until the late 1980s there was little in terms of articles that take a wide look at a certain theme and try and place it in a contextual relevance to what was happening in the rugby world concerning New Zealand. Rather the key rugby writers of the time were employed to follow the All Blacks or their opposition on tour and a tour book would be produced in which all the action on and off the field would be relayed to the audience. It was also an opportunity for rugby writers to profess their views on particular themes and arguments they felt were pressing at the time. Of these Terry McLean was widely regarded and was referred to by his peers as "The Doyen", being recognised as the premier rugby authority in New Zealand. His passing in 2004 has left a huge void. Occasionally a great player had a biography written about them but as their life and rugby stories were ghosted by professional writers, the New Zealand Rugby Union seemed happy to believe that royalties had not been accepted by players. The situation toughened when various touring teams expressed amazement at the flouting of Amateur Regulations by the All Blacks, and scrutinisation became more intense from the mid 1980s onward. Graham Mourie, former All Black captain 1977-1982 was admired for announcing, after the publication of his biography, that he had accepted royalties and therefore was in breach of the regulations. Under severe pressure, the International Rugby Board relaxed its by-laws banning players from accepting royalties from books covering their career in 1986 which saw an increase in proliferation of the player biography/ autobiography. Now the players themselves were offering their own perspectives on pressing issues they experienced through their playing careers. Sometimes these views would be in conflict with rugby hierarchy or with views expressed by other notable authorities. While it 
may be fair to say that some of these "rugbiographies" did not reach great literary heights, their value is in the expressing of insights and attitudes upon themes that had a huge bearing on the shaping of rugby with New Zealand society. The rise of the "rugbiographies" coincided with the demise of the tour book, due partly to the advancement of media technology and saturation in the rugby book market. Newspaper reports with the match details became available almost instantaneously and the arrival of the internet with rugbyspecific websites provided commentary and post match comments from rugby writers and fans. Allied to this was the increasingly available television coverage of matches so the fans could see the play for themselves and relied comparatively less on the descriptive tomes of rugby reporters. These made the books written specifically on a tour redundant as by the time the book was available to the reader several months after the fact the interested public had already been inundated with reports and reviews of the tour.

This bibliography will focus primarily on New Zealand published material, however internationally published material will be included if it is readily available within New Zealand and if its main focus is on New Zealand rugby themes. Items that have been explored are:

- Books and chapters in books

- Periodical articles - Peer reviewed articles offer a scholastic perspective on the everchanging world of rugby.

- Theses - This material has not been covered sufficiently by existing tertiary resources and contain many studies reflecting upon rugby in New Zealand

- Magazine articles - some of New Zealand's popular magazines will have some insightful articles that are related to society and rugby.

- Newspaper articles.

For books and monographs, the subject headings usually did not allow specific descriptions beyond the generic "rugby-history", or "All Blacks (rugby team)", or "Rugby Union football New Zealand History". Many of the books under consideration had no index; therefore it became necessary for the researcher to read them all. From the late 1960s to the early 1980s the tour book was still the main vehicle to chronicle 
attempt to analyse and comment upon events or incidents so the reader may be able to place them in context to their environment.

\subsection{Delimitations/Limitations}

The primary delimitation of the bibliography is the exclusion of articles concerning the 1981 Springbok tour of New Zealand, except in cases where they a) specifically consider the other topics under consideration or b) discuss the 1981 Springbok tour in relation to other tours. This subject area has been covered by Sharon Saunders' The 1981 Springbok tour of New Zealand: an annotated bibliography (2000). This bibliography is complimentary to Saunders' bibliography. In addition articles and books concerned solely with match results and descriptions will not be included, unless they have bearing on the topics under consideration. Some literature that has dealt primarily with protests has been excluded, as they are more "protest literature" than rugby literature though some of the scope of these articles may share common ground. The primary limitation is that due to the wide variation of newspapers, it is not possible to cover all literature in such a wide field as Rugby. Therefore only major dailies were searched.

TV and sound archives were considered but rejected for reasons of access would attract costs. However this is something that can be explored at a later date. Newspaper articles that offer an evaluative observation on the aforementioned themes have been considered but otherwise descriptive accounts of the matches are well served by almanacs, historical accounts and Encyclopedias. Promotional and advertising material has been excluded.

\subsection{Arrangement}

The layout of the bibliography is as follows:

\section{Main Body}

The main body consists of individually numbered entries. Each entry consists of:

- An individual entry number in bold

- A full citation using Chicago A citation style, as determined by the Chicago Manual of Style $14^{\text {th }}$ ed. (Chicago: University of Chicago, 1993)

- An annotation briefly summarizing the content, scope and purpose of each item 


\section{Citations}

The bibliography is in author order. All citations have been arranged chronologically within each author.

This ensures that the bibliography continues to be simple to use over time, where as subject and classification terms might change.

Because of the general nature of many of the rugby books it became impossible to pigeon hole exactly what theme each particular book was concerned with, mainly because they dealt in equal parts with a wide variety of themes. It was also felt that individual authors tended to focus and follow up on similar themes.

\subsection{The need for bibliographic coverage}

This bibliography includes relevant material offering comment on the history and current situation of New Zealand rugby. The bibliography highlights the thematic avenues of study while differences of opinions between authors writing on the same topics are noted and compared. Literature from many sources covering the 37-year period 1967-2003 (incl.) has been assessed for discussion and cross-referencing. Citations follow author alphabetical order in the first instance, then chronologically therein. This allows researchers to follow progressive arguments or studies by individual authorities. A General Index lists the annotated items.

The user groups most likely to find this bibliography useful include

- Researchers and rugby historians

- Journalists

- Interested rugby fans

\subsection{Glossary of Main Terms}

Australian Rugby Union

CABTA

Citizens All Black Tour Association

CARE

Citizens Association for Racial Equality

FIRA Federation Internationale de Rugby Amateur

HART Halt All Racist Tours

Lions Representatives of England, Wales, Scotland and Ireland that traditionally tour rugby strongholds in the Southern Hemisphere

NZRFU New Zealand Rugby Football Union

SANZAR South Africa, New Zealand and Australian Rugby alliance 
SARB South African Rugby Board

Springboks Nickname of the South African rugby team

Tri-colors Nick-name of the French rugby team

Wallabies Nick-name of the Australian rugby team

\section{Bibliography of Introduction}

Bickerstaff, T 1998. Heroes and Villains. South Auckland: Hilton Valentine.

Chester, R.H. and N.A.C. McMillan. 1981. The Encyclopedia of New Zealand Rugby. Auckland: Moa Publications

Chester, R.H. and N.A.C. McMillan. 1987. The Encyclopedia of New Zealand Rugby. $2^{\text {nd }}$ ed. Auckland: Moa Publications.

Chester, R.H and McMillan, N.A.C. 1990. The Visitors. Auckland: Moa Publications

Chester, R.H. and N.A.C. McMillan. 2000. Men in Black. Auckland: Hodder Moa Beckett.

Chicago Manual of Style 1993 Chicago: University of Chicago Press

Hope, H. 2002. Whose All Blacks? Media, Culture \& Society 24 (2): 235-253

Jenkins, J.M. 1998. A Rugby Compendium. An Authoritative Guide to the Literature of Rugby Union. Boston Spa, West Yorkshire: British Library.

Kay, R. 1992. The Influence of Sport on Social Values. An examination of persisting and Changing themes in the Depiction of New Zealand Rugby Union Football c. 1940's-1990's with particular reference to the Publications of T.P. McLean. University of Waikato.

King, M. 2003. The Penguin History of New Zealand Auckland: Penguin Books.

Laidlaw, C. 1973. Mud in Your Eye. A Worms Eye View of the Changing World of Rugby. Wellington: Reed

McLaren, D. 1990. A Handbook of Rugby Literature. Dunedin: D. McLaren 
McLean, T.P. 1959. Kings of Rugby: The British Lions' 1959 tour of New Zealand. Wellington: A. H. \& W. Reed.

McLean, T.P. 1968 All Black Magic: the 1967 tour. Wellington: Reed

McLean, T.P. 1971. Lions Rampant: the Lions Tour in New Zealand. Wellington: Reed

McLean, T.P. 1973 They missed the Bus: Kirkpatrick's All Blacks of 1972/3 Wellington: Reed.

McLean, T.P. 1975. All Blacks Come Back: Terry McLean Looks at New Zealand and World Rugby.

Wellington: Reed.

Maclean, M. 2000. Football as social critique: Protest movements, rugby and history in Aotearoa, New

Zealand. The International journal of the history of sport 17 (2/3)

Nauright, J. 1991. Sport, Manhood and Empire: British Responses to the New Zealand Tour of 1905 The International Journal of the History of Sport 8 (1): 239-255

Palenski, R., R.H. Chester, and N.A.C. McMillan. 1998. The Encyclopedia of New Zealand Rugby. $3^{\text {rd }}$ ed. Auckland: Hodder Moa Beckett.

Palenski, R. 2003. Century in Black Auckland: Hodder Moa Beckett.

Park, J. 2000. "The worst hassle is you cant play rugby" Haemophilia and masculinity in New Zealand Current Anthropology 41(3): 443- 454

Smith, S. 1999. The Union Game. A Rugby History London: BBC

Swan, A.C. 1948. The History of New Zealand Rugby Football Union. Wellington: Reed.

Thomas, P. 2003. A Whole New Ball Game Auckland: Hodder Moa Beckett.

Vincent, G. 1997. 'A Tendency to Roughness': Anti-Heroic Representations of New Zealand Rugby

Football, 1890-1914 Sporting Traditions 14(1): 91-110

Vincent, G. 1998 Practical Imperialism: The Anglo-Welsh Rugby Tour of New Zealand, 1908 The International Journal of the History of Sport 15(1): 123-140 


\section{Bibliography:}

A1

AGB McNair: "Tour Questions." New Zealand Listener 110, no. 2366 (22 June 1985): p 14-15.

The New Zealand Listener commissioned a comprehensive survey conducted by AGB:McNair on New Zealanders attitude towards the issues arising from the NZRFU's decision to proceed with the tour of South Africa in 1985 . This poll also explored the reasons why people hold their views.

A2

Andrewes, Frazer. "Demonstrable Virility: Images of Masculinity in the 1956 Springbok Rugby Tour of New Zealand." International Journal of the History of Sport 15, no. 2 (1998): 119-36.

Andrewes' analysis of the 1956 Springbok tour concentrates on the images of gender reflected in selected Auckland newspapers. The focus is on how masculinity and femininity were constructed and manipulated through representations of the body: exemplifying strong masculine traits while at the same time defining an arena characterised by its exclusion of women in all but menial roles. Much of the imagery produced a complex definition of gender.

Images of toughness and strength associated with on-field play or with training routines were emphasised by rugby reporters.

Masculinity was affirmed through the proper utilization of the body, through pushing it to extremes, through violent activity. While the level of violence exhibited during the tour became the subject of public speculation and debate the prevailing belief amongst many of the sports journalists seems to have been that rugby was a hard game played by hard men and a degree of violence was to be expected in such circumstances: within the controlled and strictly demarcated territory of the sports arena, violence had its place.

Kevin Skinner's exploits (physically intimidating the Springboks) are seen as heroic retribution. Questions of violence were an issue throughout the tour but were commonly rationalized in the discourse. Many of the press reports chose to highlight the courage individual players demonstrated by their determination to serve the team. Other players gained kudos in the press for potentially endangering their own bodies for the sake of their team.

Construction of women in the print media during the tour placed them as the antithetical other. Men concerned that women were invading their public space. The use of belittling humour proved a popular social weapon. The fact that men and the press found it necessary to single out women as a major irritant 
suggests that men were concerned at the increasing involvement women were having in those pursuits thought traditionally masculine.

\section{A3}

Ansley, Bruce. "Feilding's Rugby Blacks Protest." New Zealand Listener 110, no. 2366 (June 22 1985): $16-17$.

Feilding's Old Boys Black rugby team, despite their club voting in favour of the tour, showed their disapproval and mounted the country's only team protest of the debate, by forfeiting their matches. Their opposition and their own club reacted with a mixture of support and opposition.

\section{B1}

Barrow, Graeme. Up Front. Auckland: Heinemann, 1985.

With concern focussing on injuries and violence in the forwards, Barrow shows that these concerns are nothing new. There were concerns that the brutality of the forwards was endangering the popularity of the game and provides episodes of violence and skullduggery inspired by forward exchanges. Barrow provides a detailed history of the evolution of the New Zealand scrum and how the different scrum formations influenced the style of play of the All Blacks. He presents the case for the 2-3-2 scrum which New Zealand continued to play with for a number of years while the rest of the rugby world had moved on to variations of the 8 man scrum with a 3 man front row. The wing forward position that created so much controversy and criticism from the Home Unions is examined. New Zealand was at odds with the rest of the rugby world using 7 men only in the scrum while the $8^{\text {th }}$ man would act as a rover, putting the ball in the scrum and acting as an obstacle to the opposing half-back. This was regarded as being simply obstructionist and not in the spirit of the game by the rugby authorities from Britain. The major tours undertaken by the All Blacks are covered and how the effect of scrum domination by the opposition forced the New Zealanders to re-evaluate their own scrum in particularly the 1949 New Zealand tour of South Africa. 
Battersby, John. "New Zealand, Domestic Jurisdiction, and Apartheid, 1945-57." Journal of Imperial and Commonwealth History 24, no. 1 (1996): 101-17.

Battersby questions the emphasis of kinship and rugby as the impetus for New Zealand's attitudes to maintaining sporting contact with South Africa. Attitudes must be placed in the historical context of the post World War 2 period, the need for security and associated emphasis on protecting the rights of nations as sovereign states. New Zealand believes that the United Nations should give precedence to national sovereignty, over and above the rights of individuals, even where human rights abused occurred. This belief has implications in terms of New Zealand's government's attitude to apartheid in South Africa

\section{B3}

Betts, Marianne. "Rugby and Violence Theory to Be Studied." Dominion, 8 September 2001, news section, 3.

An 'anecdotal' link between violence against women and rugby is being studied by Damian O'Neil, a Massey University lecturer in sociology. His study found that when the All Blacks lost, the rate of male violence in the home increased.

B4

Bills, Peter. "Dark Destroyers." Rugby World, (August 1995): 36-38.

Bills pinpoints the game between New Zealand and England during the semi-finals of the 1995 World Cup Rugby Football Tournament as the epitome of difference between the playing styles of both teams. New Zealand's performance is seen as a reflection of the changes in rugby football towards a more attacking and adventurous approach. England relied on powerful forwards that dominate the set pieces while their flyhalf kicks for position whereas the New Zealanders played a more dynamic style that places an emphasis on athleticism of all 15 players which encourages a riskier but more attacking philosophy. 
B5

Bingham, Eugene. "Sometimes Winning Is Just Not Good Enough: Team the English Love to Hate." New Zealand Herald, 30 June 1998, A9.

Canvasses the opinions of rugby greats Andy Haden, Andy Dalton and Fred Allen about the current All Blacks team and their chances in the upcoming tri-nations competition. English Journalist Stephen Jones levels criticism at the All Blacks team and management since the advent of professionalism.

B6

Bingham, Eugene. "How Rugby Chiefs Dropped the Ball." New Zealand Herald, 27 July 2002, B5.

Dissects the Eichelbaum report and discusses and comments on the details revealed how the New Zealand Rugby Football Union lost the rights to sub-host the 2003 World Cup.

B7

Bingham, Eugene. "Rugby for Sale." New Zealand Herald, 25 Oct 2003, B1, B3.

Rugby being increasingly big business in New Zealand, Bingham considers whether the professional era has created a culture of greed within the game, particularly at the administrative level and discusses the efforts to make as much money as possible out of the World Cup competition by the International Rugby Board (IRB) and the current operations of the NZRFU.

B8

Bingham, Eugene. "Rugby for Sale : Part ii, Playing on the Breadline." New Zealand Herald, 27 Oct 2003, A20.

Bingham considers the way the professional era has divided the rugby world into rich and poor nations, resulting in the struggle faced by poor rugby unions, particularly the Pacific Island nations, to stay afloat and competing. The same divide between haves and have-nots is dividing New Zealand's provincial sides. Is the NZRFU is doing enough to support rugby in the Pacific or are they using the Pacific to strengthen New Zealand rugby. 
Booth, Douglas. "A Blight on Rugby : Letter to the Editor." Journal of Physical Education New Zealand 28, no. 3 (1995): 9-10.

Protests against the inclusion of the former South African rugby player and president of the South African Rugby Board Danie Craven in the International Rugby Hall of Fame due to his perceived support of the apartheid regime in South Africa.

\section{B10}

Boston, Jonathan. "Sport and South Africa- How Other Nations Handle the Issue." New Zealand International Review 2, no. 4 (1977): p 9.

New Zealand Prime Minister Sir Robert Muldoon continued to maintain that New Zealand's position was not unlike the stance taken by other western governments with regards to sporting contacts with South Africa during National's term of government. This article seeks to clarify the policies of some of New Zealand's major Commonwealth partners and allies with particular regard to Britain and Australia.

\section{B11}

Brooke, Robin. "The Game's Cleaner, but Let's Be Consistent with the Penalties." New Zealand Herald, 22 March 2003, D3

Rugby violence has improved hugely in the past decade as officials have clamped down on foul play. Brooke believes it is a welcome change and evidence that the sport has grown up. The game is far cleaner than it was, it is a much safer workplace than 10 years ago and offers a better advertisement for the sport for spectators. Television coverage has been partly responsible for the reduction in violence. Players are well aware they are under constant vigilance from cameras, referees and linesmen who have been given the power to rule on incidents. The concern is with the consistency of penalty. There is a list with recommended penalties for foul play, but the grey area or confusion comes when sentences vary. A central judicial panel might help, with a list of set penalties for offences. 


\section{B12}

Brooke, Zinzan \& Alex Veysey. Zinny. Auckland: Rugby Publishing, 1995.

Autobiography of former All Black number 8 Zinzan Brooke who talks about how he almost went over to Rugby League club Manly but with the understanding of Manly coach Graham Lowe stayed with Rugby Union in the chapter "Buck, me and Manly". He comments on the player drain from league poachings and how it impacted on the All Blacks in 1991 when they defended their crown in the 1991 World Cup in "Gravediggers". In the chapter "Come the revolution" he gives his insight on the beginnings of professionalism and the battle between the establishment backed by Rupert Murdochs News Limited and the World Rugby Corporation (WRC) which was backed by Kerry Packer. He notes the protestation from the British quarters clinging to amateurism.

\section{B13}

Broughton, Rahena. "Maori All Black Paul Quinn Retires." Tu Tangata, no. 17 (April -May 1984): p 4-5.

Quinn believes that Maori rugby must continue, helping keep rugby alive in New Zealand. He believes a Maori side can ease the pressure on the All Blacks by taking short "good will" tours. The New Zealanders' attitude in expecting their teams to win all the time is unreasonable, Quinn says, because players give up time and money for the game. If people want winners they must expect to pay for them. He believes that there is a place for professional rugby. Details Quinn's background and his dedication to rugby and his jobs that he did to fit around rugby.

\section{B14}

Brown, Bruce. "New Zealand and South Africa. A Study of Political Relations." New Zealand Listener 162, no. 1565 (October 10 1969): p 12-13.

The projected All Black tour of South Africa in 1970 has focused attention on New Zealand's relationship with South Africa. In a study of political relations, Bruce Brown, Director of the New Zealand Institute of International Affairs, gives a personal view of what New Zealand's attitude towards South Africa should be. He looks at the question of race on the international stage and at international attitudes to South African policies. He gives a brief summary of New Zealand's position within the Commonwealth and United Nations with regards to apartheid. While acknowledging New Zealand's and South Africa share a 
"common life style" it is not necessarily conducive to our national interests. With the establishment of closer ties with the Pacific and Asia, our links with apartheid South Africa will not make that relationship any easier. He concludes that "we should regard our bi-lateral political relations with South Africa with the greatest caution. Not only are there moral arguments which would urge this course, there are cogent, practical political reasons also" (p13)

\section{B15}

Brown, Chris. John Gallagher - the Million Dollar Fullback. Auckland: Rugby Press, 1991.

Autobiography of John Gallagher, an English born Irishman who became an All Black and starred in the inaugural World Cup as a highly successful fullback. Details his early life in the United Kingdom, his decision to move to New Zealand where he joined the police force and played rugby for Wellington. His career spans from the amateur days through the increasingly commercially aware late 1980s and finally his decision to defect and play professional rugby league when he joined Leeds Rugby league and being heralded the best player in the world. Gallagher gives his comparisons of the two rival football codes. His New Zealand time coincided with the beginnings of the "browning" of New Zealand rugby with Wellington containing exciting polynesian talent. His career also coincided with the emergence of the prototype of the Super 12- the South Pacific Championship. Gallagher recounts his career with the All Blacks starting with his first All Black tour, to France 1986, and the triumph of the 1987 Rugby World Cup which began the latest period of absolute domination of New Zealand over the rest of the world. This domination continues with the woeful Welsh tour of New Zealand in 1988 and the unbeaten All Black tour of Australia 1988, through to the 1989 season which included tours from Argentina, France and the Bledisloe Cup encounter. Finally the tour to Wales and Ireland at the end of 1989 proves to be his final All Black appearance where Gallagher begins to weigh up his options and join the professional ranks.

\section{B16}

Buchanan, Tim. "Missionaries of Empire: 1905 All Black Tour." University of Canterbury, 1981.

A thesis submitted to Canterbury University in partial fulfilment of the requirements for the degree of Masters of Arts in History. The thesis looks at the 1905 tour to Great Britain, Ireland and France in terms of the political usage made by both New Zealand and British politicians, parading the virtues of colonial life and rugby used as the focal point of nationalism moderated by the apparently contradictory expression of support for the imperial connection. Buchanan argues that the rugby tourists were missionaries of empire, 
encouraging the Mother Country to a proper appreciation of the role yet to be played by the Empire in shaping the destiny of the world.

\title{
B17
}

Buckley, Micheal. "A Colour Line Affair" Race, Imperialism and Rugby Football Contacts between New Zealand and South Africa to 1950." University of Canterbury, 1996.

\begin{abstract}
A thesis presented for the degree of Master of Arts in History in the University of Canterbury. This thesis is an attempt to construct an alternative tradition of New Zealand and South African rugby football contacts to 1950 . It examines the wider social conditions of such contacts, unlike the existing plethora of rugbycentred chronicles of matches, tours, and sporting personalities that made up rugby literature of the time. Rugby tours between New Zealand and South Africa before 1950 raised questions over the relationship between sport, race and imperialism. The manner that rugby reflected the divergent racial traditions in both societies thus challenges the cliche that sport is separate from wider social and political considerations. The chapters correlate with the New Zealand and South African rugby exchanges of 1921, 1928, 1937 and 1949. They are dominated by the themes of race relations and sporting imperialism, which forms the context of the tours.
\end{abstract}

\section{B18}

Butcher, Margot. "When Heroes Fall." New Zealand Sport Monthly, no. 84 (1999): 18-29.

Considers media stories in 1998-1999 about prominent sportspeople misbehaving publicly. Professionalism has impacted on the players and there has been a shift in attitude of the general public towards sports stars. Sports administrators to steer players away from trouble. Rugby players Tony Coughlan and Craig Innes discuss unsavoury incidents off the field they have been involved in.

\section{B19}

Butcher, Margot. "What Is Maori? Who Is Pakeha?" North and South, [n.s] (August 2003): 36-47.

Refers to the selection of Christian Cullen in the New Zealand Maori rugby team-which surprised the public who were ignorant of his Maori heritage. This is discussed in the context of how other sports select Maori teams. 
C1

Calder, Peter. "War Dance over Haka." New Zealand Herald, 27 Jan 2001, I1.

Discusses the haka, particularly the 'Ka Mate!' version performed by the All Blacks, and its place in New Zealand rugby and culture.

\section{C2}

Cameron, D. J. (Donald John). Rugby Triumphant : The All Blacks in Australia and Wales. Auckland: Hodder and Stoughton, 1981.

Cameron looks at the year 1980 and how New Zealand bounced back from the disappointments of their 1-2 series loss to the Wallabies to an unbeaten tour of Wales to celebrate the Welsh Rugby Union centenary. Cameron praises the style of the Wallabies and All Blacks which was more important than the results, escaping from the toils of safety-first, win at all costs, ten-man rugby. Chapter 11 "Welshness" looks back at the often tempestuous rivalry between New Zealand and Wales including how each nation regards the other, and the journalistic jousting between the media from both nations. Cameron recounts his experiences as a traveller within Wales in an attempt to understand Welshness to compliment his understanding of "kiwiness". He compares New Zealand and Welsh rugby influences on their society. The tour was a success in that it buries past grievances and bitterness and the rivalry was kept on the football field. Wales, the Welsh and the All Blacks buried the past ills and the tour turned the two nations back to a healthy respectful relationship.

C3

Cameron, D J. "Media Offside Says Mr Don." New Zealand Herald, 10 July 1982, section 1, 1.

Chairman of the Auckland Rugby Union Ron Don counters assertions from Parliamentary Under-Secretary for Recreation and Sport Mr GWF Thompson that the 1981 Springbok tour of New Zealand had resulted in diminution of support and esteem for rugby. Don claims that rugby overcame propaganda and distortion from anti-rugby media. 
C4

Cameron, D J. "Goalposts Move for Rugby Union." New Zealand Herald, 25 November 1994, section $1,9$.

Inappropriate administration by the NZRFU is blamed for the sidelining of rugby by a disaffected public and the many problems assaulting its image such as violence and declining player participation in rugby.

\section{C5}

Cameron, D J. "Rugby's Black Book Vital in Stamping out Violence." New Zealand Herald, 30 Aug 1997, A21.

Cameron scrutinises the disciplinary process administered by the NZRFU.

\section{C6}

Cameron, D J. "Latest Chapter in Old Story." New Zealand Herald, 13 February 1999, C7.

Cameron compares the Keith Murdoch and Norm Hewitt incidents. Murdoch, a notorious hard man was sent home from the 1972-73 tour of Britain, Ireland and France for assaulting a security guard. Hewitt became drunk and crashed through the glass plate of a house in Queenstown in 1999. Both had problems with alcohol. Cameron laments that the support for Hewitt was not available to Murdoch. Cameron remembers there have always been larrikins and asks the question of whether the world of commercial rugby put too much high pressure on immature young men who suddenly find themselves with a lot of money and a lot of spare time.

\section{C7}

Cameron, Don. "Decline and Fall of 15 Kiwi Icons." New Zealand Herald, 13 Nov 1999, A17.

Given the public's vitriolic reaction to the failure of the All Blacks to win the 1999 Rugby World Cup, Cameron speculates the reasons for this bitterness that led to the vilification of the players but with particular vindictiveness towards All Black coach John Hart. Media hype that fuelled public expectation 
and a disregard towards the All Black opponents intensified the extreme disappointment of the New Zealand public.

\section{C8}

Campbell, Gordon. "Frontline Coverage." New Zealand Listener 110, no. 2366 (June 22 1985): p 22, 24

The media plans to cover the proposed tour of South Africa 1985 was described as "three concentric circles with rugby in the middle." Games coverage being the first circle, news about the teams' activities off the field and tour related events. The third is seen as the current affairs team, which faces difficulty from South African officials. Those wanting to cover political events have to state their intentions when applying for visas. Investigates opinion polls on tour coverage and examines the NZBC legal and moral obligations to follow the tour.

\section{C9}

Campbell, Gordon. "Judgement." New Zealand Listener 110, no. 2375 (August 24 1985): p 14-16.

An examination of the New Zealand High Court's controversial decision to grant an injunction against the 1985 All Black tour to South Africa. The theme underlying the entire proceedings is that Rugby Union councillors, like protestors, can be brought to justice for their actions.

\section{C10}

Campbell, Gordon. "Passionate Player." New Zealand Listener 110, no. 2375 (August 24 1985): p 16.

Philip Recordon, plaintiff in the case to stop the All Blacks from touring South Africa hates apartheid but loves rugby. The article looks at his sporting and professional background and the mixed reaction from people to his role in proceedings. 


\section{C11}

Campbell, Gordon (ed). "Is Rugby Dying?" New Zealand Listener 110, no. 2367 (June 29 1985): p 22-

23.

Once rugby ruled as the sport of schoolboys, now with the sport being tarnished by controversies over the Springbok tour and rugby injuries the Listener organised a survey of every secondary school in the country with male pupils to find out "is rugby dying?"

$54 \%$ of secondary schools reported a decline over the last 5 years. Other reasons for the decline are given as the growing availability of other sports like soccer and basketball. While some pockets in NZ still regards rugby as supreme in the urban areas there has been a marked decline in the game's popularity. Looks at how dangerous rugby is. While the Springbok tour has done school rugby no good, in the areas most affected by the tours, the decline in rugby had set in beforehand. There are signs that the rugby authorities are starting to "reverse the policy of benign neglect" ( 123 ) with new national tournaments starting. The future of rugby seems to be determined by events beyond the control of rugby, such as the time needed to be put in to rugby by players and administrators.

\section{C12}

Chu, Michael M L \& Sarah I Leberman, Bruce L Howe, Dan G Bachor. "The Black Ferns: The Experiences of New Zealand's Elite Women Rugby Players." Journal of Sport Behavior 26, no. 2 (2003): 109-20.

The purpose of this study was to gain insight into the experiences of the New Zealand Women's Rugby Team, the "Black Ferns". Data were collected via semi-structured interviews on 23 Black Ferns. The authors discuss the motivations of the women to start playing rugby, as well as those factors that facilitated their continued involvement in the sport. In addition, the players' perceptions of participating in a strongly male dominated sport were identified. The Black Ferns started playing rugby for two main reasons: the physical nature of the sport, and because their friends played. The participants also offered two main reasons for continuing to play: enjoyment, and the challenge. The players expressed divided opinions about competing in what has traditionally been a predominantly male sport. The implications of these findings are important for administrators and those wishing to promote women's rugby. 


\section{C13}

Crawford, Scott A. G. M. "New Zealand Rugby: Vigorous, Violent and Vicious?" Review of Sport and Leisure 3, no. 1 (1978): 64-84.

Discusses key readings on aggression and violence which indicates that violent acts are common characteristics in body contact sports. Takes a look at the role of rugby in New Zealand society and compares it to other nations and comes to the conclusion that the level of rugby violence has deteriorated to a disconcerting level.

\section{C14}

Crawford, Scott A. G. M. "The Game of 'Glory and Hard Knocks': A Study of the Interpenetration of Rugby and New Zealand Society." Journal of Popular Culture 19, no. 2 (1985): 76-91.

Character of a nation as far as New Zealand is concerned has been more sharply delineated in sport tan in any other sphere of cultural activity. Crawford argues that the intense following for rugby made possible in 19th century colonial New Zealand "a new sense of belonging, a ritualistic involvement in a larger group". Middle class administrational influence used rugby to inculcate moral values, masculine character training, safety valve for dangerous passions and an agent of reconciliation between classes. Despite some criticisms of the game by some as "dirty fighting club" and "rough and tumble hoodlum amusement" the protagonists proclaimed rugby would "make a man of you". Early years of rugby in New Zealand were influential in shaping the style and strategy of New Zealand rugby. Describes the factors that made rugby a popular egalitarian activity as rugby providing an attractive social identity in an era of economic depression and social disquiet. Players communicated their identity through their rugby uniforms and rugby was viewed as a symbolic representation of the masculine lifestyle of the time. Modern sociopsychological theorising models are worth examining in understanding the participation and spectator appeal of rugby. The 1880s saw the evolution of second generation of New Zealanders express feelings of self respect. Rugby provided means to communicate common experiences and shared meanings and is seen as national cult and secular religion in contemporary New Zealand. There was a reverence of ordinary men doing extraordinary things. Greg McGee's play Foreskins Lament gives a penetrating analysis of New Zealand society and its values. 


\section{C15}

Crawford, Scott A. G. M. "Rugby in Contemporary New Zealand." Journal of Sport \& Social Issues 12, no. 2 (1988): 108-21.

This essay describes the socio-historical background of New Zealand rugby from its British origins in the middle of the nineteenth century up to present and examines the great importance of the game within New Zealand society. The paper examines the events leading up to the disorder surrounding the 1981 rugby visit to New Zealand by the South African team and the controversial 1985 decision by the New Zealand Rugby Football Union to decline to send a national touring team to play in South Africa. The concluding section indicates that the complex issue of sporting relations with South Africa has still not been satisfactorily resolved.

\section{C16}

Crean, Mike (and others). "Divided Nation." The Press, 14 July 2001, weekend section, 1-13.

Outlines the political situation which spurred protestors to demonstrate against the 1981 Springbok rugby tour of New Zealand and backgrounds the history of the anti-tour movement in New Zealand and describes the impact the violence which emerged from the protests, had on New Zealand society. Includes interviews with Matt Conway, Erin Baker, Howard Keene, Marian Hobbs and Rod Donald who were protestors and conversely describes the police perspective and how the tour changed the nature of policing in New Zealand including John Reilly, Bob Mather and Sam Cleland who were police officers at the time. Former All Blacks who played during the tour offer their perspective, as does the only non-white member of the Springbok team, Errol Tobias. Dissects the irony of the justification pro-tour supporters used in 1981 that politics should never be involved in sport. Reports on the positive impact the anti-tour protests of 1981 had in South Africa to help disestablish apartheid while expressing the opinion of pro-tour supporter Jamie Douglas and Clive Lind discusses the impact the tour had in Southland.

D1

David, Gabriel Raphael. Rugby and Be Damned. Wellington: Hicks, Smith, 1970.

This is the story of the 1970 All Black tour of South Africa. In "How it all started- or nearly didn't" presents the lead up to the tour in the face of mounting pressure from political and anti-tour groups and notes the increasingly influential Pan African groups. In chapter 4 entitled "The race problem" the 
author gives his opinion on the policy of apartheid in South Africa and where it may lead, lending empathy to the white minority.

\section{D2}

De Jong, Piet. "Kicking and Struggling into the Twentieth Century : Making Sense of New Zealand Rugby." Sites: A Journal for Radical Perspectives on Culture, no. 12 (1986): 29-42.

Analyses the development of representative rugby in New Zealand in terms of large scale changes to society, and struggles between groups involved with the sport. The institutionalisation of rugby in the late nineteenth century reflects the value that participation in sport should be for honour not money and looks at technological changes which made the game ripe for commercialisation. Examines evidence of the ensuing conflict between players and administrators in the biographical accounts of some of New Zealand's leading players, including George Nepia and Don Clarke.

D3

De Lacy, Hugh. "Sharper Focus for Professional Rugby." MG Business 123, no. 5365 (19 February 2001): 4-7.

Talks about the philosophy of the NZRFU now that rugby is a professional code and discusses plans for its annual income and tabulates its source of revenue.

\section{D4}

Dennison, Scott. "'Tour of the Decade'? New Zealand-South African Rugby Relations 1985-86." Massey University, 2000.

A thesis presented in partial fulfilment of the requirements for the degree of Master of Arts in History at Massey University. The thesis attempts to make an historical enquiry into the cancelled All Black tour to South Africa in 1985 and the rebel Cavaliers' tour that followed. It looks to answer a number of questions such as why did the NZRFU abandon the 1985 All Black tour to South Africa? It looks at the importance of factors such as Parliament's opposition to the tour, international condemnation from international sporting bodies, opposition from anti-tour groups within New Zealand, the legal challenge and 
potential backlash against rugby, in prompting the NZRFU's decision to call off the tour. The thesis also examines why there was an unsanctioned tour of South Africa in 1986. It seeks an understanding of why players risked a lifetime ban from rugby or from All Black selection for the sake of an unofficial series against the Springboks, and if large cash payments were made to players to tour South Africa. Divided into 6 chapters, chapter 1 looks over the controversies that have dogged New Zealand-South Africa rugby relationship from 1900-1984. Chapter 2 provides a chronological account of events surrounding the South African Rugby Board's (SARB) invitation to the NZRFU to send a team to South Africa, looking at arguments for and against touring the Republic and analyses the reaction to the NZRFU's decision to accept the SARBs decision. Chapter 3 focuses on the legal battles that led to the cancellation while chapter 4 provides a history of the Cavaliers and chapter 5 examines the immediate consequences of the Cavaliers tour on the players involved. Chapter 6 looks at the impact of the cancelled 1985 tour on rugby more generally and discusses rugby's relationship with the Government following the Cavaliers tour that followed and identifies the beneficial and detrimental effects the tour had on New Zealand and international rugby. It also looks at the violent episodes that peppered the matches in South Africa.

\section{D5}

Devlin, Martin. "Its Only My Opinion But..." NZ Rugby World, June 2002, 18.

Devlin explains the value of talkback radio as a release or safety valve for public reaction to rugby.

D6

Dixon, Greg. "Rugby, Beer and Young Males : A Devil's Brew." New Zealand Herald, 13 February 1999, A15.

Considers the relationship between sport (particularly rugby) and alcohol consumption following an incident involving All Black Norm Hewitt. Talks with sports commentator Murray Deaker, University of Otago sports sociologist Dr Steven Jackson, and Ian MacEwan of the Alcohol Advisory Council. Deaker speculates that with rugby, alcohol has always been a partner. Alcohol was also a bane on Keith Murdoch and other sports stars. Traditional attitude was "play hard then drink like a man". Sean Fitzpatrick is unhappy with the media criticising rugby in the wake of the Hewitt incident, making the point that many All Blacks are non drinkers. Sponsorship of rugby by breweries and hotels make for a contradiction. 
Responsibility also lies with the Rugby Union over the Hewitt incident. According to Moffett (the NZRFU $\mathrm{CEO})$ players are provided with education, advice and group counselling on alcohol.

D7

Dixon, Greg. "A Game of Two Halves." New Zealand Herald, 1 July 2000, I1-2.

Investigates concerns over the state of schoolboy rugby in Auckland, particularly the suggestion that certain schools are recruiting and poaching players from other teams. Notes the suggestion that a concentration on big, strong players, particular faster maturing Polynesians, is having a detrimental effect on the game. The competitiveness on the field has changed ethics of schoolboy rugby where the three pillars of schoolboy rugby- passion, tradition and fair play are being eroded by strong teams building on imports from weak teams. Big tackles and giant players are encouraged but smaller players and ball skills are being lost. Talks with Chris Saunders, principal of Onehunga High School and president of the Auckland Secondary Schools Heads Association.

D8

Douglas, Tom. "Go out There and Die? Not Any More!" New Zealand Listener 77, no. 1823

(November 2 1974): p 46-47.

Douglas looks at the problems facing the game in New Zealand and gives an anxious eye towards the Irish tour. He concludes that gone are the days when the philosophy was "Go out there and die for New Zealand." All Black coach JJ Stewart described as a different breed of coach who was an acute analyser and would think outside the square, while having broad academic interests. He emphasised skill and tactics as opposed to raw aggression and confrontation. 
Easterbrook, Mark. Rugby, Masculinity and National Identity : The Use of Rugby as a Signifier in New Zealand Television Advertising: University of Auckland, 2001.

A thesis submitted to the University of Auckland in partial fulfilment of the requirements for the degree of Master of Arts in Film, Television and Media Studies. Easterbrook examines the importance of rugby union to the cultural hegemony in New Zealand, seeking to explore why rugby has become an important masculine identity in New Zealand culture. The medium through which this explored is television advertising with specific attention on 2 periods: the months leading up to and during the 1999 World Cup and the 2001 season. It contrasts the differences in the way the advertisments represent rugby to New Zealanders. The thesis gives a compelling argument that this difference is a consequence of the failure to win the 1999 World Cup and the neo-traditionalist overhaul rugby faced in 2000 as a result.

The thesis illustrates how a hegemonic system works to accommodate change in order to maintain itself. The ways in which the hegemonic dominance of New Zealand masculine identity are maintained through a period of identity crisis is highlighted through comparing and contrasting television advertisements from the pre and post 1999 World Cup periods. Includes a chapter exploring the social and cultural importance of rugby in New Zealand, and looks at the transformation of rugby as an amateur sport into big business.

E2

Editor. "How It All Slipped from Our Grasp." New Zealand Herald, 24 July 2002, Section 1, 13.

Editorial that looks at the details of how the NZRFU lost the rights to sub-host the 2003 World Cup- the crucial decisions and actions that led to the loss from the report of the independent Eichelbaum inquiry. Examined in detail is the reluctance of the NZRFU in grasping the seriousness of Australia's threat to strip them of their sub-hosting rights, the issue of "clean" stadia and the rising costs to be absorbed by the host unions. 
Fatiolofa, Peter \& Phil Gifford. Fats : Peter Fatiolofa and the Manu Samoa Story. Auckland: Rugby Publishing, 1996.

Story of the Ponsonby, Auckland and Samoan prop who was tipped by many to become an All Black. He describes breaking into the New Zealand rugby scene as a young Polynesian and after failing to achieve All Black status he became one of the pillars of the Western Samoan emergence as a genuine rugby power.

F2

Finn, Brian. "To the Victor the Spoils." NZ Rugby World, June 2002, 28-35.

Finn talks to Australian Rugby boss John O'Neill, about trans-tasman relations and the Australian version of the 2003 Cup-hosting saga which lays the blame on the NZRFU's reluctance to accept their subhosting status.

F3

Fitzpatrick, Sean. Turning Point- the Making of a Captain. Auckland: Penguin, 1998.

Sequel to "Fronting Up" (O4) All Black captain Fitzpatrick backgrounds the change from amateurism to fully fledged professional while he was a player and gives his perspective on the News Limited and World Rugby Corporation battle for the ownership of professional rugby. Fitzpatrick recounts his battle with Johan Le Roux who bites his ear in the second test against South Africa in 1994. The Super 12 and Tri Nations series of 1996 and 1997 are covered in detail. 
Foged, Jon. The Impact of Professionalism on the Rugby Industry : A Study of New Zealand and Australia. University of Auckland, 1999.

A thesis submitted to the University of Auckland in partial fulfilment of the requirements for the degree of Master of Commerce in International Business. The rugby industry's shift to professionalism is examined as a major environmental change for industry participants. The thesis assesses the different theories of strategic choice and environmental determinism. Theories of environmental determinism and strategic choice have previously been conceptualised as mutually exclusive and the primary objective of this study was to test a framework that integrated these theories.

Data was obtained from 304 responses from rugby organisations in New Zealand and Australia. It was found that both the environment and management were able to exert some influence over an organisation's behaviour. Organisations could simultaneously be exposed to low levels of inertia (strategic choice factors) and high levels of inertia (determinism factors) in the environment. Secondly, it was found there was a significant difference between organisational types and the collective levels of choice and determinism. Lastly, it was found organisations with high levels of professionalism had higher levels of choice and determinism than organisations with low levels of professionalism

F5

Fox, Grant. The Game the Goal: The Grant Fox Story/with Alex Veysey. Auckland: Rugby Press, 1992.

The record point scorer in New Zealand rugby, Fox recalls his days with the mighty Auckland team of the 1980s and early 1990s. Describes the epic Ranfurly shield challenge in Christchurch 1985. Fox was a permanent fixture in the All Black line-up during 1987-1991.

Contains descriptions of the 1986 Cavaliers tour and All Black games from 1986 to 1991 including the inaugural World Cup in 1987 and the ill fated World Cup 1991 and provides a players perspective of the disintegrating relationship between All Black coaches John Hart and Alex Wyllie. Compares other great five eighths he has faced and selects a "world XV". Busts the rumours about the supposed fight he had with captain Wayne "Buck" Shelford that led to the latter's dropping from the All Blacks. 
Francis, Jayne. "What Is Barbaric Behaviour?" New Zealand Law Journal (April 1997): 121-22.

Asks where the limits of consent lie in sport. Considers New Zealand and United Kingdom incidents of rugby violence, and the responses of the respective courts to these.

F7

Frost, David. The All Blacks 1967 Tour of the British Isles and France. London \& Christchurch: Wolfe Publishing \& Whitcombe \& Tombs, 1968.

Although seen as a great tour there were still problems. Frost believes the Meads sending off affair were mishandled by both Charlie Saxton the manager and Fred Allen the coach. There were different interpretations of the laws with Refs in Britain stricter at the lineout and New Zealand referees are stricter with players lying on the ball. Praise was given for the side as they tried at all to make the fullest possible use of all fifteen members of the side. They did not give up attacking just because they found themselves faced by a defence that at first appeared impenetrable.

The 1967 All Blacks showed that there was no need to be constantly searching for second phase possession. A high proportion of their tries were scored by the backs direct from set pieces. In the chapter Verdict on Meads Frost goes over what occurred leading up to and what resulted from the sending off of Meads against Scotland.

G1

Galvan, Michael Hugh. "Factors Affecting the Dropout of Adult Rugby Players in the Christchurch Metropolitan Area." Massey University, 2000.

This study investigated the reasons eight 20-25 year old males from 9 clubs in the Christchurch metropolitan area discontinued their involvement with rugby. From interviews with rugby dropouts, data was subjected to content analysis to identify common themes. Key findings indicated a number of reasons subjects dropped out of rugby, including "clash of jobs and tertiary studies", "burnout and in need of a break", "trying another sport", a lack of time to do other activities and interests", "injuries", and "coaches". The impact that coaches have on individuals was the most significant factor found. Subjects indicated a 
dislike for coaches who were "autocratic", "negative" and "poor communicators". The implications of these results indicate educating coaches about the influence they have and equipping them with the skills to meet players' needs could begin to decrease the number of adults dropping out of rugby.

G2

Gamble, Warren. "Abuse of Refs Crosses Line." New Zealand Herald, 24 August 2002, B2.

Talks to some of New Zealand's professional referees about their job and the increasing amount of abuse that rugby referees are being subjected to particularly from spectators.

G3

Gault, Ian. For the Record: The Allan Hewson Story. Auckland: Rugby Press, 1984.

Biography of the Wellington fullback who played against the 1981 Springboks despite the fact that his wife was strenuously opposed to the tour. Hewson in the chapter "Busting the Boks" makes the point that while he found apartheid abhorrent he earnestly defended his right to play rugby against anyone, and argued that rugby was helping break down some of the racial barriers in that country and rugby contact had done more than isolation would have.

In the chapter "To Allan, a key ring" he recounts the frustration of being an amateur when winning the player of the series award which was a car against the 1982 Wallabies. Unfortunately because of rules relating to amateurism the prize could not be awarded to an individual but rather it had to be awarded to his club Petone. Being an amateur he could not benefit tangibly from any awards.

In the chapter "Quid pro queue" Hewson offers his views on the 1983 David Lord proposal for a professional troupe. Hewson says that the threat of being outlawed from the amateur game for life was a sacrifice most seemed prepared to make in return for huge incomes of up to $\$ 250,000$ over a two year period. Compared to the $\$ 126$ per week for amateurs on tour it lead many in the All Blacks to seriously contemplate it. Though the idea lost momentum it opened the door for future proposals. The David Lord threat to the rugby establishment led to an increase in the weekly allowance to \$NZ182 per week. 
G4

Gaynor, Brian. "Kiwi Business Fumbles Ball of Opportunity." New Zealand Herald, 9 October 1999, E2.

Jonah Lomu and the All Blacks are hot items yet no kiwi business is using them to promote products in Europe. The commercial use of our rugby talent has not yet being realised to its potential.

G5

Gerritsen, John. "Brand New Game Plan." New Zealand Education Review 3, no. 19 (1998): 9-10.

Discusses how increasing professionalism is resulting in the development of partnerships between sporting bodies and academic institutions such as the New Zealand Rugby Football Academy at Massey University, the New Zealand Cricket Academy at Lincoln University and the Netball Institute of Canterbury at Aoraki Polytechnic.

G6

Gerritsen, John. "Where Money and Globalisation Meet Identity and Rugby." New Zealand Education Review 8, no. 41 (2003): 6-7.

Steve Jackson of the University of Otago talks about the commercialisation and globalisation of rugby; Tony Bruce and Fabrice Desmarais from the University of Waikato discuss their involvement with French and New Zealand rugby commentators as well as their contributions to perceptions of the sport and national identity and how the two concepts are infused with each other in New Zealand.

\section{G7}

Gifford, Phil \& Reid, Tony. "Weighing up the Heavies." New Zealand Listener 96, no. 2133 (1980): p 16-20.

Describes how the NZRFU is run and introduces the 18 Council members while getting their views on the South African tour planned for 1981. Includes Ivan Vodanovich, Noel Stanley, Bill Freeman, 
Waka Nathan, Paul Mitchell, Stuart Sharp, Ces Blazey, Tom Johnson, John Clifford, Bob Stuart, Ron Don, Peter Wild, Pat Gill, Pat Beaumont, Ray Harper, Russell Thomas

\section{G8}

Gifford, Phil. "A Man's Game." New Zealand Listener 104, no. 2267 (1983): p 50-53.

Gifford takes a look at social rugby, the seeds for "golden oldies" rugby. British critics argue that the kiwi "oldies" still take their rugby too seriously. Idiosyncracies of Golden Oldies rugby includes different coloured shorts depending on the players age. Some of the more senior players are allowed to play without being tackled. Illustrates the role of alcohol at the after match function.

G9

Gifford, Phil. "Professionalism : A Question of Money." Time International (New Zealand edition) 33, no. 23 (1989): 23-24.

Discusses compensation for loss of earnings while on rugby tours and mentions changes to the International Rugby Board (IRB) regulations on allowances. Considers the ethics of using players in advertising. Talks about proposals to collect revenue in a trust fund. Argues that the sport has evolved to such an extent that players deserve to make some financial compensation but ultimately it is the conservative IRB that needs to be convinced.

G10

Gifford, Phil. Smokin' Joe. Auckland: Rugby Press, 1990.

Biography of Joe Stanely, centre for Auckland and the All Blacks during the 1980s and early 1990s. Talks of his connection with Samoa and how Samoa has helped shape New Zealand rugby. Discusses the fight in Wales when with Andy Earl they were attacked by Welsh fans during the All Blacks 1989 tour. Provides match descriptions the All Blacks were involved in from 1986 to 1990. 


\section{G11}

Gifford, Phil. Grizz the Legend. Auckland: Rugby Press, 1991.

Biography of Alex Wyllie, player and coach of Canterbury and New Zealand. Regarded as a genuine hard man of rugby where violence was used when neccesary. The violent Lions- Canterbury match of 1971 is discussed in "Not a happy man to meet in the other side" where he and his team were labelled thugs. Wyllie contends that the Lions' manager Doug Smith persuaded the British press to write the match up as dirty. He gives his perspective on the Murdoch sending home during the 1972-73 tour in "Murdoch and the mafia" where he believes Murdoch, while capable of rowdy behaviour was unfairly maligned by the press. As a coach he describes the frustration of politics from behind the scenes from the NZRFU, some of whom wanted John Hart to coach the All Blacks. He gives his perspective on the decision to drop hero and captain Wayne "Buck" Shelford.

\section{G12}

Gifford, Phil. Mike Brewer : The Authorised Biography. Auckland: Rugby Publishing, 1995.

Biography of Mike Brewer All Black loose forward from 1986-1995 who made his debut as one of the "baby blacks." He expresses the dilemma facing New Zealand rugby: the threat from rugby league and no remuneration (of the official kind). He highlights the problem with some of his contemporary players who suffer from a 'me first, the team second' mentality. Brewer details his experiences of playing in Italy. Brewer opines that as the 21 st Century approaches rugby in New Zealand must learn the lessons that have seen some economic giants of the 1960s and 1970s crash and burn while more progressive corporates have prospered as they have been unafraid to change and the NZRFU needs to look at its situation the way any other corporate would. He gives his own model on professional set up in New Zealand including getting the provinces to make the decisions on individual payments to players, not the NZRFU. Marketing the game would fall under 4 headings: product and presentation; the laws; the media; and sponsorship.

\section{G13}

Gifford, Phil. Loyal: The Todd Blackadder Story. Auckland: Hodder Moa Beckett, 2001.

Gifford follows the career of popular Canterbury icon Todd Blackadder. From his early days with Nelson Bays to cementing his place in the Canterbury side. Takes a look at the rugby landscape from the 
early 1990s to 2001. Charts Blackadder's exploits from the NPC, the Super 12, his introduction into the All Blacks, his accession to the captaincy of the All Blacks in 2000 and he talks frankly about the temptations of playing overseas.

G14

Gifford, Phil. "We Could Be Buggered." NZ Rugby World, July 2001, 24.

Gifford looks at the possibility of a non-New Zealander coaching the All Blacks.

\section{G15}

Gifford, Phil. "Comprehensive Clean-out (and Not before Time)." NZ Rugby World, October 2002, 16.

Gifford criticises the NZRFU for what he sees as their incompetence and pig-headed conservatism and was not surprised that, when professionalism became a reality, they got it so wrong. In Jock Hobbs and Mike Eagle he sees newcomers to the board bringing some much needed improvement.

\section{G16}

Glasspool, Barry. One in the Eye. Cape Town: Howard Timmins, 1976.

The story of the 1976 All Black tour to South Africa from a South African perspective. The author gives a background on South African President Dr Hendrik Verwoerd's 1965 Loskop Dam speech which set out the Nationalist Government's opposition to the inclusion of Maoris in a New Zealand rugby team due to tour the Republic in 1967.

Initial criticisms of South African referees from New Zealand management centred on "appalling differences in interpretation" and the glaring lack of the "knowledge of the laws" later escalated to "dark, sinister mutterings about bias". Glasspool had sympathy for New Zealand over the refereeing but points the blame at the New Zealand Council which turned down the South African offer of neutral officials. Dr Craven was quick to deplore some of the attacks by New Zealand pressmen on South Africa. Unlike 
previous All Black teams, the 76ers had no 'meanies' or muscle men who could physically intimidate and repulse any foul play started by someone else. Questions are raised about the brutal methods of the Springboks. This All Black team in Glasspool's opinion came across as 'squealers'. Verdict was that New Zealand could- and certainly should have had at least a share in the series. However Glasspool saw the sole selector method as having greater chance for serious error and the biggest single factor in the New Zealand failures stemmed from Coach Stewart's disregard for the crucial need of an established goal-kicker in the tests and believes ignoring Laurie Mains was a blunder. Stewart believed he had brilliantly inventive players who could go out and play the game just "as the music in their heads dictated". However by taking their "pattern" football away from them in the hope that their own initiative would spring to the force, one of the anticipated strengths of the 1976 All Blacks became, in fact, a hindrance.

At their best the All Blacks played compelling rugby, at their worst they scrummed badly, fell into the trap of too much lateral movement, too little driving in the forwards and tended to over-elaborate in midfield instead of moving the ball quickly to the wings to stretch the South African heavyweights.

Glasspool also poses several questions about Springbok rugby's state of health and what the future holds in the light of political developments.

\section{G17}

Gray, Maryvonne. "It's Okay for 90's Blokes to Have a Ball!" Truth, 12 November 1999, 4.

The All Blacks' World Cup loss in 1999 could be the trigger for redefining Kiwi masculinity and the role of New Zealand on the world stage, according to counselling experts. Rugby has become such a major part of who we are, with fans being encouraged to dress in black and "be" the team, people feel they have been betrayed.

\section{G18}

Gray, Wynne. "Memories Ready All Black Coaches for Test." New Zealand Herald, 14 November 2002, B8.

John Mitchell and Robbie Deans remember their experiences playing French club rugby of which violence was a constant feature. But the pair was confident that much of the rugby thuggery of their generation had been removed, indeed Deans went so far as to suggest it is "not an issue in international rugby now". 


\section{G19}

Gray, Wynne. "World Cup a Till-Ringer That Dominates Landscape." New Zealand Herald, 21 June 2003, D5

Gray questions whether the World Cup good for rugby? Is it helping New Zealand rugby? While the World Cup creates revenue building Gray argues it devalues the merit of preceding test matches. To achieve a better idea about a global order of merit there should be regular tests between top nations.

\section{G20}

Greatrex, Terry. "The Story of the Cold Shoulder." New Zealand Listener 110, no. 2371 (27 July 1985): p 25.

Takes a look at the testy relationship that exists between the two rugby codes: league and union and explains why league still attracts suspicion from rugby union which is an example of the clash between amateur ideals and professional commercialism.

\section{G21}

Gregory, Angela. "Combative Rugby Taking Double Toll." New Zealand Herald, 11 August 2003, A10.

An Auckland club player is angry at assault that left him in hospital for two weeks while the offending club has not apologised. He argues that many players, especially those brought over from the Pacific Islands, appeared to not understand or appreciate the rules of safe tackling. Tongan coach Jim Love said the perception that Pacific Island players tackled dangerously and high was incorrect. Samoan Coach John Boe said the players spent a lot of time on tackle technique. Looks at the cost of new injuries in year to mid-2001. 
G22

Guinness, Rupert. "Kiwi Hatred Threatens Cup." The Australian, 2 December 2002, 14.

Australian officials have warned that unprecedented violent crowd reaction and hatred directed at Australian teams playing in New Zealand 7's could mar next year's World Cup if left unchecked. The Australian team were pelted with plastic beer bottles in the opening ceremony and jeered during each of their games by a packed local crowd rated as "hostile".

H1

Haden, Andy. Boots'n All. Auckland: Rugby Press, 1983.

Haden takes a critical look from a player's perspective at the issue of amateurism in an increasingly commercial rugby world. He asks if rugby can sustain the outer dimension that professional sport offers and is the amateur concept too costly for the players to support. He highlights and backgrounds difficulties with the administrators. Issues that inflamed his antagonism with the New Zealand Rugby Union included the boot fiasco with Adidas. Haden recounts episodes of bad behaviour by rugby teams including hotel destroying and his experiences with the 1972-73 All Black team. He looks at the issue of increasing regularity of tours meant amateur sportsmen weren't going to be able to abandon work and home as readily as the past. He casts a critical look at the media critics and explains his dive from the lineout against Wales. He offers his opinion on the issue of playing South Africa where Haden believed South Africa should be treated in a sporting context like any other country, to be engaged for sports sake regardless of the country's origins or doctrines. Haden proposes one possible solution to the problem of sporting contact with South Africa could be to tour only to the coastal areas where he believes the races mix with less tension and where whites appear to accept black and coloured people as part of their society and where they appear more receptive to change. Haden bears a sense of injustice because of the attention rugby players have received from those who oppose contact with South Africa and gives his view on the protestors. He gives an insight into the conservatism of the New Zealand Rugby Council and views on the issue of professionalism and how it would affect rugby in New Zealand. 
H2

Haden, Andy. Lock, Stock'n Barrel. Auckland: Rugby Press, 1988.

A follow up from his first book Boots' $n$ All (H1). Haden states that the issues of New Zealand, problems and our sports seem to be closely linked to what is happening in the Beehive (New Zealand Parliament buildings) or in the realms of the business world. He argues that if sport is going to be affected by politics so consistently perhaps it is time politics started being affected by sportsmen. The 1970s and 1980s were a time of great transition in rugby. The impact of television coverage of matches had been felt and the players were experiencing far greater pressure from the extra media attention focused on on-field performances and off-field deportment. The issues raised by his first book remained still in the mid 1980s. He criticises administrators and former players for taking the attitude "we didn't get that in our day-why should they?" He argues that it is no longer possible to argue that the decisions made by either the NZRFU or the IRB are made in the best interests of the players. He retells having to face charges from the NZRFU resulting from the publication of Boots ' $n$ All and other commercial activity in which he was involved and backgrounds the establishment of Sporting Contacts Ltd which is centred around the philosophy of firstly, promoting the commercial availability of New Zealand sportsmen and secondly, assisting the codes they represented to organize themselves professionally enough to face the demands of modern day sport. He criticises the NZRFU for having no accountability. Haden backgrounds the events and legal jousting that led to the High Court upholding the application for an interim injunction restraining the NZRFU from proceeding with plans to send the All Blacks to South Africa in 1985 which he argues that the principles of freedom of movement in and out New Zealand were compromised. Haden describes the steps undertaken to organize the Cavaliers tour and the antagonism towards the New Zealand media and covers the events. of

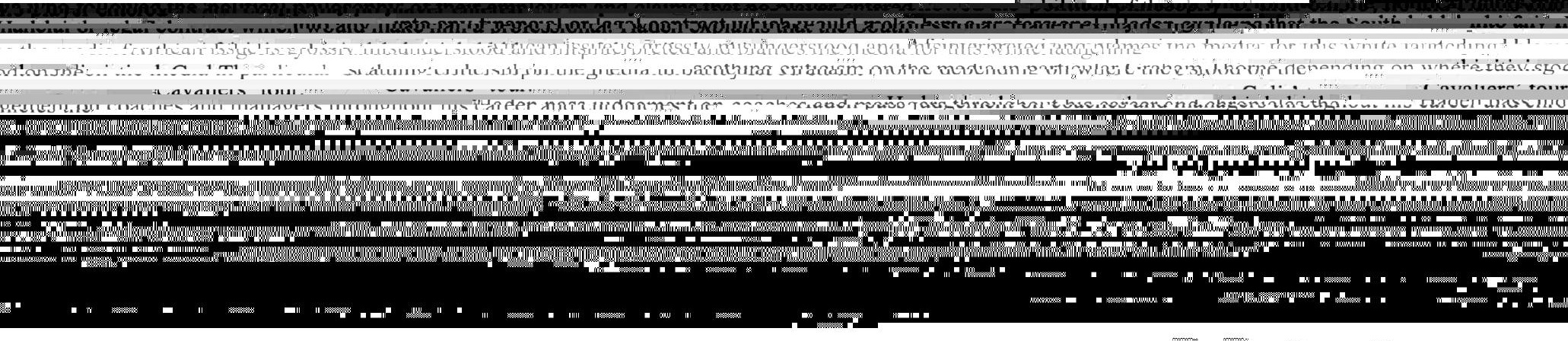

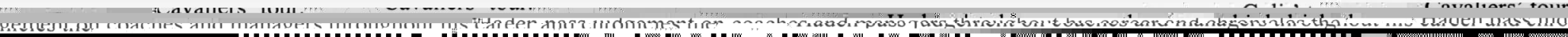

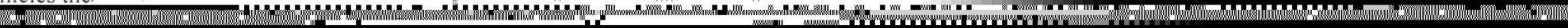

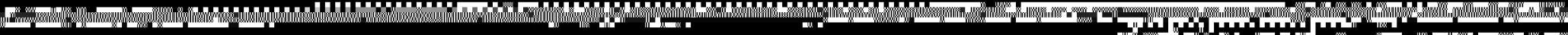

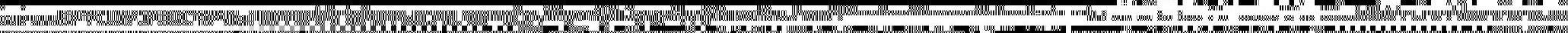

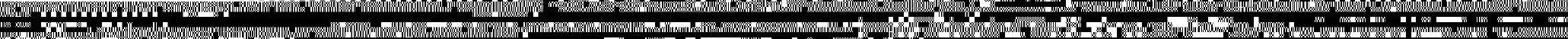


prepared to abdicate control. Haden contrasts the stars of the 70s and hypothesises how they would handle the late 80 s with the developments of the game on and off the field. In "Towards 2000" Haden looks into the future and hypothesises where the game is going.

H3

Haggie, Maryanne. "The Judicial Disciplinary Procedures of the New Zealand Rugby Football

Union." Victoria University of Wellington Law Review 29, no. 2 (1999): 317-46.

Overviews the interface between sport and the law and examines the model established by the NZRFU to deal with acts of violence on the rugby field.

\section{H4}

Halt All Racist Tours Movement. Stop the 1976 Tour. Wellington: P. Tyler for Halt All Racist Tours, 1975.

Booklet produced by HART which outlines their argument for opposition to sporting contact with South Africa.

H5

Hansen, David William John. "Just Part of the Game : An Investigation of Violence in the Game of Rugby." University of Waikato, 1990.

Thesis completes the Masters of Social Sciences Psychology, investigates respondent's attitudes toward foul play in rugby and how these attitudes vary according to the role a person plays in the game. The forwards role is more confrontational than the backs therefore more tolerant to foul play. 


\section{H6}

Harding, Grant \& David Williams. Toughest of Them All. Auckland: Penguin Books, 2000.

Comprehensive history of rugby between New Zealand and South Africa, written by a writer from each country exploring the rivalry which allows brutality to surpass the boundaries of fair play in the pursuit of victory.

H7

Harding, Grant. "Ease Eligibility Rules for 'Have Nots'." NZ Rugby World, September 2003, 16-17.

Harding proposes a review of the eligibility rules to help lesser nations be more competitive at the World Cup with particular emphasis on the Pacific Islands and players of Polynesian extraction that have played for the All Blacks.

H8

Harvey, John. The Mark of the Bull. Auckland: Hodder Moa Beckett, 1998.

Biography of Mark "Bull"Allen, shaven head prop who became a popular Taranaki icon. The beginnings of the professional era with the Super 12 franchise the Hurricanes is looked at in "Meet the family" where coping with public profile and professional life is examined. The creation of the image of the Hurricanes as a marketing theme decided to focus on entertaining style of rugby and selecting personalities. 'The good and the bad' examines the pros and cons of professional life and professional preparation is detailed in 'Making of an athlete'.

H9

Haynes, John. From All Blacks to All Golds. Christchurch: Ryan and Haynes, 1996.

Haynes tells the story of a group of All Blacks and top New Zealand provincial players who were responsible for starting professional football in Australia and New Zealand. They toured Australia and England and their eventual return to New Zealand saw the introduction to Rugby League they learnt to play 
in the north of England. Cast out by the Rugby Union at their time of leaving New Zealand in August, 1907 and being away for almost a year, they played 6 tests and other representative games against top professional opposition. Known as the New Zealand All Black Football Team, but dubbed "The All Golds" by an Australian newspaper who decried their endeavours to earn gate-money, they were eventually to turn that name into a glorious one. To Englishmen they were quite simply All Blacks following on in the tradition of the first All Blacks in 1905-06, some of whom were also in this professional team.

H10

Hayward, Jeff. "Rugby's Poor Cousins Mock Money Rule Plan." New Zealand Herald, 10 January 1990 , section $2,2$.

Hayward discusses International Rugby Board proposals to allow players to make some money from the game. Considers amateur and professional status in sport. British players mock the IRB's tentative steps from strict amateurism. They say that New Zealand, France and Australia are held as proof that leading players are cashing in on their rugby fame. Players mentioned are John Kirwan, Andy Dalton and Wayne Shelford. IRB changes will allow players to receive compensation for loss of earnings while training for and appearing in home international matches. Players will be able to take money for giving interviews and speeches, personal appearances, writing books and articles but falls short of allowing players to secure personal advertising and sponsorship deals.

\section{H11}

Hazledine, Tim. "Freeing Passions Can Deliver Top Results." New Zealand Herald, 15 November 1999, A13.

The All Blacks World cup performance reflects a country drained of spirit. French forward Abdel Benazzi said "All Blacks have great players. The Australians are a great team." While the All Blacks are a model of modern sports franchise perhaps overmanagement squeezes the spirit out of players. The author compares the All Blacks to New Zealand's underperforming economy. 


\section{H12}

Henry, Graham \& Bob Howitt. The X Factor. Auckland: Celebrity Books, 1999.

Autobiography of Graham Henry, coach of Auckland, the Blues and Wales. He makes a comparison of Super 10 and Super 12 competitions and describes the losing of players to rugby league. He gives a description into the violently explosive 1994 NPC final between Auckland and North Harbour. He provides an insight into a coach of an amateur team approaching the professional era. In "hitting the zone" he describes the mental application of a professional player. He highlights the problems of attitude of All Blacks in 1998 and provides his views on professionalism and attitude that comes with it and gives a prediction of the 1999 World Cup failure of the All Blacks. Planning during the amateur era is contrasted with the professional era. Criticism is directed towards the boorishness of Canterbury fans. Henry outlines the plight of professional clubs and backgrounds his decision to accept the offer to coach Wales and the reaction of the NZRFU that threatened to ban him from ever coaching the All Blacks as a reaction to the player/ coach drain, named the Henry Clause.

\section{H13}

Hope, Wayne. "Whaddarya?: The Political Economy of Professional Rugby." New Zealand Political Review 5, no. 3 (1996): 20-23.

Considers how the televising of sport has led to its commercialisation. Studies how this has led to the professionalisation of New Zealand Rugby Union with the exposure to their financial earning capabilities.

\section{H14}

Hope, Wayne. "Whose All Blacks?" Media, Culture \& Society 24, no. 2 (2002): 235-53.

Wayne Hope takes a closer look at the concerns on the stature of All Black rugby in New Zealand following the bitter disappointments of the 1999 World Cup and following failures in Tri Nations tournaments in 2000 and 2001. He examines the history of the rugby football in New Zealand, discussing the effect of professionalism on New Zealand rugby. Highlights the coincidence of the introduction of live television coverage with rugby's contested cultural centrality and looks at reasons of the tensions between global media-sport and territorial identification. 
H15

Hopkins, John. Life with the Lions. The Inside Story of the 1977 New Zealand Tour. Auckland: Hutchinson, 1977.

Hopkins reports on the major provincial games and the series of tests which led up to the stormy final match at Auckland. He describes the day to day pressures that confronted the team, includes profiles of Lions coach John Dawes and his rival Jack Gleeson, the All Blacks coach. Also includes interviews with Robert Muldoon the Prime Minister of New Zealand discussing contacts with South Africa. He explains what the Lions did on tour when they weren't playing rugby.

\section{H16}

Howitt, Bob. Grant Batty. Auckland: Rugby Press, 1977.

The biography of one of the charismatic stars of New Zealand rugby throughout the turberlent 1970s. Recalls his days as an exciting teenager introduced to the hard nosed, sometimes violent senior club rugby in Wellington. His first tour as an All Black was the controversial 1972-73 tour to the United Kingdom, Ireland and France which he describes it as "...the happiest tour I ever went on. Contrary to so much nonsense thats been written, we were a really happy team". Describes the difficulty communicating with the British press and the persona of the Keith Murdoch, "... he was branded even before he got to Britain. They published a cartoon before the tour which depicted him as some sort of wild animal in a cage".

Murdoch is described as a great player and team man "no worse than hundreds of other players who've toured". Other references are made to the "Mafia" tag given to Alex Wylie, Alan Sutherland and Tane Norton. Batty was the New Zealand star in the Barbarians game scoring two brilliant tries which is widely considered to be perhaps the most spectacular, most crowd-pleasing international match ever staged. One chapter is devoted to Ian Kirkpatrick who was the captain of the 1972-73 team and who, despite strong personal form was accused of weak leadership that allowed bad behaviour follow the team.

Includes tour descriptions of New Zealand to Australia 1974, New Zealand tour of Ireland 1974 and the injury that plagued him from 1976, through the tour of South Africa until his last test against the 1977 Lions. Batty recounts in first person the events leading up to that test and his famous try, describing vividly the atmosphere as an All Black prepares for a major international match. 
H17

Howitt, Bob. Super Sid. Auckland: Rugby Press, 1978.

Biography of North Auckland and New Zealand half back Sid Going. Follows Going's career from early days as a farmer, through his years as a Mormon missionary in Canada to his representative career with North Auckland and the All Blacks. Sid's brothers Ken and Brian and coach Ted Griffen have their story told too.

Howitt covers Going's selection in 1967 for the All Blacks while touring the UK and France in 1967. It details the rivalry for the half back position with Chris Laidlaw. Covers in great detail the All Black tour to South Africa in 1970 - Going being among the first non-whites to be allowed to tour the Republic. The training runs under Ivan Vodanovich are described as exhaustive. Also examines Ranfurly Shield glory and the Lions' tour in 1971. Sid is accused of being sullen and part of the 'mafia' during the controversial tour to the UK and France in 1972-73. The Keith Murdoch incident and its ramifications is explored as is Murdoch's relationship with journalist Terry McLean and the antagonism with the UK press. Other major events covered are the centenial tour to Ireland 1974, the tour to South Africa in 1976 including the anger of the All Blacks at South African referees and finally the Lions tour to New Zealand 1977. Also includes a Selection of a Sid Going World Team and New Zealand team.

\section{H18}

Howitt, Bob. Beegee : The Bryan Williams Story. Auckland: Rugby Press, 1981.

Voted New Zealand player of the century, Williams was amongst the first non white players to be allowed to tour apartheid South Africa in 1970. Backgrounds his life growing up in Polynesian dominated Ponsonby. Williams gives his perspective on the Sid Nomis- McCormick incident and returned home from South Africa in 1970 convinced he had achieved a modest personal goal- to put a chink in that country's armour regarding apartheid. He recounts the decline and fall of Keith Murdoch amongst other alcohol induced bouts of misbehaviour from the rest of the team during the controversial 1972-73 tour of Britain and France and described the British animosity towards the All Blacks which reached a peak particularly in Wales. The difficulties of the reality being an amateur player like getting time off from work relied on the generosity of employer. Williams laments the departure and reasons for Joe Karam defecting to league and debates the need for payments to international players and describes his hero treatment by South Africa's non whites. "On the comeback trail" he compares the change of attitudes of the 1972-73 and 1978 tour of Britain with the latter tourists making an effort not to be so insular. The controversy still was present with Williams recounting Andy Haden's dive against Wales in 1978 and the furore of JPR Williams' cheek 
being sprigged by John Ashworth in the violent clash with Bridgend and looks at the virtues of amateur rugby, prediction of the 1981 Springbok tour and criticism of the New Zealand rugby council.

\section{H19}

Howitt, Bob. Inga the Winger. Auckland: Rugby Press, 1993.

Biography of Vaáiga Tuigamala, Samoan born All Black who was part of the early wave of powerfully built Polynesian wingers. Nicknamed Inga, he engages the subject of racism and the pressure of playing top level rugby in the last years of the amateur era. He discusses his tempting offer from Wigan rugby league club to switch codes.

\section{H20}

Howitt, Bob. Roar of the Crowd : New Zealand Rugby's Greatest Players, Famous Games and Memorable Matches. Auckland: Penguin Books, 2000.

Howitt has sought to capture many of the diverse happenings which have gone together to make rugby the enchanting sport it is and how it entrances New Zealand society. This book includes pen portraits of the great players : Colin Meads, John Kirwan, Don Clarke, Maurice Brownlie, Grant Fox, Kevin Skinner and his pugalist reputation from the 1956 series against the Springboks, Jonah Lomu, Zinzan Brooke, Bruce Robertson, Ian Kirkpatrick, George Nepia, Kel Tremain, Bob Scott, Bryan Williams, Michael Jones, Bert Cooke, Waka Nathan, Jeff Wilson, Wilson Whineray, Sean Fitzpatrick, Sid Going and Brian Lochore. Howitt includes a selection of great games including Ranfurly shield challenges and test matches.

The key sections contain the Early Days -when rugby was an "excuse for anarchy and violence"; Bok Busters- New Zealand 's 1996 series win in South Africa, Birth of televised rugby where New Zealand officials were reluctant to allow live television, the 7's national side strike gold in Kuala Lumpur's Commonwealth games and the 1986 Cavaliers tour of South A frica.

Also includes a chronology of key moments in New Zealand rugby history. 
H21

Howitt, Bob. "Jock in the Chair." NZ Rugby World, October 2002, 20-28.

Profile of Jock Hobbs who was appointed by the NZRFU to convince the players to reject the WRC offer in 1995 and declare their allegiance to the NZRFU. Voted to the chairmanship of the NZRFU after the debacle of the sub hosting fiasco. Also profiles the new board members.

H22

Howitt, Bob. "O Rugby Bloke, Rugby Bloke, Wherefore Art Thou Rugby Bloke?" NZ Rugby World, April 2002, 40.

Howitt laments the dominance of lawyers and corporate businessmen in the NZRFU board and argues that if "real rugby blokes" were in control, New Zealand would not be in danger of losing the sub hosting rights.

\section{H23}

Howitt, Bob \& Dianne Haworth. Rugby Nomads. Auckland: Harper Collins, 2002.

Howitt and Haworth collect stories from New Zealanders who travel abroad to play and coach rugby. While the issue of playing and coaching overseas is becoming more commonplace in the professional era, included are also jet setters in the amateur era who expand the rugby horizon. Among these travellers are international players who have plied their trade in New Zealand. Laurie Mains reveals a sensational story of sabotage in the Super 12, Alex Wylie talks of wanting to quit before the 1991 World Cup, Josh Kronfeld tells how NZRFU apathy drove him overseas and Andy Leslie describes the shock of being dumped by his British club. 


\section{H24}

Howitt, Bob \& Robin McConnell. Laurie Mains. Auckland: Rugby Publishing, 1996.

Biography of Laurie Mains, All Black and Otago fullback of the 1970s who became coach of Otago during the 1980s and New Zealand during the last years of amateurism. Mains' tenure saw an accelerated drive towards greater commercialisation of the All Blacks. With the assistance of the then Lion Nathan executive Neil Roberts, during Mains' four year term as coach, Steinlager made a historic commercial breakthrough by getting their name on to the All Black jersey and shorts, with a subsequent increment in sponsorship. The establishment of the All Blacks club would arrange for up to 10 All Blacks at a time do sponsorship work for financial backers helping to fight off the threat from rugby league. He provides a defence for hardman prop Richard Loe who was involved in a controversial incident against Australia in the second test in 1992, breaking Paul Carozza's nose and then eye gouging Greg Cooper in the NPC final later that year for which he received a ban through the 1993 season. Mains describes the public backlash and pressure on himself and the All Black team following New Zealand's second test defeat at the hands of the Lions in 1993 and the frustration of losing top players to rugby league which had become more of a problem than any other time in New Zealand's rugby history. The controversy of the 1993 tour to England and Scotland is recounted where the All Blacks were labelled by the British Press as one of the dirtiest teams to tour. Incidents included the rucking which led to an injury to Philip de Glanville and Jamie Joseph stomping on the ankle of Kyran Bracken. Mains reveals the growing bewilderment at the New Zealand Rugby Council's administrative and political interfering towards the All Black selection panel. Mains discusses the meeting with Australian rugby league coaches Wayne Bennett and Bobby Fulton to exchange ideas, something unheard of previously and describes the furore over the Johan Le Roux biting Sean Fitzpatricks ear during the 1994 Springbok tour of New Zealand. "Confusing the enemy" explores the planning for the 1995 World Cup and recalls the allegation that Sean Fitzpatrick racially abusing English prop Victor Ubogu. "The show goes on" looks at the development of the WRC and News Limited tug of war for the services of rugby players for professional rugby. WRC being initially favoured as suspicions lingered that Rupert Murdoch's empire was more concerned with Super League. Details the rescue attempts by the NZRFU led by Jock Hobbs to secure the players for the All Blacks. 
H25

Hughes, Charlotte. "A Common Code?: Hegemonic Masculinity and the 1981 Springbok Tour of New Zealand." University of Auckland, 2001.

A thesis submitted in partial fulfilment of the requirements for the degree of Master of Arts in History, University of Auckland. This thesis looks at the 1981 Springbok tour from a perspective of hegemonic masculinity and its challengers. Despite a small number of critical voices, the values associated with hegemonic masculinity underwrote a variety of debates and practices during the Springbok tour. Hughes argues that these values represented a 'common code'. Diverse sections of the community, including both anti-tour and pro-tour advocates, played along with the set of dominant assumptions about gender.

Before 1981 the All Blacks were the representatives of hegemonic masculinity providing a template against which to compare the gendered expectations of those concerned with the tour. Chapter one reveals similarities between police, anti-tour protesters and the All Blacks that relate to the actions of the body. A 'masculine' code of physical conduct saw all three aligned with the military or acts of war. In each case, the body was governed by concerns about domination and discipline, as well as the notion that men of an appropriate age were more capable participants than women, youths or the elderly. Chapter two showcases patterns of similarity that relate to the 'nation'. The All Blacks had long been applauded as men who put themselves 'on the line' for their country. An associated pattern saw rugby and its male participants used to characterise the 'nation'. In 1981, tour commentators endorsed both of these ideals. Men were often said to act for the nation in ways that resembled the efforts of the All Blacks. Moreover, even those who were not particularly fond of rugby believed that the game moulded the national 'character'. Chapter three discusses three further similarities. The All Blacks, the police and, to a lesser extent demonstrators relied upon a gendered division of labour; men took part in the 'real action' while women filled domestic and subordinate roles including that of caring for children. The All Blacks and tour commentators also revealed similar assumptions about sexualities. Heterosexual men were pre-eminent. They controlled female sexuality and stood as the benchmark against which 'deviant' sexualities were measured. Finally similar ideals came to light in relation to non-white masculinities. In rugby circles, Maori men were hailed as the equals of their Pakeha counterparts. Ironically, they were also aligned with racial stereotypes about the inferior native. This same contradiction underwrote references to non-white men involved with the Springbok tour. In 1981, the values associated with hegemonic masculinity were diffused amongst a wide range of people. 
J1

Jackson, Steven J. "Beauty and the Beast : A Critical Look at Sports Violence." Journal of Physical Education New Zealand 26, no. 4 (1993): 9-13.

Outlines some of the problems that encompass the concepts of violence and aggression. Examines some of the contradictions that emerged in the 1992 case of Richard Loe, treated sympathetically by the New Zealand public when he smashed Wallaby winger Paul Carroza's nose and was then banned for eye gouging his All Black team-mate Greg Cooper in the NPC final against Otago. Illustrates the sometimes schizophrenic nature of the media as it condones and condemns violence and makes reference to the relationship between sport and domestic violence.

\section{J2}

Jackson, Willie. "Racism Behind Fury over Anthem Sung in Maori." New Zealand Herald, 15 Oct 1999, A15.

Comments on the negative reaction to the decision by singer Hinewehi Mohi to sing only the Maori version of the national anthem before the Rugby World Cup match between England and the All Blacks October 1999. Jackson believes the reaction is typical of a racist attitude that holds this country back.

\section{J3}

James, Colin. "NZ Digests the Reality of a Million-Dollar Pastime." Business Review Weekly 17, no. 35 (1995): 64-65.

Looks at rugby football as the national sport in New Zealand and amateurism as an inspirational value while focusing on the impact of the professionalization of the sport in New Zealand. New Zealand's victories in the field of rugby football are highlighted. The management of the New Zealand Rugby Football Union (NZRFU) contemplates the future in the advent of the shift to rugby football professionalization. 
James, Colin \& Jane Sayers. "For Cash and Country." Far Eastern Economic Review 158, no. 39

(1995): 78-80.

Rupert Murdoch offered NZ\$828 million for television rights to a new, professional world rugby series. The 3 main rugby-playing nations of the southern hemisphere - New Zealand, Australia, and South Africa - found his offer irresistible. Faced with this revolt from the game's dominant nations, the International Rugby Board, the sport's controlling body, on August 27 abandoned the amateur cause and removed all barriers to payment of players at all levels, hence making Rugby union fully professional. The interment of the amateur myth cements a profound change in New Zealand society where the honour of playing for the All Blacks is now matched by the capability of making a fortune.

J5

Johnson, Tony. "Dropping the Ball." Metro, no. 252 (June 1995): 91-92.

Reports the IRB press conference in London, England and discusses the aims of rugby towards state professionalism and provides discussion on the time for player to accept payment in playing including implication of money and greed by the advocates of amateurism.

J6

Johnson, Tony. "Hart Failure." Metro, no. 222 (December 1999): 45-46.

Discusses John Hart's dismissal as the coach of All Blacks and the role of the All Blacks' failure in the 1999 World Cup in the dismissal. Contains criticisms on Hart's coaching and management style. The ability of Taine Randell as the team captain is argued over whilst also looking at the bitter reaction of the New Zealand public to defeat.

\section{J7}

Johnson, Tony. "Kings of the Blues." Metro (NZ), no. 217 (July 1999): 36-37.

Looks at the performance of the Auckland Blues in the 1999 Super 12 rugby football tournament and explores the relationship between coach Jed Rowlands and the players which eventually led to a player revolt. The laidback style of coaching of Rowlands is discussed. 
J8

Johnson, Tony. "So Who's Watering the Grass Roots?" NZ Rugby World, October 2002, 24-25.

Johnson peruses the new board voted in after the World Cup hosting debacle of 2002 and asks whether this new board will be better, arguing that Tim Greeson, who was voted out, had an enormous amount of experience. Johnson also looks at a closer definition of "grass-roots" rugby.

J9

Johnson, Tony. "The Strain, the Drain, the Pain - That Was the Season That Was." NZ Rugby World, November 2002, 16.

Johnson looks at the fatigue factor and argues that while players don't need to be mollycoddled they do need to be handled with some thought to their long term future.

J10

Johnson, Tony. "Beware the 'Pro-Am' Minefield." NZ Rugby World, August 2003, 22.

Johnson is wary of any moves to separate professionals and amateurs in New Zealand's domestic competitions and argues that the coaching of school players needs to be addressed where coaches fill the first XV with the biggest strongest boys and beat the opposition by smashing them. The downside is that when every one else is the same size their skills let them down.

J11

Johnstone, Duncan. "The Day an All Black Cried." Sunday Star Times, 17 August 1997, A1.

All Black half back and former captain David Kirk talks about the anger directed at him by some of the Cavaliers in 1986 when he made himself unavailable for the tour to South Africa staying back to captain the "Baby Blacks"and compares the rebel tour to the attempt of the World Rugby Corporation to woo the All Blacks in 1995. 
J12

Johnstone, Duncan. "Haden Lifts Lid on Big Cash Payments to Cavalier Rugby Rebels." Sunday Star Times, 15 August 1999, A1.

Andy Haden, the man who organised the Cavaliers tour of South Africa in 1986, has come clean on player payments, saying the rugby rebels received $\$ 50,000$ each for the trip. "The South Africans had got us a sponsor and we got far more match tickets (to on-sell for the team fund) than ever before". Louis Luyt, president of the Transvaal union that organised the tour refused to acknowledge player payments.

$\mathbf{J 1 3}$

Johnstone, Duncan. "Needle': I Rejected Big Bucks to Coach Cavaliers." Sunday Star Times, 17 November 2002, B10.

Fred "the Needle" Allen confides he was offered \$150,000 to coach the rebel Cavaliers, but turned it down as he did not believe in the concept of the rebel tour and thought it would harm rugby. This was the second time he had rejected big cash, the first time being after the "Kiwis" tour in 1945-46 when rugby league wanted his services.

K1

Kay, Richard. "The Influence of Sport on Social Values. An Examination of Persisting and Changing Themes in the Depiction of New Zealand Rugby Union Football c. 1940's-1990's with Particular Reference to the Publications of TP McLean." University of Waikato, 1992.

With his thesis to complete an M.A. in History, Kay explores the relationship of history, sport and society by investigating the perception and meanings that have been attached to rugby by the sports journalist and author TP McLean. By working within the framework of McLean's books Kay identifies and analyses specific themes in New Zealand rugby history.

The study is organised into five main areas of discussion. The introduction identifies sport as a significant part of social and cultural life. The first chapter examines McLean's biographical background and his role and status as a journalist. The second chapter examines his books with particular emphasis on persisting and changing themes. The following two chapters examine the aspects which recur and the impact that sport, not just rugby has had on people's lives. Discipline, violence and the seriousness of rugby undertaken by New Zealand society are key aspects that are examined. 
K2

Kayes, Jim. "Rugby's Boardroom Brawl." Dominion, 23 Feb 2002, weekend magazine, 1, 5.

There was an angry reaction from Australia and South Africa to New Zealand blocking an expansion of the Super 12 rugby tournament in 2001.

K3

Kervin, Alison. "The Death of Amateurism." Rugby World (1995): 26-27.

Focuses on the issue of professionalism in rugby football in the southern hemisphere. Rugby is seen as a pawn in the battle between media magnates Kerry Packer and Rupert Murdoch which spawned the Super Twelve series. Also details the attempted coup by Packer's World Rugby Corporation to control professional rugby and the signing of the All Blacks to a professional game.

K4

Kervin, Alison. "Money Can't Buy Everything." Rugby World, no. December 1996 (1996): 7.

An opinion commentary on the professionalism of rugby football players in New Zealand. It examines the effects of multi-million dollar contracts on players, and other fundamental problems such as the widening gulf between the rich and poor in rugby. Kervin gives an overview of player development in the southern hemisphere and the role of program development on player acquisition.

K5

Kirk, David. Black \& Blue. Auckland: Hodder Moa Beckett, 1997.

Autobiography of David Kirk, the Rhodes Scholar and World Cup winning All Black captain in 1987. Includes the fall-out between himself and some of the Cavaliers over Kirk's non-availability for the rebel tour. He comments on his career spanning the commercialisation of rugby in New Zealand while he maintained amateur links. His career then focused on coaching the Wellington NPC team. His falling out with some Wellington players who insinuate that Kirk was racist is covered. 
Kirk, David. "Look Beyond Game to Plumb What Causes Violence in Society." Sunday Star Times, 22 August 1999, B3.

David Kirk responds to criticism that rugby is directly linked with the subject of violence in New Zealand. He responds by stating that New Zealand rugby has never been cleaner in the climate of professionalism and regime under John Hart.

K7

Knight, Lindsay. Kirky. Auckland: Rugby Press, 1979.

Biography of Ian Kirkpatrick, All Black from 1967-1977 and who was captain during the controversial 1972-73 tour to Britain, Ireland and France. Kirkpatrick gives his views on contact with apartheid South Africa and remains convinced that both he and New Zealand did the right thing by going to South Africa and believes rugby has been given little credit for some of its positive contributions in breaking down some of the uglier aspects of South Africa's apartheid system. He maintains sport and politics should be kept separate and a belief that South Africa's internal problems are for it to solve itself, not outsiders. Kirkpatrick makes a comparison with the 1971 Lions and the All Blacks of 1972-73 with the belief that the Lions' bad behaviour was largely ignored by the press and that courtesy should have extended to his team. Knight looks in depth at the 1972-73 tour to Britain and France with Kirkpatrick emphatic that hard man and perceived trouble maker Keith Murdoch did not deserve the treatment he received, nor was he the villain so many people have painted but rather he was a victim of much of the unwarranted hysteria that surrounded the tour largely because of the extreme attitudes adopted by some of the press, especially the Welsh. He opines what rugby means to New Zealand in contrast with Wales. Kirkpatrick gives his version on the violence of that tour. Kirkpatrick gives his reaction to the cancelled 1973 Springbok tour to New Zealand. His thoughts on the 1976 tour to South Africa is examined where Kirkpatrick remains convinced New Zealand should maintain its contacts but says that at the time and now he found the attitude of many of his countrymen understandable and admits there were quite a few in the team who thought the same. He also describes being caught up in a race riot in South Africa. He devotes a whole chapter on his thoughts on professionalism where he also criticises the IRB and reveals the offer to switch to league. 
Knight, Lindsay. The Geriatrics. Auckland: Moa, 1986.

Biography of the three front-rowers who set the platform for New Zealand to dominate international rugby from the late 1970s to the mid 1980s, Gary Knight, John Ashworth and Andy Dalton. Each has been involved in controversy. Ashworth achieved notoriety for rucking JPR Williams' cheek against Bridgend and profiles the bitterness of Wales and New Zealand rivalry. The issue of too many tours for the amateur era is covered with the three players having to forgo some tours as it became impossible financially for them to leave their farms and jobs. While playing Argentina Ashworth got involved in an assault on Hugo Porta, the Pumas captain. Knight examines the 1981 Springbok tour of New Zealand and the effect on the players families by the threat of protestors. This only made them more determined to continue playing their game for what they saw as an essential reaffirmation of their basic democratic rights and freedoms. Dalton having toured Romania and the oppression there strengthened even further his conviction that New Zealand should preserve its links with South Africa. Also detailed are the events that led to the cancellation of the 1985 tour to South Africa by legal proceedings while their frustrations at being denied their chance to tour leads to the construction of the Cavaliers plans. Dalton offers the opinion that the IRB's refusal to keep South Africa in the international fold would invite professional rugby. The claims that the Cavaliers were paid huge sums thus contravening their amateur status were not proven. Dalton played little part on the field after he was king hit by Burger Geldenhuys resulting in a broken jaw. Other violent incidents included the all in brawl against Natal. The front-rowers remark upon the changes that rugby has experienced through the 1970s and 1980s. These included an upsurge in electronic media, the intrusion of modern marketing methods and increased opportunities for touring and travel. The emergence of David Lord and the professional tournaments and the dissatisfaction with the IRB were other features that have characterised the 1980s. There is profile of Dalton working within the games infrastructure and he states that Rugby has got to make up its mind whether it is going to become semi professional or stay amateur. While Dalton hopes that amateurism ethics and philosophy remains, Ashworth points out that these principles can be a weakness as rugby officialdom has been slow to recognise the vast changes in the game. Other points for future upgrading are seen as 1) the role of club rugby. 2) A much more commonsense attitude to players endorsing advertising products. 3) the place of women in rugby. 4) addressing problems posed by the labyrinth of laws and 5) ensuring the World Cup remains a regular on the international calendar. 
K9

Knight, Lindsay. They Led the All Blacks. Auckland, NZ: Rugby Press Ltd, 1991.

Knight looks at the men who had the honour and privilege of leading the All Blacks into battle. The book is an attempt to define some of the mystique which has gone with being an All Black captain. While most of the attention is on the post war captains, Knight includes a chapter on the early leaders. The other chapters are dedicated to the following : Fred Allen, Bob Stuart, Wilson Whineray, Brian Lochore, Ian Kirkpatrick, Andy Leslie, Graham Mourie, Andy Dalton, David Kirk, Wayne Shelford. In chapter 12 Knight interviews two celebrated captains of previous Lions teams to get their perspective of the mountainous task involved in captaining a side against the All Blacks.

\section{K10}

Knight, Lindsay. "Springbok Prop Breaks Silence on Kicking All Black." The Dominion, 21 August 1999, 50.

1956 Springbok prop Jaap Bekker has admitted to Keith Quinn that in the fourth test at Eden Park of the epic series of that year he deliberately kicked All Black lock Tiny White in the back forcing White to leave the field, though he was not the intended target which was Kevin Skinner.

\section{K11}

Knight, Lindsay. "'Tourmoil' in '81." NZ Rugby World, June 2001, 24-35.

Knight recalls the trauma, turmoil and controversy of the Springbok tour of New Zealand in 1981. Included are the thoughts of John Minto, leader of HART and Andy Haden who is still bullish about participation. Stu Wilson, Allan Hewson, Gary Whetton, Chris Laidlaw, and Malcolm Dick offer their recollections of the tour. 
K12

Knight, Lindsay. "Forget the Anzac Spirit." NZ Rugby World, April 2002, 38-41.

Knight looks at the increasingly likelihood that New Zealand will lose the sub hosting rights to the Rugby World Cup and comes to the conclusion that the Australians saw a chance to exploit a New Zealand weakness and take the entire tournament for themselves. He argues that New Zealand cannot avoid taking a more independent stance and think and act more in their own self interest. He casts his eye over the deep resentment of the effects of professionalism and looks at the challenge of funding while providing a less cluttered and stressful international programme.

\section{K13}

Knight, Lindsay. "Salary Cap : The Pros and Cons." NZ Rugby World, November 2002, 70-74.

Knight looks at the question of the rich provincial unions getting richer and stronger while the poor unions get poorer and weaker. With the NPC first division dominated by major unions who hold the Super 12 franchises there have been demands for the introduction of a salary cap. There appear to be two main presumptions about the impact of professionalism, firstly making it impossible for unions other than the big 5 who hold super 12 franchises to win major prizes and secondly that it is impossible to become an All Black, not just from second and third divisions but also the non Super 12 first division unions. Knight looks at the issue of player movements from smaller unions to bigger unions. The pros and cons of implementing a salary cap are investigated. Ian Jones provides the most striking example of the fact that to remain an All Black in the modern era players have to switch unions.

\section{K14}

Knight, Lindsay. "So, Who Are the Dicks Now?" NZ Rugby World, May 2002, 26.

Knight asks the question that in 1987 the World Cup went pretty well for hosts New Zealand why didn't the NZRFU bother to seek out anyone of the organisers of that inaugural event. Knight talks to Dick Littlejohn who concludes that it appears that some of the high standards and precedents which were set up in 1987 were not followed. 
K15

Knight, Lindsay. "Union Jacknife." NZ Rugby World, May 2002, 22-23.

Knight reports that even before the massive fallout from the World Cup sub hosting debacle, sagacious rugby administrators throughout the country were calling for less corporate-style governance out of Wellington and a return to the more homespun approach. Now the calls are getting louder and longer. John Dowling argues that the NZRFU could have done with people like Jock Hobbs and the current administration are not equal to one Cez Blazey former chairman of the Rugby Union. Dowling who chaired the NZRFU sub committee set up to implement the Boston Report doubts that the reports recommendations and blames the appointment of David Moffett as chief executive over George Verry in 1996. The present inexperienced administration had erred in not consulting those with a wealth of rugby knowledge. Other administrators criticise the marketing interests and corporate culture taken over at the expense of the rugby ethos.

\section{K16}

Knight, Lindsay. The Clubs. Auckland: Penguin Books, 2003.

Knight recalls the days when the likes of Poneke and Petone or Southern and University would frequently draw crowds of 10,000 or more and All Blacks regularly lined up to play for their clubs. $\mathrm{He}$ details the achievements of the major city and country clubs, as well as the Marist, Varsity and Old Boys networks, looks at the famous winning sequences and salutes the players who have given outstanding service to their clubs.

The introduction outlines the problems that are affecting club rugby in the days of professionalism. It acknowledges that problems, particularly for the city clubs had started many years before the 1990s. Changing socio-economic and demographics of New Zealand society have also contributed to obstacles that the clubs battle to overcome. 


\section{K17}

Kronfeld, Josh \& Brian Turner. On the Loose. Dunedin: Longacre press, 1999.

Autobiography of Josh Kronfeld who played for Otago and New Zealand, who is described as a free spirit in a sometimes conservative and stifling world of rugby. He recalls events such as being king-hit by Jason Chandler in the NPC final against Auckland in 1993. He gives us an insight into the style of Otago which anchored the style of the 1995 All Blacks. In 'Battle of the Boots' he describes the 'boot fiasco' concerning Nike, Mizuno, and the NZRFU. He provides good background on the motivation to smash England in the 1995 World Cup and the British media antagonism of the All Blacks. Kronfeld recalls the battle for control of rugby professionalism in 1995 with the establishment supported by Rupert Murdoch and the rebels backed by Kerry Packer and how he and Jeff Wilson decided to stick with the NZRFU which provoked the anger from some All Black team mates. When they toured France in 1995 Kronfeld explains his attitude towards French nuclear testing. John Hart's time as coach is covered in detail including Kronfeld's frustration with the mind games the coach used and the number of meetings he used. Kronfeld reveals the pressure and pitfalls of the media relationship with players and details the experience of playing as a professional during the early years of Super 12 and Tri-Nations.

\section{L1}

Labuschagne, Fred. Eye Witness in Sport. Wellington: A.H. \& A.W. Reed, 1970.

The first two chapters are dedicated to New Zealanders and their rugby sides, as the author found them such a 'fascinating study in "one-eyedness" and contrasting hospitality. Labuschagne gives an outsiders perspective of New Zealand society and rugby and how one affects the other. Colin Meads is the subject for the 2nd chapter "The Great Pinetree". The Lions test in Dunedin 1959 gets special attention, detailing the awkwardness the home crowd felt with the Lions playing all the attractive rugby but being beaten by New Zealand's goal-kicker Don Clarke. 
In chapter 1 Labuschagne recalls the meeting with the South African Minister of Sport Dr Koornhof that dispelled any hopes that the Nationalist government would bend the inflexible laws on mixed sport. "Never at any stage had consideration been given to allow the South African Rugby board selectors to arrange a mixed trial, or to consider, without mixed trials, any of the stars of the SARU or federation teams for the Springbok side". It was made clear that mixed rugby at club, provincial and international level was impossible within the context of the governments present sports policy. This policy convinced Labuschagne that any future contact between New Zealand and South Africa was doomed. Real shock for South Africans was the reaction in New Zealand. The promised and therefore expected roar of disapproval and disappointment was nothing more than a pathetic whimper. Labuschagne criticises the motives of the anti-tour New Zealanders to the proposed tour of 1973 and also examines the motives of the South African rugby fraternity and how sincere were they to the concept of mixed rugby.

Past series are reviewed in particular the 1956 series in New Zealand highlighting the aggression throughout that series, Kevin Skinner as the enforcer in the third test, and Danie Craven imploring for a return of the running game which was put aside in favour of the forward game that New Zealand was playing so well ironically taught by the Springboks in 1949.

L3

Laidlaw, Chris. Mud in Your Eye : A Worm's Eye View of the Changing World of Rugby. Wellington: Reed, 1973.

Chris Laidlaw, former All Black half-back during the 1960s and early 1970s comments on life within the All Blacks, the influence of rugby in New Zealand and the state of rugby in general. He attempts to identify the causes of current dissatisfaction within the rugby community and to "analyse a system that that can bring itself into widespread disrepute over such aspects as its inability to face the South African issue squarely" and appraise the character of rugby in the 1970s in Britain, France, New Zealand and South Africa from within. Also takes a close look at the rugby fans.

Laidlaw looks at the uniformity of rugby and how it is played and administered by the conservative elements of society. His criticism of the IRB is that it shows little interest in the development of the game and makes every effort to preserve the staunchly Anglo-Saxon character. The IRB's traditionalism does not put the organisation in a position to defend amateurism and ward off increasingly professional and commercial activities. Laidlaw casts his eye over issues such as the influence of beer on rugby, live telecasting and the reaction to defeat. Warning is given of the continuous season that will 
impinge on the amateur ideal and the effect of rugby on the New Zealand youth and the amateur volunteers. Rugby is examined as social status in the schools, the image of the All Blacks must conform to and problems facing youth rugby. Conformity in New Zealand society is discussed while commentating that the homogenous make up of the All Blacks helped keep them strong while discussing hierarchical structure of New Zealand. Life on an international tour is exposed and relationship with the press with specific reference to the 1972-73 tour and comments on commercialism becoming more prevalent in rugby and the rivalry with rugby league.

The former half-back looks closely at the style of play, with the contrast of styles before 1965 to current style and gives reasons why New Zealand played a forward style of game. Election and selection processes are analysed and criticises the administration of the game. Laidlaw offers his opinion on the vexed South African question and warns of bad behaviour of rugby fans getting out of control.

Aspects of violent play are examined with particular reference to Colin Meads being sent off against Scotland. He provides an insight of the media relationship with rugby and comments on rugby literature. The emergence of British rugby is commented upon as is the Welsh perspective on New Zelanders and vice versa. Laidlaw comments upon the growing professionalism and apartheid issue in South Africa while going in depth into his decision to tour in 1970 and how he has changed his position towards South Africa becoming a critic of the Republic. The lack of strong leadership and presence of political expediency has led to the controversy of contact with South Africa.

\section{L4}

\section{Laidlaw, Chris. "Big-Business Rugby Puts Egalitarianism in Danger." New Zealand Herald, 19} October 1998, A13.

Laidlaw warns that the move to professionalism in rugby has changed the culture of the game in New Zealand and threatened its egalitarian tradition. The almost total commercialisation of rugby and other sports means players are no longer playing for their fans, but for the media and big money sponsors.

The transformation of rugby in many ways mirrors the transformation of New Zealand society. Where before there was a fierce sense of egalitarianism, now there are two classes of participants: those with resources and those without. Professionalism has ushered a new elitism in rugby. Renumeration has meant the professional elite have forfeited their independence, becoming vassals of a new corporate ethic. There is a risk that the All Blacks will lose touch with ordinary people simply by virtue of money. 
L5

Laidlaw, Chris. "For Love and Money." New Zealand Books 9, no. 5 (1999): 8-9.

Laidlaw discusses the importance of sport including rugby in the national identity and psyche of New Zealanders and how the perception of sport in the public eye has been influenced by its commercialisation and also mentions the increasing number of women, Maori and Pacific Islanders sports heroes.

\section{L6}

Laidlaw, Chris. "Rugby, Beer Culture Creates Dilemma." New Zealand Herald, 13 February 1999, C7.

Some players have never escaped the clutches of alcoholism therefore it is important that the NZRFU follows through with professional support. Laidlaw asks why Norm Hewitt's' problem wasn't discovered or confronted earlier by rugby heirarchy. Rugby has difficulty dealing with problems of alcohol as it is such an entrenched part of New Zealand culture.

L7

Laidlaw, Chris. "Binding Ties Finally Broke." The Press, 14 July 2001, weekend section, 9

Laidlaw highlights the absurdity of the statement that politics and sport should not mix. Rugby was the tie that bound the Pakeha and Boer settler societies together in a perpetual embrace through the medium of a single sport which had come to assume a primal means by which each society expressed itself: the expression of legitimate violence and masculinity through rugby. 
L8

Lally, Renee H. (Renee Helen). "Annual Clashes of Ancient Rivals : A Story of Schoolboy Rugby Rivalries." University of Canterbury, 2000.

A thesis submitted in partial fulfilment of the requirements for the degree of Masters of Arts in Sociology in the University of Canterbury. The thesis explores schoolboy rugby rivalries with particular attention given to Christ's College and Christchurch Boys High School and between Timaru Boys High School and Waitaki Boys High School. These rivalries involve their own traditions and rituals that are part of the school identity. The thesis places schoolboy rugby in the context of school history and the development of rugby in New Zealand. With the rivalries imbedded in Victorian values of masculine physicality combined with the educational values helped ensure the game would thrive. It explores the way rugby reputation not only creates identity for the schools but also for those who play the game.

L9

Lampp, Peter. "Pacific Islanders Born to Play Rugby." Evening Standard, 25 September 1997, 7.

An English perspective that argues that Pacific Islanders have made New Zealand an even stronger world rugby power, adding their explosive grunt to the flair of the Maori player and complementing the discipline and structure of those of European descent.

L10

Latimer, Billy. "Masculinity, Place and Sport: Rugby Union and the articulation of the 'new man' in Aotearoa/ New Zealand" University of Auckland, 1999.

Thesis submitted to the University of Auckland in partial fulfilment of the requirements for the degree of Master of Arts in Geography. This thesis examines the cultural construction of historically and geographically specific masculinities. Although continuously negotiated and contested, dominant versions of what it means to be a man are natural through a mythologizing processes.

In New Zealand rugby union has historically operated as an important arena for the construction of Pakeha hegemonic masculinity. This thesis contends that, just as rugby characterised the famed 'kiwi bloke's' rural-associated stoicism, the sport now embraces a contemporary urban sensibility. 
L11

Laws, Michael. Gladiator: The Norm Hewitt Story. Wellington: Darius Publications, 2001.

Biography of former All Black hooker Norm Hewitt, one of rugby's genuinely hard men, who experiences the highs and lows and struggling redemption. This provides an insight into New Zealand's national game and perspective on the coaches, contemporary players and administrators, as well as the money being a professional, politics within the sport and groupies. Hewitt gives his views on national coaches Laurie Mains and John Hart. Looks at the influence of alcohol and machismo inside the rugby scene and how it affected him personally and the adulation and pressure from being an All Black in the amateur and professional eras. Public expectation and reaction are explored as well as the psyche and reaction within the All Blacks.

\section{L12}

Laws, Michael. "Rich Man's Game." NZ Rugby World, February- March 2002, 30-31.

Laws looks at the increasingly unease with the social direction of our national game with uneven playing field professionalism has bought and the white flight of players, however the spectators tend to be white because middle class Pakeha can afford the season tickets.

L13

Laws, Michael. "The World Cup : It Gets Worse." NZ Rugby World, April 2002, 46-47.

Laws laments that professionalism has changed the nature of international rugby relationships at board level and foresees unfortunate repercussions that will endure long after the 2003 World Cup has been staged.

\section{L14}

Laws, Michael. "Why the World Cup Will Fail: And What to Do About It." NZ Rugby World, May 2002, 28-29.

Laws argues that New Zealand's incompetence in losing the rights to sub-host the World Cup could be disastrous for Australia and the World Cup as he believes rugby to be a minority sport in Australia and will struggle to attract crowds, the tickets will be too expensive and the presence of too many weak teams. He proposes a reworked World Cup separated into divisions. 
L15

Laws, Michael. "Show Me the Money." NZ Rugby World, June 2002, 20-21.

The South Africa exodus of players is compared with the New Zealand situation where professional rugby is seen by many as a passport to better things, younger players realise they must maximise they earning potential which draws criticism of greed. It was inevitable that professionalism brings costs and argues New Zealand is not wealthy enough to keep players.

\section{L16}

Laws, Michael. "Maori Rugby : Racist Rugby." NZ Rugby World, July 2002, 18-19.

Maori rugby want test status but opposition to this concept claim that it gives unfair advantage to players of indigenous blood while looking at the history of Maori rugby. Laws makes the suggestion that the Maori be missionaries for the international game and send them to lesser nations to lift rugby profile through their cultural and entertainment dimension.

\section{L17}

Laws, Michael. "The Tri-Nations Triumph : Feel Better Now?" NZ Rugby World, September 2002, 18-19.

While the Tri-Nations triumph feels satisfying, the tournament has helped erode the glamour and the players lose their lustre because New Zealand play the same teams far too often. Laws proposes a return of the old fashioned tours and wants the tri-nations to occur every second year.

\section{L18}

Laws, Michael. "Don't Pop the Champers Yet." NZ Rugby World, October 2002 2002, 18-19.

Laws criticises the media as being sycophantic and unprofessional over the World Cup sub hosting debacle by blaming the IRB, John O'Neill and Vernon Pugh instead of the incompetent NZRFU. Now that Hobbs and a new board have been elected he criticises the media for their outpouring of adulation 
and uncritical capacity and Laws warns that it may be too soon and real problems continue to beset rugby which he identifies as being money, the increasing racial divide where officials and coaches are white while the players are Polynesian, the game is boring, player retention, and provincial rugby where attendances are down and most of the players are not local.

L19

Laws, Michael. "Yet Again, Rugby Is the Fall Guy." NZ Rugby World, no. 60 (April 2003): 24-25.

Leading politicians and sportswriters continue to undervalue the achievements of rugby in New Zealand. Chief examples are the Halberg awards which chose to ignore the success of the Canterbury Crusaders winning the Super 12 going through undefeated and the All Blacks proving victorious in the Tri-nations. While rugby receives no funding from SPARC the All Blacks are more important to the New Zealand national and international identity than the America's Cup Team New Zealand or the basketball Tall Blacks.

L20

Laws, Michael. "Greedy Boys in Black." NZ Rugby World, August 2003, 24-25.

Laws criticises the current crop of players for being too greedy arguing over their World Cup bonus and examines the financial demands of the Players Association.

L21

Laws, Michael. "NPC: Is It Really Working?" NZ Rugby World, September 2003, 26-27.

Laws laments the sad state of lower division rugby and the fact that many teams now extensively utilise the loan system and employ the rejects of other teams and the lack of pakeha youth playing the game. Laws argues for more professionalism with the introduction of a variant of the American NBA draft system to even up the NPC. 
L22

Leigh, Jack. "The Power and the Glory and the Deep Dark Hole." New Zealand Herald, 7 November 1990, section 2, 1 .

Describes how the results achieved by the All Blacks affects the spirits of both the team and the well being of New Zealand. Outlines the history of rugby in New Zealand and comments on the results of New Zealand touring teams overseas. Leigh argues that Rugby became the cornerstone of our fragile self esteem and warns that there is no point in expecting continual success as just when we feel we are safely and permanently recognised as the master race of rugby, the All Blacks lose. Reason for meglomania is because when foreign teams beat the All Blacks they trumpet the fact and shame you with it for years.

\section{L23}

Lewis, Ken. "Cracking Down on Sportsfield Thugs." New Zealand Herald, 6 Oct 1999, A15.

Assault on the field of play is now more likely to result in legal blows off the field with offenders facing the prospect of jail terms. The Hillary Commission surveys show that our tolerance for sport related violence is declining.

\section{L24}

Logan, Innes. "All Blacks Not Racist." Sunday News, 22 December 1996, 56.

Former All Black Va'aiga Tuigamala was shocked to discover he has been accused of labelling All Black and New Zealand rugby as racist and that he suggested he and other Polynesians were exploited.

\section{L25}

Logan, Innes. "Michael Jones All-Time Greatest?" New Zealand Sport Monthly, March 1997, 13.

Presents an interview with rugby player Michael Jones. Included is a description of Jones by All Black coach John Hart as well as expressing views about rugby football and racism while also talking about his friendship with Jonah Lomu. 
Lynch, Anthony. "Otago 17 - Southland 11 : A Social History of Otago Rugby in the 1940s." University of Otago, 1984.

Thesis presented in partial fulfilment of the requirements for the degree of B.A. (Hons) in history at the University of Otago. Lynch examines what rugby meant for the people of Otago in the 1940s. The thesis is divided into two distinct periods- the war years and the Shield era. The first chapter examines the impact of the war on rugby in the province and the response of the Otago Rugby Football Union, the clubs and players to the difficulties of wartime rugby. The final chapter looks at the Shield era of the late 1940s, hailed as a most formidable period for Otago. The middle chapters look at the players, administrators and coaches and the common elements that the two distinctly different periods shared. The rituals that surrounded the game are explored. Thesis includes use of oral sources and interviews.

M1

Macbrayne, Rosaleen. "Refs Show Red Card to Constant Abuse." New Zealand Herald, 23 May 2003, A13.

Fed-up volunteer referees are walking away from their sport as regular verbal abuse occasionally boils over into violence. The New Zealand Rugby Union is planning a referee survey this year that could show the extent of the problem.

M2

Macdonald, Finlay. The Game of Our Lives. Auckland: Penguin Books, 1996.

Rugby is used as a metaphor, defining and describing the good and the bad of New Zealand society. The TVNZ television series upon which this book is based set out to look at New Zealand's social history through rugby. The book is peppered with anecdotes of several generations of rugby players, fans and detractors. This is neither a definitive social history, nor exhaustive rugby history, rather this is one version of how a game and its country shaped each other.

It looks at the relationship of South Africa and New Zealand, tinged with pain and hatred. Also includes the "No Maoris - No tour" movement and examines the lifting of conformity in New Zealand 
society. Macdonald scrutinises the myth of racial harmony in New Zealand and the development of the protest movement.

Macdonald also covers the shift from rural to urban society and the Pacific Island players making their mark on the New Zealand game. Other themes the book captures is the disparity of wealth amongst the rugby community and the glamorisation of the rugby player where the marketing society's fragmentation into niche markets actively conspired against rugby's once common appeal.

M3

MacDonald, Finlay. "We Are Sailing." New Zealand Listener 171, no. 3102 (23 October 1999): p5

Comments on events and things that improve the morale of New Zealanders as in New Zealand's rugby win over England and also discuss susceptibility of New Zealanders to the mass suggestion of patriotic fervour.

\section{M4}

MacDonald, Finlay. "Injury Time." New Zealand Listener; 171, no. 3105 (13 November 1999): 7.

MacDonald discusses the implication of the New Zealand All Blacks rugby football team's loss in the 1999 World Cup championship on the economic conditions of the country. Other issues touched upon were the effect of the loss on the team's sponsorship deal with Adidas and investigates factors that contributed to the team's poor performance. The team's game plan and the leadership style has parallels with the economic policies of the government.

\section{M5}

Mackenzie, Morrie. Black, Black, Black! Auckland: Minerva, 1969.

Mackenzie criticises the New Zealand Rugby Union over their refusal to invite to their jubilee nine All Blacks who had played rugby league. Also laments that Ron Rangi was being barred due to previous infractions of discipline. The virtues of amateurism are praised while criticising the rugby hierarchy for sweeping the issue under the carpet. The game had become more violent than the past and 
violent incidents in different eras are compared.The problem of ominous trends with violence and brutality of rugby putting off future generations of players. The style of the All Blacks "bodily contact" game is traced back to the 1956 victorious series over the Springboks and gives an explanation of how key games influenced the style of New Zealand towards forward domination which contrasted with their traditional running style. Mackenzie expresses concern at the continuance of this "brutal" style. The author provides a critical over-view of the French tours of 1961 and 1968 where he believes France has the skill and style to beat New Zealand if it doesn't get fooled into playing the power game and keep their discipline. Chapter 8 examines the decline of British rugby with the 1966 Lions tour. The 3-4-1 scrum comes under heavy criticism for providing the means to which villainy can take place. The Brownlie and Meads sending off is compared and while Mackenzie believes that the referee made a mistake he defends the integrity of the referee. He also casts a critical eye over the selection process of the All Blacks and the merits of having a coach.

The increasingly commercial outlook of the NZRFU is attacked with too many big games being organised to bring in revenue while ignoring the juniors and ordinary club players. He suggests a Wednesday half holiday for mid-week recreation. He also argues that professionalism leads to debased standards of sportsmanship.

Mackenzie warns that the sport of rugby is doomed unless certain reforms are undertaken now. He makes a case for the re-development of Maori rugby to international status as well as praising their contribution to New Zealand rugby.

Mackenzie reserves some of his harshest criticism for the International Rugby Board (IRB) claiming that the organisation has done nothing for New Zealand.

M6

Mackey, Bailey. "Politics - a Threat to Mäori Rugby." Tu mai: offering an indigenous New Zealand perspective, no. 31 (2002): 32, 34.

Uncovers the dissension between the New Zealand Rugby Football Union (NZRFU) and South Africa, New Zealand and Australia Rugby (SANZAR) and then points out how it affected the scheduling of the Mäori All Black game in 2002. 
MacLean, Malcolm. "From Old Soldiers to Old Youth: Political Leadership and New Zealand's 1981 Springbok Rugby Tour." Occasional papers in football studies 1, no. 1 (1998): 22-36.

The campaign against the 1981 Springbok Rugby Tour can be seen as a measure of New Zealand's post-war change driven by and contributing to the disruption of the certainties of nation. The 1981 tour was not simply a struggle for political leadership between the depression/war generation and the baby-boomers or 68ers. Rather it was brought about by the old assumptions of nation and masculinity being weakened in the face of the politics of identification. This paper employs a historicized analysis of youth and investigates protest leadership and participants to argue that the generation that took control of Aotearoa/New Zealand in 1984 were isolate from the popular movements of the 1970s and 1980s and exploited the language of identity politics to protect and ensure.

M8

MacLean, Malcolm. "Of Warriors and Blokes : The Problem of Maori Rugby for Pakeha Masculinity in New Zealand." In Making the Rugby World : Race, Gender, Commerce, edited by Timothy and John Nauright Chandler, p 1 - 26. London: Frank Cass, 1999.

There was no uniform policy of racial exclusion when it came to rugby in the settler society of New Zealand, with Maori playing rugby from its beginnings in the 1870 s. However despite the appearance of Maori in All Black teams, Maori were not included on an equal basis and the cultural appropriation of Maori symbols was used in establishing New Zealand as different from the 'mother country' (England) and distinctive from other settler dominions.

Reference is made to Jock Phillips' article, in restricting his study to Pakeha men he is unable to expose the contradictory position of Maori within many of the iconic sites of Pakeha masculinity and a hegemonic national imaginary.

MacLean asserts that despite the early role of Maori in New Zealand rugby, the hegemonic image of the New Zealand man excludes Maori. His objective is to expose this contradiction between Maori men as gendered female by colonialist discourses while they play a key part in the maintenance of the tools of

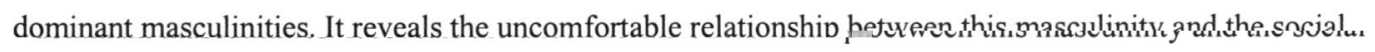
conditions of a colonial state.

Maori relationships with rugby is considered in three aspects: (1) the use of rugby in Maori contexts. (2) consideration of Maori rugby in colonialist discourses through issues such as the legitimacy of warrior rugby and (3) the suggestion that the adoption of rugby by Maori is a sign of their civilisation, that it leads to the removal of a lack thereby enhancing the contemporary hegemonic norm as naturalized, that 
assimilationist policies work, and as a factor in giving New Zealand the "best race relations in the world". In particular the article considers attitudes to Maori rugby in popular discourses through sports journalism and the first New Zealand rugby tour to the United Kingdom in 1888-89.

M9

MacLeod, Alexander. "Roots of Protest." New Zealand Listener 70, no. 1695 (1972): p3.

Looks at the proposed 1973 tour of NZ by SA and takes a measured view of the protest groups and how they will break the law in pursuit of its objectives. Anti-tour activist Trevor Richards dissociates HART from those who have threatened to use explosives and other violent methods to prevent the tour. South African rugby chief Danie Craven's response was "we are coming, bombs or no bombs". Rugby authorities proved insensitive to moral arguments while the government was at fault for standing beyond international consensus. Article concludes that the real threat to order begins not in the protest movement but in the assumptions and actions of those who place rugby too highly in their scales of priorities.

M10

Male, Kevyn. The Rugby Post: Rugby's Place in Heartland New Zealand. Auckland: Penguin Books, 1999.

Light hearted tribute, beautiful photographs of rugby posts over New Zealand capturing the spirit of heartland rugby, the grounds and the personalities. Provides iconic images of 'grass-roots' rugby.

\section{M11}

Male, Kevyn. Coast to Coast - the Grass Roots of NZ Rugby. Auckland: Penguin, 2000.

A snap shot of the heart of New Zealand rugby and the rugby that is played and loved by thousands of kiwis far away from the corporate boxes and big sponsors. An affectionate look at the players and supporters of rural rugby, seen as the last bastion of traditional amateur rugby. 
M12

Manley, Alan. "Antidote to Depression: Rugby and New Zealand Society 1919-1939." University of Otago, 1991.

A thesis presented in partial fulfilment of the requirements for the Post Graduate Diploma of Arts in History at the University of Otago. The style and success of the Invincibles tour of the UK and France of 1924/25 promoted and extended the popularity of rugby football and reinforced the special place that sport had in New Zealand society during the interwar period. From an Otago perspective Manley looks at the issues and attitudes to rugby in New Zealand during the interwar years which includes the depression, the Invincibles tour of Britain and France and visits from touring teams such as the 1921 and 1937 Springboks and the Lions of 1930. Chapter 1 looks at the extent of rugby's popularity and the state of the game in general. Chapter 3 is grounded in sociology and explains why rugby was popular and remained the national game. It looks at the idealised notions of rugby at the turn of the century and sees how they held up to reality of New Zealand experiencing the crisis of the Great War and Depression. Chapter 4 examines the egalitarian nature of rugby in Otago and chapter 5 looks at the question of sportsmanship and conduct of players and ruling bodies of rugby, including lower grade players' attitudes to fighting.

M13

Massey, Murray. "How Rupert Murdoch Tied up Rugby Union." BRW 17, no. 35 (1995): 62-64.

Details the Rupert Murdoch-backed formation of the South Africa, New Zealand and Australian Rugby (SANZAR) heralding the professionalization of the rugby football sport. Includes comments from Dick McGruther, president of the Queensland Rugby Union and looks at the deal between SANZAR and Rupert Murdoch's News Corp. Includes critics on the professionalization of the sport who argue that the money will destroy the special ethos the game enjoys.

M14

Matheson, John. "Money Talks, Players Walk." NZ Rugby World, November 2001, 13.

Professionalism is affecting the transfer and release of players as with the case of Paul Steinmetz and Byron Kelleher, professional players now deciding on what team to play for depending on the size of the pay cheque. 
M15

Matheson, John. "League Fighting a Losing Battle." NZ Rugby World, May 2001, 24-25.

The rivalry between Rugby Union and league is discussed and states there is no doubt that rugby union with the advent of the Super 12 and Tri Nations has moved way ahead of league in recent years. Some league administrators are so worried that they are now openly supportive of rugby and league joining forces and merging.

M16

Matheson, John. "Give a Brother a Chance." NZ Rugby World, June 2001, 16-17.

New Zealand Rugby has a close relationship with the Pacific Islands and Matheson argues that New Zealand must do all it can to help Pacific Island rugby and laments the hard fast rule of the IRB that allows a player to play for only one country. Eligibility needs to be cleared up but special allowances should be made for the islands when talented players of Polynesian ethnicity are not wanted or needed by the All Blacks.

M17

Matheson, John. "Time for a Cuppa..." NZ Rugby World, April 2001, 19.

Criticisms are directed at the attitude of New Zealand professional players from the public through talkback, former players and media personalities. The conclusion is that the drop in standards is due to the player drain which New Zealand rugby was now beginning to feel the effects.

M18

Matheson, John. "So What's the White Answer?" NZ Rugby World, October 2001, 20-38.

With Polynesians dominating New Zealand rugby, where have all the white rugby players gone? Soccer seems to be a beneficiary of white flight and mothers concern that their kids are going to get a hiding from the bigger, stronger Polynesian kids. Other reasons are seen to be the influence of play-station 
and $\mathrm{x}$ box and the preference for faster maturing Polynesians at junior level that leave non-Polynesians ignored on the sideline. Also investigates the effects of professionalism within the Polynesian community and the increased pressure from families on children so the whole family can get rich. The issues extend to administrative levels where the majority of players are brown yet very few are involved with coaching or administration.

\section{M19}

Matheson, John. ""PR Wank" or a Fix It?" NZ Rugby World, February-March 2002, 16-17.

Matheson looks at the importance of rugby's first official collective employment contracts to combat the player drain to rich overseas clubs and asks how good is this for the players? The upside is protection for professional players through personal grievance procedures and guaranteed minimum conditions of employment, supplemented with measures to deal with ill or injured players and develop other careers and the downside being the players curtail their ability to strike.

M20

Matheson, John. "Our Cup Runneth Empty." NZ Rugby World, May 2002, 18-19; 23-25; 27; 29-31.

Article looks back at the loss of sub hosting rights to the 2003 Rugby World Cup. Key players involved being IRB chief Vernon Pugh, NZRFU chairman Murray McCaw, chief executive officer David Rutherford, Deputy CEO Steve Tew, Australian CEO John O'Neill and New Zealand IRB representative Rob Fisher. Matheson chronicles the breakdown in relations between the NZRFU, the ARU and the IRB. The conclusion highlights the loss of potential revenues for New Zealand and accuses Rutherford and McCaw of incompetence and indulging in brinkmanship.

\section{M21}

Matheson, John. "We Need a Plan." NZ Rugby World, June 2002, 10-11.

Matheson calls for patience after the World Cup hosting debacle but demands that the NZFRU's board needs a complete overhaul. Criticisms include charges that the NZRFU has become too insular. 
M22

Matheson, John. "More Should Fall under the Weight of Sir Tom's Thumb." NZ Rugby World, August 2002, 14-15.

Why, after the Eichelbaum report that investigated why and how New Zealand lost the rights to sub-host the 2003 World Cup, has there not being enough real change in the NZRFU. Attention focuses on Rob Fisher and Steve Tew while also criticising the hiring of a PR company to help manage the fallout.

M23

Matheson, John. "Player Welfare the Burning Issue." NZ Rugby World, August 2002, 16.

The issue of player burnout is a significant problem. Rob Nichol, New Zealand Players Association head argues for a 12 week break between seasons.

M24

Matheson, John. "Rough Justice as Cribb Moves to Take Court Action." NZ Rugby World, April 2002, 16-17.

With the impending court action between Ron Cribb and the NZRFU over the refusal to pay his full All Black contract monies, Matheson looks at other legal wrangles and the influence of the player agent.

M25

Matheson, John. "Kamo's Plea to NZRFU." NZ Rugby World, September 2002, 14-15.

Matheson talks to former All Black lock Ian Jones who argues that the New Zealand outgoing rugby administration maintained a head in the sand attitude regarding New Zealanders playing and coaching in the UK, France and Japan. When a player departs overseas the union closed the door on them and believes this attitude stems from an old fashioned belief that the NPC and Super 12 was much stronger than rugby competitions in the UK. Jones recalls his overseas experience acknowledging the huge amount of knowledge he gleaned from an assortment of international players and argues that the Super 12 would benefit having an injection of overseas personalities and the NZRFU should make an attempt to keep in contact with New Zealanders playing overseas as they still had an enormous amount to offer 
M26

Matheson, John. "A Man's Corporate Legacy - Lest We Forget..." NZ Rugby World, December 2002January 2003, 9.

Tribute to an independent member of the NZRFU board Kevin Roberts who masterminded the replacing of Canterbury's sponsorship with a $\$ 100$ million Adidas contract thus ensuring the future of the game in New Zealand.

M27

Matheson, John. "The Word from HQ." NZ Rugby World, December 2002- January 2003, 68-77.

The NZRFU tell their own story about the state of the game in New Zealand from key figures such as chairman Jock Hobbs, President Lane Penn and Vice-president Tane Norton. Focus is put on the new NZRFU web initiative designed to assist provinces as well as club and college teams. Hobbs explains the role of the NZRFU in ensuring that rugby continues to be a dominant sport in New Zealand, and also gives his opinion on how New Zealanders react to success.

M28

Matheson, John. Christian Cullen: Life on the Run. Auckland: Hodder Moa Beckett, 2003.

Biography of All Black fullback Christian Cullen and describes his fall-out with All Black coaches John Mitchell and Robbie Deans and details getting enticed by Irish province Munster to play for them and leaving New Zealand.

M29

Mawdsley, Craig. "Franchise Free Agency and the Rugby Super 12." University of Waikato, 1999.

A thesis submitted in partial fulfilment of the requirements for the Bachelor of law (Honours) in the University of Waikato, Mawdsley investigates the development of professional rugby in New Zealand 
and the events which led to the adoption of the franchise format for administering the Super 12 competition. He considers the characteristics of sports franchise, identifying the essential elements that distinguish the sports franchise from other types of franchises.

M30

McCarthy, Winston. Haka the All Blacks Story. London: Pelham Books, 1968.

Tells the story of the All Blacks from their origins to the 1967 tour to the British Isles, France and Canada. Looks at how the game was started and subsequently flourished within New Zealand, McCarthy explains how the New Zealand Rugby Union was founded and looks at the early international visitors to New Zealand. There is a chapter devoted on the 1905 team that became known as the "All Blacks". "The trying years" examines the threat of professional league on domestic rugby and the arrival of the AngloWelsh team in 1908 who encountered rough play and regarded the New Zealand position of wing forward as "an obstruction...and is always off-side". Also looks at the Kings Cup and services rugby.

"The Golden Twenties" is seen as a halcyon era for New Zealand and looks at the "Invincibles" tour and the Cyril Brownlie sending off against England in 1924.

The great Hawkes Bay Ranfurly Shield team occupies the attention of chapter 8. Chapter 9 lauds the 1928 tour of South Africa and the 1930 Great Britain team. The author also focuses on the abolishing of the two fronted scrum and the shambles that resulted from the readjustment to conform with international opponents.

M31

McConnell, Christopher (Kit) David. "The Changing Face of Sport Management. A Study of a Provincial Rugby Union Facing Professionalization and Corporatization." Massey University, 1996.

Examines the management of New Zealand rugby at the elite provincial level to determine the profile of people involved and the manner in which elite provincial unions have been affected by professionalism and corporatization. The historical forces shaping rugby management, particularly the ethos of amateurism and professionalism are examined 
McConnell, Lynn. "Who Has the Power? Rugby Politics." New Zealand Sport Monthly, no. 47 (1996): 21.

Examines recent changes in the structure of the New Zealand Rugby Football Union, and questions whether these have made the organisation any less parochial.

M33

McConnell, Robin. Iceman : The Michael Jones Story. Auckland: Rugby Press, 1994.

Biography of Michael Jones, a highly regarded rugby player and part of the new breed of brilliant Polynesian rugby players who started his international career with Western Samoa first before playing for the All Blacks. Made the open side flanker position his own from 1987 to 1994 and then converted to the blindside flank position where he played until his retirement in 1999. Describes his childhood growing up in West Auckland in a burgeoning Polynesian community and his development into becoming a highly respected player.

M34

McGee, Greg. "New Age Warriors." New Zealand Listener 155, no. 2942 (14 September 1996): 24-25.

Cites on the cuddling of All Black and Highlanders player Jeff Wilson by Gordie Hunter, coach of the New Age, that suggests signals the end of rugby's macho image in New Zealand. Looks at the physical violence of rugby and the traditional machismo image of rugby players.

M35

McIlraith, Matt. "Telecom 2go Interview : David Rutherford." Rugby News, March 1-7, 2000, 8-9.

An interview with David Rutherford, newly appointe CEO of the NZRFU. His appointment was seen as a return to the traditional values of the game. Amongst other things Rutherford gives his views on his vision for New Zealand rugby in 2003, his plans to assist the development and promotion of club rugby and the planning for the co-hosting with Australia of the 2003 World Cup. 
McIlraith, Matt. "Do We Really Want a Global Game?" Rugby News, July 5-11 2000, 2.

The impending talks amongst SANZAR partners had South Africa and Australia mooting an expansion but New Zealand is not interested in enlarging the Super 12 tournament if it doesn't suit or advantage New Zealand. While that attitude has some merits it casts doubts on the viability of a global season which the IRB say they want and what countries like New Zealand have supposedly supported. Major nations are all guilty at not addressing the issue because it will not necessarily benefit them.

\section{M37}

McKewen, Trevor. Real Men Wear Black. Auckland: Rugby press, 1994.

McKewen gives tribute to rugby and league players who were known for their hardness and ability to play through the pain barrier and best exhibited the staunch machismo that has made the black jersey so feared. The chapter on Buck Shelford explains his attitude to sorting out nonsense on the field and justifying initiating violence on the field. Shelford also gives a critical appraisal of where the All Blacks went wrong in the 1991 World Cup pointing to the impact of television and coverage of leagues Winfield Cup that pressurised the team into playing an exciting style. Colin Meads recalls injuring Ken Catchpole and getting his arm broken while touring South Africa. Meads is concerned with players attitudes in the modern era and laments the demise of club rugby and feels there is an overreaction to league and that the future direction if rugby is been governed by reports that are prepared on the basis of what other sports are doing. Frank Oliver explains his reaction to seeing players getting kicked in the head and when he has had to resort to violence and recalls his clash with Jimmy Young in South Africa 1976 and the violent Lions Manawatu 1983 match and how there was no kicking in his day. Kevin Skinner remembers the atmosphere of having to sort out and defeat the Springboks in 1956 and details his clash with the Springbok front row and the media reaction to this. He gives an insight into the public expectation and pressure on the All Blacks to defeat the Springboks. Mark Shaw was a player whose reputation preceded him as an enforcer and hit man who had no qualms about belting trouble making opponents including Eben Jansen and Steve Williams. He gives his reaction to the cancellation of the 1985 South African tour and undertaking the Cavaliers tour and gives his attitude towards the anti tour perspective and argues that rugby is being singled out unfairly over its contact with South Africa. 
M38

McLean, Terry. All Black Magic: The 1967 Tour. Wellington: Reed, 1968.

McLean celebrates the attacking attitude of the 1967 All Blacks and rates them up with the immortals because they picked up the ball and ran with it which was a change in style for New Zealand as rugby pre 1967 had principally become a dull physical contest for almost 2 decades.

With their ploys and plans and above all their passing, the 1967 All Blacks administered a boost to the game. New Zealand rugby had been driven since the late 1940s by a philosophy of favouring defence over attack. In the years that followed New Zealand rugby was admired but not loved characterised by 55 yards Rugby, strenuous, toiling forward play, fine goal kicking, a studious, zealous, unfaltering adherence to a pattern of attack.

McLean makes a comparison between previous All Black tourists to the United Kingdom and Ireland, heralding the return of attacking rugby that characterised in particular the 1905, 1924 and the 194546 'Kiwis'. In terms of endeavour, the 1967 team can stand with the best of previous touring teams.

In chapter 2 McLean examines on-field discipline and how referees handle rough play. The clash of techniques, philosophies and styles made the All Blacks a target for referees from the Home Unions. He examines other notable incidents from previous years where New Zealand was involved in unsavoury episodes. From this discipline the management was able to set in motion the true attacking brilliance of the New Zealanders.

McLean examines in depth the Meads sending off and provides a balanced view, which is sympathetic to the referee. McLean sees the style in which the All Blacks played as the end of the beginning (of forward obsessive rugby devoid of running).

M39

McLean, Terry. All Black Power. Wellington: AH \& AW Reed, 1968.

The 1968 season saw New Zealand tour Australia and France tour New Zealand. Three things were common to the 1968 season- rough play, indifferently skilled attempts at running rugby and refereeing which excited criticism. The authorities must recognise that rough play is the sick side of rugby and international competition is acquiring the atmosphere of a professional rather than amateur activity. "Neutralism and all that" captures the ill discipline and violence of the French tourists. 
McLean, Terry. Red Dragons of Rugby. Auckland: AH \& AW Reed, 1969.

A record of past matches of the All Blacks in Wales with the focus on the 1969 Welsh tour of New Zealand. "Rocking the rugby world" examines why Colin Meads broke the jaw of Welsh hooker Jeff Young.

\section{M41}

McLean, Terry. Battling the Boks: The 1970 All Black Tour of South Africa. Wellington: Reed, 1970.

McLean admits that covering the tour as chief rugby writer for the Auckland Herald he became affected by several events. Rugby violence was extremely severe in the second test and the Eastern Transvaal match where Meads received a broken arm from a deliberate kick. More significantly McLean discusses the controversial contact with apartheid South Africa. "There was no escape from the responsibility. One could not hope to write a reasonable accurate account of the tour without placing it in perspective to the struggle, which was going on in the development of South Africa."

All Blacks made many mistakes, which were capitalised by the Springboks. Suicidal errors in handling, poor tackling, tactical plays even backing up were inferior. McLean looks back at the rugby relationship between the two nations where racism has been present and the gradual development of a protest body including the issue of "no Maoris no tour". McLean surveys the political landscape of international sport. He also discusses the attitude of blacks and coloureds to the All Blacks who enjoyed their support. The All Blacks, inflated by their success in the provincial games became less hard-nosed, as if they believed their own press and became inflicted by over-confidence.

Bryan Williams who is part Samoan was the superstar of the tour with his elusive powerful running and side-stepping. McLean's verdict on style was that the All Black's in losing the war won the battle which was the sort of rugby that ought to be attempted by all teams at all levels. However he believed that it was essential that leaders should recognise that the New Zealand game contained some deficiencies, which needed urgent repair and touches upon the pressures on rugby from rival codes such as soccer. He explains the effect of the heavy defeat from the Springboks on New Zealand's tactical thinking. From attacking, back play had become principally a supporting force because New Zealand lacked a world class backline and had to rely on forwards. They were the best but the clash in forward play tended to engender rough play. In the chapter "Into the future" McLean ponders on the violence of rugby and looks at the Sid NomisFergie McCormick clash where the fullback's elbow broke several teeth of the Springbok player.

An argument for neutral referees is made and looks ahead to the 1973 tour and the growing movement that opposes contact with apartheid South Africa. He looks at the background politics concerning multi racial 
rugby and social conditions in South Africa. The conditions South African President Vorster set to allow Maori players to tour in 1970 was that there should not be too many Maori and they should not be too "black".

McLean criticises New Zealanders who sneered and belittled their countrymen who objected to sporting relationships with South Africa and examines the human side of apartheid, the tensions it creates for citizens in South Africa and what chance for redemption for that nation.

\section{M42}

McLean, Terry. Lions Rampant; the Lions Tour in New Zealand 1971. Wellington: Reed, 1971.

McLean reviews the historic 1971 Lions that became the first British team to defeat the All Blacks in a test series, as well as commentating on the state of the game within New Zealand. Amateurism and its nemesis professionalism are compared and touches upon the hostility between administration and the public and between the administration and news media.

His report contains criticism from British experts that the New Zealand game is too fixated upon the forward encounter, which British forward play had moved ahead of the New Zealand style in technical proficiency. Because the New Zealand game was too physical not enough latitude was allowed for natural genius to express itself in back play. New Zealand as a rugby nation had been at fault for accepting too low a standard of coaching.

The Lions conception of law and order was stronger than New Zealand thus discipline was a major strength. New Zealanders regarded this as part of psychological warfare on the part of the Lions. There was criticism of New Zealand rugby accepting widespread and consistent breaches of laws affecting contact play.

For the first time in the association of Lions and All Blacks, the New Zealanders were discovered to be inferior in most of the vital particulars of good rugby. The weakness in the New Zealand game is expanded upon with main reasons seen as passing and tackling, lineout shambles, bad scrummaging, kicking in the backlines, inferior place kicking and addiction to ploys based entirely upon the setting up of second phase plays. However it is never possible to be too sure about anything as New Zealand made more of an attempt to play 15 man rugby.

Criticism of New Zealand coaching included the charge that the importance of body contact play by the forwards had become misunderstood and minimised. Perhaps because of too much success in the past New Zealand had forgotten that the first simple duty of forwards is that they be forwards in the true sense. McLean looks at Rugby's position in New Zealand society, acknowledging that other sports are beginning to eat into rugby's popularity. He comments that "it is dismaying and disturbing to the New Zealander that after generations of success the New Zealand Rugby Union has become too slothful to fight with the zest 
and energy of old." (P 57) Further criticisms of the New Zealand Rugby Council, few who were prepared to attack the abuses in the game. The public has been disenchanted by the inflexible attitudes of Council on two matters of profound importance- the direst telecasting of matches and the issue of violent play and the intense style of the New Zealanders that has damaged their reputation in the eyes of some. The erosion of support from rugby was slow to be picked up by the New Zealand Rugby Union and includes their reaction to the declining numbers. McLean saw as tragedy not that Maori rugby existed but that it had become tainted by whiteness by Pakeha and also by Maori mismanagement and so had lost its true Maori characteristic. The growing numbers of Pacific Island players within New Zealand is cited as a problem. McLean warns of an increasing antagonism between the Australian and New Zealand Rugby administrations.

Chapter 11 looks at how the British regarded our rugby with transcript of a discussion with John Dawes the captain, Carwyn James the coach and Smith the manager.

M43

McLean, Terry. They Missed the Bus; Kirkpatrick's All Blacks of 1972/73. Wellington: Reed, 1973.

McLean gives his view on the controversial 1972-73 All Blacks tour of Britain, Ireland and France. The 7th All Blacks became the worst team New Zealand has ever sent to the British Isles because they were ill managed, ill coached, and ill led.

McLean chronicles and explores the ill discipline that racked the team starting with the background of the justification of the appointment of the coaching staff, Bob Duff who strove in large part successfully to check the disintegration of New Zealand tight-forward play.

Recent criticisms of the New Zealand game from British experts are revisited. John Dawes, successful Lions captain in 1971 posed the question that in the 1970s several nations had moved ahead of New Zealand and whether New Zealand had the wit to catch up while comparison is made of the 1972-73 team with previous All Black teams to the United Kingdom.

When Fred Allen was replaced by Ivan Vodanovich as coach many All Blacks were persuaded that forwards who ran the ball were more dangerous than forwards who won it. New Zealand forwards had forgotten, that forwards risk all when they forget that they must be, primarily, suppliers of hard won ball. The performance of the forwards on the tour are closely examined in chapter 8 Humiliated Were They? But it was the back play that is largely lamented. McLean forcasts that British rugby was to become the new power house in the international arena.

The problem of dirty play is explored in chapter 9 Vive la Difference.

McLean looks at the development of "professional coaching" and its clash with the much touted virtues of amateurism in Yesterdays Children and illustrated the strains of professionalism that pervade New Zealand. 
The media portrayal of the tour was chronically handicapped by insinuations and excoriations in the English and Welsh press, antagonism directed towards the All Blacks and illustrates the All Black 1972-73 style and limitations to this effect. Their main topics seemed to be the "trampling" of the All Blacks and their campaign against Sid Going who comes in for a little criticism as being too much of an individual to be an effective leader. McLean contrasts this attitude with previous tours. The Keith Murdoch affair is given its own chapters $11 \& 12$, in the latter McLean compares the states of hysteria in Wales 1972 and New Zealand 1956 when they hosted the Springboks.

M44

McLean, Terry. All Blacks Come Back: Terry McLean Looks at New Zealand and World Rugby. Wellington: Reed, 1975.

Terry McLean looks at the state of New Zealand and World Rugby during 1974 which were highlighted by the short tour of Ireland and "test" matches against a Welsh XV and the barbarians in late 1974 which marked a dramatic turning point in the fortunes of New Zealand Rugby which had been in the doldrums in the early 1970s. There had been defeats by the Springboks in South Africa and by the touring Lions and Englishmen at home then the ill fated tour of Britain in 1972-73 which proved a public relations disaster.

The author who observed the 55-yard style favoured by the All Blacks of the 1950s and early 1960s, through to the ideological epitome of 15-man rugby appraises the style of the All Blacks. The 1974 All Blacks managed to break the shackles of defensive play, and the inspirations and encouragements of their play, should shake up the rugby not only of New Zealand but also of all nations. While the play of the All Blacks was described as a new look, McLean notes that this was the style played by New Zealand teams before the 1950s and foresees within New Zealand a more intense awareness of the need to guard the known qualities of the game while consistently prospecting for finer qualities and infers that the coaching ideas in the British Isles was concentrated upon defence as the first requirement of success. While New Zealand rugby appeared to be in a slump, they demonstrated a greater capacity in attack.

McLean discusses world rugby at large, particularly the South African 1973 tour of New Zealand that had been cancelled, examining the attitudes and behaviour of the NZRU in their relationship with South Africa. McLean ponders on the problem of violence affecting rugby throughout the ages and the world and touches upon the difficulty experienced by the 1972-73 team including the antagonistic barbs from the press and laments the deterioration of attitudes that affect rugby. Leadership was seen as one of the main reasons for the return of a successful All Black team. Improved discipline enabled the team of 1974 to break down large barriers of hostility and restored substantially if not totally the unparalleled image which New 
Zealand holds in world rugby. In conclusion McLean asserts that a return to traditional discipline and a willingness to play open attacking rugby restored New Zealand's reputation on and off the field.

\section{M45}

McLean, Terry. Goodbye to Glory: The 1976 All Black Tour of South Africa. Wellington: Reed, 1976.

McLean provides a political lead up to the tour, and profiles the growing protest movement, while painting a background of the Olympic boycott of African nations. Though McLean was pleased that after the disasters of 1970-73 the surgery on the All Blacks brought pleasing results, the limitations of the All Blacks with problems with discipline were exposed.

Stewart encouraged players to contribute their theories on the way to play rugby. However the principles of freethinking and free speech that were encouraged, turned around and bit them. Too many All Blacks on the field complained about penalties and incompetent refereeing. This reflected a weakness in team discipline.

One of the greatest tributes to the 1976 All Blacks was that in spite of all criticisms that at forward they were not what New Zealand used to field and that they compared indifferently with their predeccessors of 1970 , they fielded, in fact, a pack which was superior in pretty well all the games. This was one of the great contributions John Stewart made to New Zealand rugby. Coming in after the defeat in 1971 to the Lions, he concentrated the attention of forwards on basic techniques. They responded admirably and the best pack of 1976 would be hard to beat.

In chapter 6 Riots, Rucking, Refereeing McLean describes the two events which in his opinion helped to explain why, at the end of it, the bulk of the New Zealand public had switched from support to opposition to sporting relationships with South Africa: All Blacks caught in a race riot and the stomping by Moaner van Heerden on Peter Whiting.

McLean asserts the All Blacks and world rugby were unlucky that they did not deliver their potential as their style was more attractive and praised the All Black's attempt to play running rugby.

With the issue of hard and rough play in rugby, McLean believed that a cure would be the emphasis of the 15 man game rather than brute strength. McLean compares the violence of the 1976 tour to previous tours and notes the disgruntlement towards the South African referees and press. The author looks at the aftermath of the tour with its effects on sports policy in South Africa and the practical implications while offering a sliver of hope for the future. McLean touches on Black consciousness and the build up to the Montreal Olympic boycott. 
McLean, Terry. Great Days in New Zealand Rugby. Auckland and London: Fontana Silver Fern, 1976.

An account of 22 historic matches played by or among New Zealand teams. Starting in 1897, the year a Wellington team, having played Otago, was stoned and called "Butchers". Described as the greatest match of all, the 1905 All Blacks versus Wales reopens the Deans no-try controversy. The 1921 Maori v Springboks match prompted a South African reporter to lament that the Europeans in the crowd cheered on coloured men to defeat members of their own race. McLean examines this controversy in great detail, and the consequences of the leaked cable. In Triumph and Disaster he looks at the 1925 New Zealand All Blacks match against the English where Cyril Brownlie became the first international player to be sent from the field. The Battle of Solway recalls another legendary violent match Wairarapa v Hawkes Bay 1927. In 'The Year of Eruptions' the violent 3rd test NZ v SA 1956 is revisited. 'They Killed the Critics' sees the rebirth of the All Blacks in Wales 1974 where there style and good behaviour helped restore the image of the All Blacks after their public relations disaster in 1972-73.

\section{M47}

McLean, Terry. Winter of Discontent : The 1977 Lions in New Zealand. Wellington: A.H. \& A.W. Reed, 1977.

McLean examines the 1977 Lions tour of New Zealand and other significant implications for the future of New Zealand rugby including the growing commercialisation of New Zealand rugby and what New Zealand must do to arrest the dramatic decline in All Black forward power.

McLean also provides an insight into why relations between the Lions and the press degenerated into open hostility and confrontation. He explains that the pressure of performance to match the 1971 Lions proved too much for the 1977 team. Antagonism between the tourists and locals was an unfortunate byproduct with the Lions disappointed with the reaction from local crowds and the public distaste shown towards the Lions. The chapter "of ships and shoes" looks specifically at the bad behaviour by the Lions off the field and aims criticism towards the New Zealand council for their off hand treatment towards the press. The chapter "And discontent lay all around" he questions the style of the 77 All Blacks whose only great contribution to the series was a standard of tackling far beyond anything reached in modern times by All Black teams. He looks ahead to the commercial realities for smaller unions which will be financially crippling. The relationship with apartheid South Africa is described as the 'death watch beetle' of New Zealand rugby and McLean opines that it would be inappropriate to attempt to foster the old All Black Springbok partnership. 
McLean, Terry. Mourie's All Blacks. Auckland: Hodder and Stoughton, 1979.

McLean credits fitness, discipline and spirit as the qualities that brought victory out of defeat during the historic 1978 All Black Grand Slam tour of Britain and Ireland. McLean's verdict places the record of the team as a formidable achievement particularly as British rugby had never been so well prepared to resist an All Black team.

The causes of the change in character of these All Blacks compared with too many of their predecessors in the recent decade were three: management by Russ Thomas; Coaching by Jack Gleeson; and captaincy by Graham Mourie. Each man in his own field was expert.

McLean laments that the last week of the tour was wrought with controversy. Except for a few isolated incidents in the matches against West Wales and Wales the tour before Bridgend had been unequalled, in modern rugby time, for clean play. Then John Ashworth intending to rake the ball, connected with the head of the Bridgend fullback and captain JPR Williams. Crowd hostility towards New Zealand spilled over to an attack by thugs on Russ Thomas the manager. Double standards of the great majority of the UK press annoyed the New Zealanders.

McLean poses the question - was rugby as relevant and important to the New Zealand community in 1978 as it had been in previous years? He passes comment on the gatherings of commercialism and player power and background the difficulty New Zealand rugby faced leading up to the tour.

In chapter 3 McLean weighs up the merits of the running open game versus the tight power play. The All Blacks had opened the tour playing attacking rugby until they lost to Munster where they were forced to reassess and play more conservatively. McLean believed that a want of confidence in their ability decided how they should play the game. He places the fault with the consciousness of the New Zealand public that come whatever victory was of the highest importance. McLean argues that enjoyment should not be lost in the pursuit of victory, and the adventure that characterised early New Zealand teams before World War Two should not be a casualty and points to the 1949 whitewash at the hands of the Springboks as the catalyst that caused rugby to descend into defensiveness. He compares the 1967 All Blacks with their ethic of attack to the 1978 team. The mood of nationalism in rugby is explored and how it affects rugby relationships while a comparison is made with the 1972-73 team and the Ashworth-Williams incident. McLean looks at the world of rugby in 1978 and the increasingly growing strains of commercialism and professionalism, the Gleneagles agreement and South Africa's place in the rugby world. Violent and foul play has lowered rugby's esteem in public eyes with the ruck seen as a source for trouble. McLean worries that the Nationalistic element that the 1976 All Blacks detested in South Africa had surfaced in New Zealand audiences. 
McLean looks over the proud and glorious past that have made Maori rugby a force to be reckoned with. From the early Maori teams that took to rugby as fast as the game spread including the amazing feat of the Natives team of 1888 that played over 100 matches. From the turn of the century to 1982 McLean recalls the highlights and lowlights that decorate the lineage of Maori rugby.

M50

McLean, Terry. "Whither Maori Rugby." Tu Tangata no. 9 (Dec - Jan 1982-83): p 17-20.

McLean looks at the background to rugby's special affinity for the Maori. Seeks to explain why there was a long delay between the second (1926) and third (1982) great Maori tours, politics being the most likely reason. While Maori clamoured for more tours the rugby councillors resisted. Jack Sullivan, chairman of the Council wanted to phase out Maori rugby. Throughout the 70s members of the council were opposed to Maori rugby as a special part of New Zealand Rugby. Article reviews "embarrassments" in Maori rugby such as the 1921 match versus the Springboks where a South African journalist reported that it was "bad enough Springboks having to play a team officially designated New Zealand natives but the spectacle of thousands of Europeans frantically cheering on a band of coloured men to defeat members of their own race was too much for the springboks who were frankly disgusted." [See also M45]

The 1956 team that played the Springboks were humiliated 37-0 and the result helped generate belief that New Zealand Rugby would be better improved if Maori Rugby was phased out. The attitude of Maori to the All Blacks sending teams to South Africa without Maori changed over time, from one of compliance to the status quo to greater politically awareness and objecting to discrimination . Tribalism within Maori ranks was an unfortunate feature, with individual merit sometimes overlooked in favour of internal politics. Also reflects on some Pakeha who resent the continuance of New Zealand Maori teams.

\section{M51}

McLean, Terry. "Maoridom's Mighty Warriors." Tu Tangata Dec-Jan 1982-83, no. 9 (1982-1983): p 5-9.

Terry McLean peruses over the many brilliant Maori rugby players, praises their talent and style while attempting to name a First XV of Maori rugby. 
McLean, Terry. "Concern at Warlike Atmosphere." New Zealand Herald, 2 June 1983, section 1, 10.

McLean expresses disappointment at the warlike atmosphere created before the first test against the Lions. Lions management criticised New Zealand refereeing and expressed abhorrence to the injuries suffered to players in the Manawatu game. McLean questions why no-one in New Zealand rugby has expressed regret over these incidents and recalls incidents of violence concerning Bernie Fraser and John Ashworth.

M53

McLean, Terry. "Fervour and Frustration." New Zealand Listener 110, no. 2374 (17 August 1985): p 31-33.

Extreme nationalism bolsters the Afrikaners' conviction that they alone are the masters of rugby. Springbok vehemence and All Black determination to win make their matches passionate yet dour. McLean tries to provide an explanation the extraordinary passions of so many New Zealanders and white South Africans to see their team win. Frustration is seen as one explanation, the first two series being drawn in 1921 and 1928. From this was manufactured an overwhelming desire of the two countries to subject the other to defeat. "Frustration all too seldom engenders humour; and the want of this has been a sadly consistent feature of all the series" (p 33).

Aspect of this frustration played out in the sole use of Maori place names as a reciprocal speech to hosts who spoke in Afrikaans. Tests between the two nations are always tough to the extreme, fuelled by ultra nationalism. This determination often makes the playing style dull as both sides take a win at all costs attitude that over-rides the desire to play attractive rugby.

M54

McLean, Terry. NZ Rugby Legends. Auckland, NZ: Moa, 1987.

15 reflections on All Black legends by TP McLean. The players that are reflected upon are Tom Ellison, Jimmy Duncan, Dave Gallaher, Billy Stead, Billy Wallace, Jimmy Hunter, Frank Mitchinson, Stan Dean, Mark Nicholls, Cliff Porter, Maurice Brownlie, Bert Cooke, 'Brushy' Mitchell and Charlie Saxton. Their influence on the style and psyche of the All Blacks is well documented. 
M55

McLean, Terry. "All Blacks: The New Zealand Story." Time International (New Zealand edition) 133, no. 23 (1989): 3-4.

McLean provides an overview of the development of rugby in New Zealand, with particular emphasis on the years between 1870 and 1928. New Zealand's relationship with the South African rugby is summarised.

M56

McLean, Terry. "Rugby: Into the Future." Time International (New Zealand edition) 133, no. 23

(1989): $27-29$.

Outlines the history of the International Rugby Board (IRB), emphasising dissatisfaction with its attitudes from member unions This frustration led to the development of the Federation Internationale de Rugby Amateur (FIRA) and membership by the USA and USSR. Article follows the progress in removing apartheid from rugby in South Africa and speculates on a professional future for the sport there.

M57

McLean, Terry. "Rugged, Rough or Disreputable?" New Zealand Herald, 25 July 1992, section 2, 2.

McLean questions the New Zealand Rugby Council's decision not to discipline All Black Richard Loe for misconduct towards Wallaby Paul Carozza, predicting that they will live to regret it as it will strengthen the public belief that there is too much rough play and overmuch tolerance for it. Notable cases of violent play in rugby matches such as the 1971 Canterbury v Lions and the 1956 New Zealand v South Africa third test are back grounded. 
M58

McLean, Terry with Andy Dalton and Ian Robertson with Bill Beaumont. Two Sides to the Argument: All Blacks V Lions '83. Auckland: Hutchinson, 1983.

Ian Robertson BBC Rugby Correspondent with former England and Lions captain Bill Beaumont look at the 1983 Lions tour of New Zealand from a British angle. Terry McLean with All Black captain Andy Dalton offers the New Zealand view point.

They cover every aspect of the tour and contemporary affairs including the allegations of dirty play, bad refereeing, the rucking controversy, the proposed professional rugby circuit and the sad decline of British rugby.

Includes a British perspective into how rugby fitted and shaped the New Zealand social environment and how New Zealand style, while able to be more expansive since the mid 60 s when placed under pressure can revert to the powerful forward play.

The writers offer criticism of violent incidents in early tour matches in particular the Manawatu game. The prospect of David Lord's professional rugby getting established is touched upon.

McLean analyses the style of play from the respective teams making the observation that over coaching had stifled British play particularly the backs. Gives judgement on Lions manager Willie John McBrides criticism of foul play, and looks at the allegation of 'every game in New Zealand is dirty'.

M59

McMillan, John. "Rugby Meets Economics." New Zealand Economic Papers 31, no. 1 (1997): pp. 93114.

Looks upon professional rugby, arguing the right mix of centralization and decentralization must be found, with both coordination from the rugby union and autonomy for the provincial teams. Too much central control could undermine the credibility of the playing-field competition; too little could allow competitive imbalances to arise. For competitive balance, there must be some rules on the movement of players among teams however, these rules should not put an undue burden on the players. 
M60

Mctagget, Sue. "Cez Blazey: Creature of Habit." New Zealand Listener 110, no. 2366 (22 June 1985): p 18-19, 24.

Interview with Cez Blazey, the Chairman of the NZRFU. Gives insight to the man many from middle New Zealand who were against sporting contact with South Africa spit venom at.

M61

Mensah, Peter. "Damn the Critics and Doom Merchants." NZ Rugby World, September 2002, 36-38.

Mensah, a former Harlequins and England B international now residing in New Zealand, is concerned by both media and public reaction to the All Blacks' performance, seeing it as myopic. He reminds kiwi fans that sport does not bow down to reputations, no matter how great. Pre professionalism saw New Zealand utilise natural fitness advantages as players came from farming backgrounds whereas today players are scientifically prepared making little difference between top players. Critics and supporters must get behind the team and appreciate that there is a long term plan to get New Zealand rugby back to the top of the tree.

M62

Mexted, Murray with Alex Veysey. Mexted: Pieces of Eight. Auckland: Rugby Press Ltd, 1986.

Autobiography of All Black number 8 Murray Mexted that reminisces his career with Wellington, Petone and the All Blacks. Themes include playing club rugby in France, shamateurism, playing and living in South Africa, South Africa tour to New Zealand 1981, the cancelled tour to South Africa 1985 and the rebel Cavaliers tour to South Africa 1986. 
M63

Mold, Francesca. "Rugby's Drive into Market Era Hits Fans." New Zealand Herald, 22 Jan 2000, A16.

Investigates concerns that the move to professionalism in rugby is exploiting fans, particularly in the area of replica jerseys. New Zealand should beware a backlash from its own fans. Super 12 jerseys are to be changed every 2nd season but the All Black jersey is "sacred and steeped in heritage" Sean Fitzpatrick said the new jersey designs reflect changing nature of the game that included the need for commercial considerations.

M64

Moore, Christopher. "Heart of Darkness : Rugby and Racism." Press, 27 July 1999, A5.

Talks to the co-founder of Halt All Racist Tours (HART) and author of the new book 'Dancing on our bones, New Zealand, South Africa, rugby and racism' Trevor Richards. He discusses his time in HART and his role in confronting racist rugby.

\section{M65}

Mourie, Graham \& Ron Palenski. Graham Mourie Captain. Auckland: Moa Publications, 1982.

Autobiography of 1976-1982 All Black Graham Mourie, considered as one of New Zealand's finest captains and open-side flankers. He explains his decision to abstain from playing South Africa and the reaction it provoked within rugby circles. He also gives a background of the history of debate over Maori inclusion to tour South Africa and dissects arguments used by those who supported contact with South Africa.

N1

Nauright, John. "Myth and Reality : Reflections on Rugby and New Zealand Historiography."

Sporting Traditions 6, no. 2 (1990): 219-30.

This paper examines recent writing on the history of rugby in the context of New Zealand's social history and suggests areas for future research and theoretical formulations. 
N2

Nauright, John. "Sport, Manhood and Empire: British Responses to the New Zealand Rugby Tour of 1905." Sporting Traditions 8, no. 1 (1991): 239-53.

The success of the All Blacks in 1905 was cause for significant debate in Britain. While in New Zealand it proved to be an integral ingredient in the establishment of a "national ethos" in Britain it reinforced assumptions on the decline of manhood in Edwardian Britain and social commentators asked "why did the All Blacks triumph?" The style of the New Zealanders play and 2-3-2 scrum influenced a number of British clubs to change and mimic the New Zealanders. The article investigates early British responses to the tour and perceptions of the state of British manhood compared to the virility of the New Zealanders and the economic impact of the All Blacks success.

N3

Nauright, John. " 'Like Fleas on a Dog': Emerging National and International Conflict over New Zealand Rugby Ties with South Africa: 1965-74." Sporting Traditions 10, no. 1 (1993): 54-77.

An assessment of the relative impact of sporting sanctions on white South Africa with regards to rugby, the dominant sport of the elite white males. This article argues that a historical understanding of the links between South Africa and New Zealand in international rugby is essential to analyse the effects of sporting sanctions on the target group of whites in South Africa. It was during the period from the mid 1960s to the cancellation of the 1973 rugby tour of South Africa to New Zealand that the issue of New Zealand - South African rugby became central in both the apartheid state's international sport strategy and in the boycott movement's attempts to isolate South Africa in sport. The Olympic movement was not the most crucial event in the attempt to isolate South Africa in sport but rather the campaigns to eliminate South A frica from international rugby were more significant when assessed in terms of influencing white South A fricans. The influence of rugby and the construction of 'national identity' in both South Africa and New Zealand are examined. In New Zealand a defeat reflects unfavourably on the quality of New Zealand manhood and its way of life. The attitudes of the major political parties in New Zealand towards South Africa and the boycott issue are explained. National's policy was that there should be no interference with the right of New Zealand sports people to participate with whomever they pleased.

The Verwoerd statement in 1965 that all future teams touring South Africa would have to abide by South Africa's 'local custom' meant no Maoris would be welcome to tour. This led to the postponement of the proposed 1967 tour to South Africa. South African president Vorster's decision to allow Maoris into South Africa as members of All Blacks in 1970 contributed to a split in the National Party of South Africa (NP) and the secret Afrikaner male elite organisation the Broederbond. This was the first major concession 
made by the South African state which allowed them to resume regular sporting contact. The origins of Halt All Racist Tours (HART) and Citizens Association for Racial Equality (CARE) are explained and why they continued to intensify the campaign against South Africa, part of the motivation being the NZRFU's repeated refusal to meet with those who opposed rugby contacts with South Africa. The media is examined in how they portrayed the South African issue and how Maori groups were also divided. Nauright explains the political machinations with the proposed 1973 South African tour to New Zealand potentially causing a boycott of the Christchurch Commonwealth Games of 1974 and how Norman Kirk dealt with the issue eventually leading to the cancellation of the tour.

\section{N4}

Nauright, John. "Race, Rugby and Politics: New Zealand and South Africa 1921-1992." Journal of Physical Education New Zealand 26, no. 3 (1993): 19-22.

An overview of the interaction of rugby, race and politics between South Africa and New Zealand since tours between the two countries began in 1921. Nauright considers the role of the New Zealand Rugby Football Union (NZRFU) in sporting contact with South Africa and the influence of the Citizen's All Black Tour Association (CABTA), the Citizen's Association for Racial Equality (CARE) and Halt All Racist Tours (HART). Analyses the 1981 Springbok tour and the role of the NZRFU and New Zealand National Party.

\section{N5}

Nauright, John. "Colonial Manhood and Imperial Race Virility : British Responses to Post Boer War Colonial Rugby Tours." In Making Men : Rugby and Masculine Identity, edited by John and Timothy Chandler Nauright, 121-39. London: Frank Cass, 1996.

With social commentators in the start of the 20th century asserted that the best determinants of physical condition during peacetime were sporting contests. Poor performance in the Boer War coupled with a series of sporting defeats at the hands of New Zealand and South Africa confirmed widely held suspicions that the British nation faced a serious crisis. Article looks at the theory of physical deterioration and the effect of the 1905 All Blacks on the British consciousness. 
N6

Nauright, John. "Sustaining Masculine Hegemony : Rugby and the Nostalgia of Masculinity." In Making Men : Rugby and Masculine Identity, edited by John and Timothy Chandler Nauright, 22744. London: Frank Cass \& Co Ltd, 1996.

Nauright puts forward the idea that specific links between rugby and what it means to 'be a man' are not fixed and attempts to explore some of the recent aspects of the role of rugby in contemporary societies in New Zealand and South Africa. Looks at the role of nostalgia to sustain nationalism. In New Zealand he opines that nostalgic representations of rugby attempt to take people back to the days before the violence surrounding the 1981 Springbok tour of New Zealand. He highlights what he considers as threats to the national game such as greater choice of options for youth, the rise of soccer, the detrimental effect of rugby violence and the changing demographics and suggests a shifting view of rugby in a changing social environment.

N7

Nauright, John and David Black. "'Hitting Them Where It Hurts' : Springbok - All Black Rugby, Maculine National Identity and Counter - Hegemonic Struggle, 1959-1992." In Making Men : Rugby and Masculine Identity, edited by John and Timothy Chandler Nauright, 205- 26. London: Frank Cass \& Co Ltd, 1996.

Explores the links between politics, sport and struggles over hegemonic masculinity in New Zealand and South Africa during a period when the issue of sporting boycotts developed. Examines contrasting attitude of race relations in New Zealand and South Africa, and looks at actions of successive governments in respect to contact with South Africa. Nauright comments on the growing disquiet, protest and social change in New Zealand.

N8

Nepia, George \& Terry McLean. I, George Nepia. London: London League, 2002.

Autobiography of George Nepia, famous All Black fullback who played every match on the 1924 Invincibles tour. The original edition of I, George Nepia was published in 1963, New Zealand by AH \& AW Reed Ltd and in Great Britain by Herbert Jenkin Ltd with the title: I, George Nepia - The Golden Years of Rugby. 
He backgrounds his life growing up in the East Coast and details the style and flair of Maori players. The book follows his exploits in Britain and in the chapter "Apartheid in sport" Nepia gives his own thoughts on the South African issue and the New Zealand Rugby Union deciding that it would be impolitic for the noncaucasians to travel to South Africa. Nepia and another Maori player Jimmy Mill did not cry themselves to sleep over the decision but Maori disliked the racist treatment towards millions of non whites in South Africa and were saddened and humiliated by the attitude of the New Zealand Rugby Union. Nepia tackles the controversial 2-3-2 scrum which the 1930 British Lions manager James Baxter called cheating but which Nepia believes encouraged speed in play. Nepia gives the reasons for defecting to league and the reactions from rugby people. The extra material includes a retrospective look at the Invincibles place in history and the society the Invincibles represented and how rugby influenced this society.

01

Ogilvie, David. "Great Memories for Meads." The Evening Post, 24 July 1998, 14.

Meads recalls his playing days against the Springboks whom he considers the ultimate opponent, and his role in the rebel Cavaliers that toured South Africa in 1986 and led to the members being stood down for two matches.

$\mathrm{O} 2$

Ogilvie, David. "Rebel All Blacks Raked in Cash, Says Fraser." Evening Post, 16 August 1999, 1.

Bernie Fraser confirmed that the rebel Cavaliers received payments but Murray Mexted said the figure of $\$ 50,000$ was wrong and counters with the claim that Haden is only seeking publicity.

O3

O'Hagen, Sean. The Pride of the Southern Rebels. Dunedin: Pilgrims South Press Ltd, 1981.

This book tells the story of the development and evolution of rugby in relation to Otago. Anecdotes of the macho values and attitudes are illustrated. At a function after the first Otago - Canterbury game in $1878 \mathrm{Mr}$ Dixon of the Dunedin club asked the assembled footballers "Was it to be held for a moment that on account of its danger football should be given up and young men should grow up effeminate?" Loud cries of "No, no" and "Never" rose from his audience. "There was not the slightest doubt" he continued "that football improved the stamina of Englishmen, Scotsmen and Irishmen". 
Details the exploits and controversies of father and son Otago coaches Vic Cavanagh Senior and Junior. Early professionalism in the dawn of the 20th century raised alarms of the amateur ethos being threatened. The politics of the wing forward position is explained.

04

O'Meagher, Steven. Fronting Up: The Sean Fitzpatrick Story. Auckland: Moa Beckett, 1994.

Biography of All Black hooker and captain Sean Fitzpatrick. He reveals the internal politics and player relations that hindered the All Blacks attempt to defend their World Cup title in 1991. Particular attention is given to player power inside Auckland and the All Blacks which destroyed team ethos. Fitzpatrick recalls the reaction to the violent 1992 New Zealand v New South Wales match and the furore that broke over Richard Loe who smashed Paul Carozza's nose and follows the events of the end of South African isolation and the team meeting Danie Craven who gave a controversial speech on New Zealand South A frican rugby relationship. Fitzpatrick gives witness to the Cavaliers - David Kirk tension. The philosophy of being a hard man driven by a sense of ultra competiveness is explored where Fitzpatrick gives examples and attitude to physical and mental intimidation and passes the judgement that the French are dirtier than any other team. The public expectations of the All Blacks and their reaction to defeat is explored and the strained relationship with the media is touched upon. This theme is expanded to include the animosity between the British press and the All Blacks during their tour of England and Scotland in 1993 including the Phil de Glanville stomping at Redruth and arguments over the validity of the ruck while also touching upon accusations of racially abusing English prop Victor Ubogu.

\section{5}

Orsman, H W. "All Black Talk." Comment : a New Zealand Quarterly Review, no. 41 (1970): 6-7.

Orsman questions the wisdom of sending a rugby team to tour in South Africa in 1970 in a growing climate of the awareness of racial equality. Continued sporting relations with the Republic will tarnish New Zealand's reputation. 
P1

Palenski, Ron. Our National Game. Auckland: Hodder Moa Beckett, 1992.

Palenski looks at the effect of rugby on New Zealand society and details the background of how and why rugby flourished in New Zealand and became the national game. He looks at the issues of developing masculinity, how rugby helped race relations in New Zealand and provided a focal point for nationalism. He chronicles the history of the great tours and the style of the All Blacks and the tactics that have sometimes put New Zealand under severe criticisms from their Northern Hemisphere opponents in particular. The dilemma of amateurism versus professionalism is examined and the ethics believed to be associated with each. Included are details of Andy Haden's battles with the establishment over charges of professionalism and league poaching and David Lords attempted rugby circus. The relationship with the press is looked at and the often difficult relationship with South Africa is explored in depth including the Cavaliers episode. The development of the World Cup and ever growing momentum towards greater commercialism is considered.

P2

Palenski, Ron. The Jersey. Auckland: Hodder Moa Beckett, 2001.

Book examines the meaning of the All Black jersey as a symbol of the All Blacks and the part it has played over 100 years in shaping New Zealand's psyche. It explores the notion of sacrifice and struggle, including episodes of violence to achieve success and the mythological aura that has surrounded the jersey. Palenski supplies a comprehensive statistical summary of every All Black up until the end of 2000 .

P3

Palenski, Ron. Century in Black. Auckland: Hodder Moa Beckett, 2003

Essentially a rugby history but also has elements of a social history of how rugby has influenced New Zealand society and vice versa. The rivalry between all of New Zealand's traditional foes are all detailed. It concentrates on the incidents that have fired nationalistic sympathies between rugby nations. Palenski offers the latest version of why Keith Murdoch was sent home from Britain in 1972 and gives 
further insight as to why New Zealand has special relish in wishing to defeat England. The sending off of Maurice Brownlie and Colin Meads are revisited with a section devoted to explaining the rationale of the rugby enforcer.

The relationship with apartheid South Africa is described as "dreadnoughts of rugby, lobbing massive salvos at one another while the other countries were the cruisers to be picked off at will” (p191). The origins and history of the World Cup and the entry into professionalism are all covered. This celebration of rugby provides anecdotes of all the tours and major tests to bring to the reader the stoicism, brutality and national fervour that accompany these encounters.

P4

Panckhurst, Paul. "Scragged, Beaten and Bitter." Unlimited, (June 2002): 36-43.

Investigates how and why the New Zealand Rugby Football Union (NZRFU) lost the rights to sub-host the 2003 Rugby World Cup.

P5

Parahi, Carmen. "Surviving the Press and Myself ..." Tu mai, no. 27 (2001): 18-19.

Focuses on the Norm Hewitts' life and experiences with violence, as outlined in 'Gladiator: the Norm Hewitt story' by Michael Laws.

P6

Park, Julie. "the Worst Hassle Is You Can't Play Rugby": Haemophilia and Masculinity in New

Zealand." Current Anthropology 41, no. 3 (2000): 443-53.

Park examines the place of rugby as an idiom of distress or normality in the lives of men with hemophilia and as a symbol for and a practice of a hegemonic form of masculinity in New Zealand. She argues that this historically produced gender order creates particular difficulties for some men with hemophilia in several areas of life. 
Parker, Selwyn. "Leadership with Hart." Management 44, no. 1 (1997): 34-44.

John Hart, coach of the All Blacks is described as having a management style that has transformed a team of amateurs into an unbeatable professional combination both on and off the field. According to Hart, the key to the success of the All Blacks in 1996 was planning and preparation. Hart empowered his team; rather than inhibiting his players, his goal was to unleash their experience and talents by giving them creative freedom. Hart's 15 steps to a winning edge are listed. 
Phillips, Jock. "The Hard Man: Rugby and the Formation of Male Identity in New Zealand." In Making Men: Rugby and Masculine Identity, edited by John and Timothy Chandler Nauright, 70-90. London: Frank Cass, 1996.

Describes manliness tempered by civilising restraints. The identity of Pakeha males forged by interaction of two powerful traditions: a desire to preserve the muscular virtues of the frontier against feared urban decadence, and the concern to discipline that masculine spirit and contain it within respectable boundaries. The purest expression of the stereotype has been found in rugby football. Backgrounds how the game was introduced to New Zealand and how it spread quickly through the dominion and became established as the 'national game' of New Zealand. Though the game began as elitist, it quickly became the sport for all classes. Rugby allowed colonial men a physical expression of mateship without suspicion of deviancy. From the beginning it was associated with drinking in the pub and regarded with some ambivalence by middle classes, judging rugby as a "rough and dangerous game" and "was only worthy of savages".

Organization of provincial unions helped standardised the rules. Positions developed and style saw it become less violent and more scientific. The civilising process continued with the establishment of the NZRFU in 1892. By the turn of century rugby is seen as a manly exercise and compulsory training for the civilised gentleman and to keep the British race rural and pure. Rugby taught the principle that individuals must work for the greater good of the team, and it developed character.

The impact of the 1905 "Original" All Blacks that toured the UK and France, led New Zealanders to view rugby success as the very essence of New Zealand identity. Opinion makers in England made much of the team's achievements and interpreted the All Blacks in a way which gave special meaning to New Zealand.

Q1

Quaintance, Lauren. "Rugby Thugs Wary of the Courts' Penalties." New Zealand Herald, 27 Apr 1996, section 1, 7 .

Considers whether police should get involved with violence on the sports field. Ian Jones was cleared of assault on Junior Paramore in an NPC match in 1995. Paul Davison, his lawyer says court action should be reserved for particularly brutal on field assaults. The NZRFU CEO David Moffet said that while the Union supported prosecution for vicious assaults it would not call the Police. 
Q2

Quinn, Keith. Lions 77. Wellington: Methuen New Zealand Ltd, 1977.

Details the flow and consequences of every match of the tour, provides all the necessary scoring references and statistics and evaluates the qualities of the Lions as a playing unit, as tacticians and as individuals, on and off the field. Gives details of the Lions frustrations touring New Zealand and the acrimony shown by local crowds towards the Lions.

Q3

Quinn, Keith. Tour of the Century: The All Blacks in Wales 1980. Auckland: Methuen New Zealand, 1981.

Quinn looks back at the rivalry of Wales and New Zealand climaxing with the 1980 centenary test including the confrontations, violent controversies and dramas of the 1970's. Starting with the 1980 All Blacks tour to Australia, Quinn attributes the lack of international leadership in the management and uninspired coaching from Eric Watson with the unavailability of Mourie to the reason of failure, Australia winning the series 2-1. Mourie's return for the Welsh tour forged team unity, identified, exemplified and emphasised the significance of the tour. The tour was adjudged a great success restoring the true reputation of the New Zealand public after the bitterness and acrimony of previous years.

Q4

Quinn, Keith. "Rough at the Top." Rugby World; 1995, January 1995: p65, 4p.

Violence involving some of New Zealand's top rugby players has overshadowed the playing highlights of the 1994 season. This has resulted in the suspension of some key players, rough-play incidents and the attempts of New Zealand Union to clean up the game. The role of referees in controlling violence is examined. 
Q5

Quinn, Keith. "Relief and Regret." Rugby World, October 1995: 66-68.

Focuses on the effect of the opening of New Zealand rugby football to professionalism. Article focuses on New Zealand's teams' support for the professionalism of the sport and the policies of the New Zealand Rugby Union (NZRU) regarding the payment of its players. Quinn pinpoints the increase in the number of players who want to link with the NZRU and the issues involved in the payment of players under the NZRU.

\section{Q6}

Quinn, Keith. Legends of the All Blacks. Auckland: Hodder Moa Beckett, 1999

Quinn presents a book that celebrates the exploits of New Zealand rugby players that have added to the legend of the All Blacks. Explores in detail the enduring rivalry with South Africa including the notorious match between the Maori and the 1921 Springboks. Violence was seen as a central theme that characterised All Black - Springbok clashes and Quinn focuses on the attempt to use thuggery to eliminate All Black prop Kevin Skinner in 1956. The development of the protest movement in New Zealand is profiled.

Included is a section on captains involved in All Black matches, those who led New Zealand and those who led the opposition and contains a section on the Wayne "Buck" Shelford controversy.

Quinn provides a section on the All Black coaches and breaks down the eras of each coach. There is reflection on the rivalry with Australia and their emergence as a super power and Quinn examines the issue of professional rugby and makes comparisons with the amateur ethos and reality.

The key points of observation from players who made playing for or against New Zealand so special are detailed. Quinn also investigates the claims of food poisoning in South Africa during the 1995 World Cup. Included are transcripts of interviews from players and historians on a range of subjects including the Meads sending off in 1967, the Mafia men of the 1972-73 tour to the UK and the Keith Murdoch incident. Also contains player perspectives of the World Cup and the Hart-Wylie co-coach breakdown of 1991. 
Q7

Quinn, Keith. Outrageous Rugby Moments. Auckland: Hodder Moa Beckett, 2002.

Quinn examines many of the great controversies of New Zealand rugby and offers his own version on a number of these incidents often from the perspective of a reporter or as someone more personally involved.

Included how Richard Loe, seen by many as a thug, progressed from rugby's bad boy to a pillar of the establishment. Other issues explored are: the John Hart debate, Louis Luyt's 1995 World Cup speech, the food poisoning debacle, the "Bring Back Buck" phenomenon, the Colin Meads sending off, Jaap Bekker kicking 'Tiny' White in the spine during the 1956 tour, Questionable refereeing in Springbok - All Black rivalry, the telegram of shame- South African racism in New Zealand 1921, the Battle of the Bridge- the violent 1994 NPC final between Auckland and North Harbour, the violent Canterbury v Lions match 1971, Keith Murdoch being sent home 1972, the "No Maoris No tour" debate, Johan Le Roux ear biting incident of 1994, Mourie abstaining from playing the 1981 Springboks, the booze that brought banishment for Ron Rangi, Mike Gilbert being excluded from rugby union circles for playing league, the player -coach drain to overseas, what happened when rugby became professional, when Joe Stanley and Andy Earl were jailed in Wales, early professional rugby in 1907, Cyril Brownlie being the first man sent off in international rugby, the 1986 rebel Cavaliers tour of South Africa, the John Ashworth and Graeme Higginson stomping affairs in Wales in 1978 and 1980.

R1

Raea, Steve. "The Player Trade." New Zealand Herald, 3 August 1996,7/1.

Investigates the impact of professionalism on school rugby teams. Looks at the situation of $1 \mathrm{st} X \mathrm{~V}$ players in several Auckland state and private secondary schools and how it has changed the nature of schoolboy rugby.

\section{R2}

Rattue, Chris. "Mitchell's Long and Winding Road." New Zealand Herald, 17 November 2003, A1820.

Conducts a post mortem on the All Blacks' failure to win the 2003 Rugby World Cup with emphasis on the methods of coach John Mitchell. 
R3

Redman, Christopher. "Mud, Sweat and Cheers." Time International (New Zealand edition) 138, no. 15 (1991): 52-57.

Describes how the rugby establishment hopes to capitalise on the 1991 Rugby World Cup by promoting the sport internationally. Past players comment on the social benefits of playing rugby and the likelihood of the game becoming professional. Looks at the history of the game and briefly profiles fifteen current internationals who were expected to make an impact.

R4

Rees, Paul. "Just Pugh Do You Think You Are?" Player, (May 2002): 40-45.

International Rugby Board chairman Vernon Pugh is interviewed about the fiasco surrounding the stripping of New Zealand's sub-host status for the 2003 World Cup.

R5

Reid, Brett. "Scrumming on Empty." New Zealand Sport Monthly, (February 1998): 66.

Explains the effects of overload and physical burn-out on professional rugby players.

R6

Reid, Tony. "Andy Leslie- Just an Ordinary Clark Kent." New Zealand Listener 77, no. 1823 (1974): p 42-43.

Reid profiles the former All Black captain Andy Leslie: his Petone background, his appreciation of loyalty and sacrifice and gathers his opinions on what he sees as the uncertain environment that New Zealand rugby finds itself in. Leslie reflects on attitude and pressures of captaincy and contrasts his times in the 1970s with modern day rugby and the new cult of All Black individualism. He maintains his attitude to playing South Africa as "helping integration" and "bridge building". 
R7

Reid, Tony. "First of a New Breed in Rugby." New Zealand Herald, 16 July 1983, section 2, 1-2.

Andy Haden expounds his controversial views on the game and recounts his clashes with rugby administrators who see him as a maverick. At a time when the rugby authorities were very suspicious of any behaviour that may compromise the sports strict amateurism code he declared himself a professional whose pay cheques have been held up in the mail. He recalls his decision to drop out of New Zealand rugby for a while playing in France and Italy where playing for pay was not uncommon. The spin offs from rugby have offered financial opportunities and gives his opinion on professionalism and the mixing of sport and politics. He refers to Greg McGees play "Foreskins Lament" and his belief that sport will always be an expression of New Zealand nationalism.

R8

Reid, Tony. "John Minto: No Magic Button to Push." New Zealand Listener 110, no. 2366 (22 June 1985): p 20-21, 24.

The chairman and main spokesman for HART believes the Rugby Union will not persist with the South African tour if it means sacrificing rugby itself. He accuses the NZRFU of ignoring every moral question for the last 20 years. Article backgrounds how Minto became the most prominent and controversial figure in the anti-tour movement and examines changes in public attitude since 1981.

Describes the different definitions of New Zealand culture and maintains his belief that "..freedom to play rugby is not as important as opposition to a political system that denies black people decency". He gives his views on the violence of anti-tour demonstrators in 1981 which he believes had been greatly exaggerated. He discusses how the media portrayed their demonstrations and himself and how he handles threats from pro-tour supporters.

R9

Revington, Mark. "Brother of Mercy." New Zealand Listener 180, no. 3201 (15 September 2001): 2930 .

Reports on the return of Laurie Mains as coach of the Otago rugby team after his stint coaching in South Africa. Looks at his career highlights and achievements while discussing Otago's performance and 
gives his views on team culture, overpaid players, player maturity and skills. Mains outlines his coaching style and philosophy towards rugby.

\section{R10}

Revington, Mark. "Why Jonah Isnt White." New Zealand Listener Vol. 184, no. Issue 3244 (13 July 2002): 22.

Focuses on the Polynesian dominance in professional rugby in New Zealand and the popularity of Polynesians in professional sports. The excellence of Polynesians in sports is due to their physical build and are earlier to mature compared to non-polynesians. There is an acknowledgement that there is a degree of complacency of the country in identifying and developing sporting talent.

\section{R11}

Reyburn, Wallace. The Unsmiling Giants : The 6th All Blacks Tour. London: Stanely Paul, 1968.

Reyburn laments the style that New Zealand had played throughout the 1950s and 1960s. The forward domination philosophy created world class forwards but neglected the sparkling back play that was typical of the New Zealand style for the first half of the century. Reyburn recalls the tours that made New Zealand rugby top of the world tree and wooing crowds with exciting open running style despite the fact that at times their forward pack as a whole were smaller in comparison to their opposition. He analyses and debates the merits of the scrum formations that the All Blacks employed and what they faced. He argues the merits of the 2-3-2 scrum, and describes the events that led New Zealand to abandon their free flowing style in favour of forward domination. Describes the tour to Britain as the ultimate to All Blacks being "a trip home". He points to the superior training runs that marks the New Zealanders from the British. Reyburn questions the integrity of the haka performed by white players and backgrounds the rugby relationship between coach Fred Allen and manager Charlie Saxrton, both who had served together during World War Two. A whole chapter is devoted to Colin Meads, written before Meads was sent off against Scotland, and another chapter puts the controversial incident under the microscope, implying that Meads was hard done by but defends the referee from being judged on the television replays. Reyburn praises the style of the 1967 All Blacks and hopes that this is a return of a new happy era of free flowing rugby. 


\section{R12}

\section{Reyburn, Wallace. The Winter Men : The Seventh All Blacks Tour: London Hutchinson Publishing Group, 1973.}

Review and reports of the 1972-73 All Black tour of Britain, Ireland and France. Reyburn laments that the young inexperienced All Blacks became the most controversial All Blacks to have ever toured Europe. The style of the All Blacks under coach Bob Duff who was a disciple of ten man rugby frustrated followers of the game but worse was the rank indiscipline of the team that sometimes descended into crassness. He profiles the perceived wild man Keith Murdoch and details the incident that led to Murdoch being sent home in disgrace. Reyburn believes Murdoch should not have been selected in the first place referring to incidents of brawling when he was touring South Africa in 1970. Though Duff was an unimaginative coach it must be said that his obsession with rucking was the basis of the success that his team and their predecessors enjoyed against the British and Irish. Reyburn looks into claims that the British media was involved in a smear campaign against the All Blacks and that the All Blacks were rude and uncooperative to rugby fans and on the field were a dirty team. He believes that the antagonistic attitude presented by the All Blacks reflected the change of attitude of New Zealand towards mother Britain.

\section{R13}

Richards, Huw. "Rugby Union Changing Face in New Zealand Game." Financial Times, Nov 5 1999, 19.

Chris Grinter, chairman of the New Zealand Schools Rugby Union and headmaster of Rotorua Boys High School, points to the national schools squad as a reliable indicator of how the All Blacks will look in a few years time. "We reckon to have spotted most of the top-class talent available, and the arrival of professionalism has meant that where rugby once helped you get a better job, it now provides serious career opportunities for young New Zealanders. We now have youngsters who are seriously focused on a career in rugby and reckon that anyone who makes the schools team has about a one in three chance of becoming an All Black."

Fifteen to twenty years ago, Pacific Islanders were a rarity in the New Zealand schools team. This year there were 16 in a 26-strong squad - 11 Samoans and five Tongans - alongside four Maoris and six Pakeha. While movement between New Zealand and the islands makes nationality issues rather complex - there are more Samoans in Auckland than there are in Samoa - Grinter notes that "all but one of the squad has a New Zealand passport". Historian Jamie Belich compares their success to that of Afro-Caribbean footballers in Britain and suggests it has raised the status of Pacific Islanders in New Zealand. 


\section{R14}

Richards, Trevor. "The All Black Tour and Its Non Achievements." New Zealand Monthly Review 12, no. 125 (1971): p 16-18.

Richards looks at what the 1970 All Black tour to South Africa achieved after its followers proclaimed that "the tour will light a torch for humanity". The argument that South African administrators and politicians would be impressed by the All Blacks display of multi-racialism had been proved naive. Richards argues that rather than hastening progress, the 1970 tour was a retrograde step with examples of non-whites attacked by whites after matches in South Africa and South African President Vorster categorically repeated that his government would not countenance multi-racial sport in South Africa and rather than relax racial policies in sport Vorster entrenches apartheid in sport. Richards notes rugby reporter Terry McLean going on record saying that the tour achieved absolutely nothing and he could not support the visit of the Springboks to New Zealand in 1973. Richards accused New Zealand sporting bodies as being ignorant, irresponsible and evasive in as far as relations with South Africa are concerned. Racist South African sport bodies faces with world public opinion were allowed to make a last ditch stand due to support given by New Zealand sports bodies. The Halt All Racist Tours (HART) became frustrated by lack of correspondence with sports bodies and government and offered the thought that only a commitment to a less tolerant and more controversial militancy of thought and action can produce a situation where either the Government or the sporting bodies concerned are prepared to call off sporting contacts, an obvious weapon being militant non-violent disruption, which was a successful tactic used by demonstrators during the Springbok tour of Britain and Ireland in 1969-70.

\section{R15}

Richards, Trevor. "Events That Cut to the Heart of a Nation." Evening Post, 23 Jul 1996 1996, 7.

Traces the sporting contact between the South African Springboks and the New Zealand All Blacks during the time when apartheid dominated the South African scene. Richards examines the issues involved and the significant sociological impact on New Zealand rugby which removed the sport from being the undisputed sport of choice for New Zealanders. 


\section{R16}

Richards, Trevor. "Thou Shalt Play! What 60 Years of Controversy over New Zealand's Sporting Contacts with South Africa Tell Us About Ourselves." New Zealand Studies 6, no. 2 (1996): 26-32.

Looks behind the confrontations over the 1981 Springbok rugby tour to consider the development of the competing sets of values of the opposing groups, the anti and pro tour factions. Gives a brief history of New Zealand sporting contracts with South Africa from 1902-1992. Focuses on the attitudes of New Zealanders towards sport and race and looks at the role of opportunist politics. Suggests that the conflict also represented a clash between 'old' NZ and the 1960s post World War II, post colonial, international world.

\section{R17}

Richardson, Len. "Rugby, Race and Empire: The 1905 All Black Tour." Historical News, no. 47 (1983): 1-6.

Richardson seeks to understand why New Zealand provided such a congenial environment for an upper class English game. The success of the 1905 team had caused a shock in the British Rugby establishment. Despite criticism of the use of the wing forward, British scribes came to concede the obvious superiority of the colonials on the playing field and some social commentators pointed to the 'soft urban life' sapping the physical strength and moral fibre of the British race. This caused alarm by the 'dwarfing of Europe' - decline in European birth rates compared to those in Africa and Asia. Other commentators saw New Zealand success as evidence that colonial life produced a superior breed of man. New Zealand's Premier Richard Seddon took advantage of football success for political gain emphasised New Zealand's sporting success strengthened the imperial link. Defeat by Wales only added to the teams legend, with Wales victory elevated to the 'pantheon of Welsh achievement' and explanations used fashionable theories of race and blood and the assumed superiority of the Briton.

Rugby in New Zealand was seen as countering the physical decline of youth. Previously rugby had been linked with pub culture and larrikinism, leading schools to counter this by promoting and influencing rugby within their infrastructure to influence what happens in the playground, building character and shaping the nation. Being better than Australia in rugby and proclaiming it as the national game simultaneously proclaimed loyalty to Britain and independence from Australia where cricket had become Australia's national game. The concerns of middle class New Zealand to preserve a British empire was seen as under threat from non-European influences, and rugby was seen as imperative to racial fitness. 


\section{R18}

Richardson, Len. "The Invention of a National Game: The Struggle for Control." History Now Te Pae Tawhito o Te Wa 1, no. 1 (1995): 1-8.

Rugby inculcated 'manliness'. History of rugby's rise to prominence in New Zealand became struggle between those who sought to protect the game from unwelcome change and those concerned to fashion a football world more in tune with what they considered to be antipodean and sporting realities. Other codes of football were popular as well in late 19th century New Zealand. Rugby was part of drive by respectable classes to civilise the 'great unwashed' so social standards would improve. Employers encouraged the game to spread, in particular the railway workshops. Most early urban rugby players were urban skilled workers. Fears of racial degeneration caused by urbanisation and soft ways of the city saw the promotion of scientific systems of physical education and rugby apostles became increasingly influential amongst those who framed the curricula of schools and teachers colleges. Still fears remained that the popularisation of the game would sully the nobler aspects of rugby. Formation of the New Zealand Rugby Union regarded with suspicion by some provincial unions as putting a stranglehold on change and innovation and preserving the game in its pure British form, others as a North Island mouth piece. Development of leagues and competitions viewed with suspicion by those who held dear the amateur ideal. The 1888-89 Natives tour of Britain fuelled suspicions that the team accepted match payments however gambling was seen as a greater evil.

Tom Ellison argues that a distinction be made between inter-provincial matches and overseas tours advocating touring players be given 'over and above hotel and travel disbursements a weekly sum equal to but no more than his salary or wage at work at home' . Disenchantment over touring allowances fed rumours of a professional team touring Britain. Dissatisfaction with parent ruling body in England, the Rugby Union, saw a suggested series of changes. Some were acted upon by the NZRFU to quicken the pace of the game. World War One helped entrench amateurism with rugby claiming a special role in winning the war. The notion of disciplines and co-operative endeavour and the links between sporting deeds and war are explored. War elevated schools rugby to more prominent place in the sporting calendar, as the sport became the pinnacle of physical sporting excellence.

\section{R19}

Roger, Warwick. Old Heroes. Auckland: Hodder \& Stoughton, 1991.

Roger sets out to discover what it was that made the1956 Springbok tour so special for himself, and for the country. Through his own recollections of the 1956 Springbok tour and those of his contemporaries, older fans, sports commentators and the "old heroes" - players from both sides - he 
compiles a vivid profile of a unique time in New Zealand's social history. It was a time when rugby was the chief diversion and New Zealand displayed its national cohesion nowhere more clearly than in its determination to beat the Springboks.

After 1956 nothing was ever to be the same again. The world was becoming a "global village", more informed, diverse in its opinions, more anxious, less certain.

\section{R20}

Roger, Warwick. "The Polynesian Factor in Auckland Rugby." Evening Post, 13 October 1997, A4.

Roger looks at a Ranfurly Shield game and comments that style of rugby that the Polynesians bring to the game is linked to their physical characteristics.

\section{R21}

Romanos, Joseph. "Shady Deal." New Zealand Listener 161, no. 2999 (25 October 1997): 54

Discusses the confessions made by David Kirk about the 1986 Cavaliers rugby tour of South Africa in his autobiographical book 'Black and Blue' (see K5). Kirk gives his opinion about the manner the other players treated him for his refusal to join the team.

R22

Romanos, Joseph. "The End of Tradition." New Zealand Listener (4 May 2002): 22-24.

Recognises the commercialisation of rugby and criticises the arrogance and naivety of the New Zealand Rugby Union (NZRFU) for failing to wake up to the absence of tradition from today's sport, as evidenced by its mishandling of the 2003 World Cup sub-hosting fiasco. 


\section{R23}

Romanos, Joseph. The Judas Game - the Betrayal of NZ Rugby. Wellington: Darius Press, 2002.

Romanos writes of the game taken over by money and avarice, of its betrayal by greedy players, demanding sponsors and incompetent administrators. He argues that rugby has been reduced to just another form of entertainment. The traditions, values and camaraderie that once made rugby great have all been betrayed. The game is now in serious trouble, racially divided and dislocated from the average club player and fan. Money has changed rugby, and the corporate world has taken over. Betting on rugby has now become a major business. Romanos investigates of where the crowds have gone and its link to the effects of pay television and describes early commercialism of the All Blacks. The incompetence of the NZRFU in their handling of the World Cup fiasco where they lost the rights to sub host the tournament is revealed and how rugby has lost its focus, being caught between rugby as a sport or a business and the introduction of the spin doctors.

The 'Shamateurism' era that preceded professionalism led to the lack of All Blacks playing for their clubs which leads to a decline in standards. It takes in the NPC from its early days and the impact of professionalism on the NPC and the Ranfurly Shield. Romanos examines how the World Cup has altered the rugby landscape and the case of diminishing tours, once the life blood of rugby which has been replaced by the Adidas Deal, the Super 12 and how it has hurt New Zealand rugby.

The criticisms of the All Blacks as professionals of not being "normal blokes" any more invites the question whether the professional All Blacks should work to recapture an essential element and values of amateur All Blacks. Romanos laments the lost ability of players to think independently. Changing trends in the New Zealand game focuses on the 'Browning' of New Zealand rugby, the rise of the Polynesian power and the phenomenom of white flight and the reaction from administrators. The changing style of the All Blacks and the current obsession with defence is examined.

Part 5 looks at The Greatest Threat to Rugby with chapter 13 examining the schools crisis with playing numbers declining, the threat from soccer and what unions are finally doing about it. Romanos looks to the future and the choices available to administrators of the game. The post-script ends with a positive note with the cleanout of the NZRFU board, seen as the first step on the long road back.

\section{R24}

Romanos, Joseph. "Samoa, So Close." New Zealand Listener 191, no. 3314 (15 November 2003 ): 36.

Asserts the fondness for rugby sports among Polynesians in the small Pacific island of Samoa and marvels at the production of great rugby players from a country so lacking in resources. Praise is given to the performance of the Samoan team in the game against team England during the 2003 World Cup and 
questions on the amount of support given by the International Rugby Board and the New Zealand Rugby Union to the Samoan national team.

\section{R25}

Romanos, Joseph \& Vincent Heeringa. "Into the Black : How Rugby Will Spend Its \$70 Million." Unlimited, (August 1999): 34-44.

Considers how the union is adjusting to the professional era of rugby in terms of balancing its commitment to developing the amateur game and selling the professional product. The union is still trying to get the balance right realising that the professional game will wither if the amateur game is not looked after.

\section{R26}

Romanos, Micheal. "South Africa Tour Clouds Clamp the Champ." Tu Tangata Feb-March, no. 22 (1985): p 12-13

Maori and New Zealand All Black rugby wing Michael Clamp reacts with discomfort when conversation turns to the New Zealand team's 1985 tour to South Africa. He admits the job situation will be tricky if he gets selected. As a government employee there could be an issue in gaining leave.

\section{R27}

Rowe, Stephen \& Brett Whincup. The Full Eighty Minutes: Searching the Soul of New Zealand Rugby. Wellington: Cycoda, 2001.

A kaleidoscope of all aspects of New Zealand rugby, from the internationals and professional Super 12 matches, the grass root games of the second and third division to the school games and club matches. Attempts to capture the soul of New Zealand rugby in all its forms taking in a fans perspective. Former greats gather to reminisce and pay tribute to the All Black legend Don Clarke. 
R28

Russell, Andre. "The New Zealand Rugby Football Union and the 1981 Springbok Tour." Massey University, 1999.

A thesis presented in partial fulfilment of the requirements for the degree of Master of Arts at Massey University. Russell's thesis looks in depth retrospectively into the 1981 Springbok tour. She examines the rugby culture, politics and attitudes of the time that influenced the Rugby Union's decision to invite South Africa to tour. The chapter "Information from the outside" takes in the views and ideology of groups outside the government and the Rugby Union. Chapter 4 takes in the players' attitude to the tour; from those who made themselves unavailable to others who would play the Springboks anytime anywhere. Russell also examines the financial issues of the tour, councillor's attitudes and reactions to the consequences in particular the Chairman Cez Blazey.

R29

Russell, Marcia. "Ron Don, Rights and Rugby." New Zealand Listener 96, no. 2056 (2 June 1979): p 16-17.

Don talks about being sensationally voted off the NZRFU executive committee for making inflammatory statements to press while on a tour of South Africa for a world invitational XV series in 1979. He blames a small group of people who wanted him removed due to pettiness and personal ambition. Article provides details of his background and his interests. Don regards rugby as "the greatest character builder" and comments "there's an increasingly large number of lazy people" and "large percentage of young people today have no interest in sport" seeing it as root causes for New Zealand's social problems. Don adds that "the casual visitor to South Africa doesn't notice apartheid. There are coloured people everywhere mixing freely with the whites".

\section{R30}

Rutherford, David. "Don't Blame the Money." NZ Rugby World, May 2001, 29.

It is too simplistic to blame professionalism for the decline in status, influence and prestige of club rugby. The strategic review the NZRFU is going to implement, will develop broadcasting and marketing strategies to lift the profile of club and school rugby. 


\section{R31}

Rutherford, David. "Up for Grabs." NZ Rugby World, June 2001, 22.

The amendment of gaming laws could lead to the reduction of poker machines which could impact negatively on the ability of rugby clubs to raise funds. Traditional areas of funding such as bar revenue, commercial sponsorship and volunteer fundraising have been eroded hence the reliance on gaming machines.

\section{R32}

Rutherford, David. "Reconsidering the Seasons Structure." NZ Rugby World, July 2001, 22.

There is international consensus that there needs to be a break of at least two months from rugby for players that are playing at the highest level. Providing an international window for tests could lead to rescheduling of the domestic season.

\section{R33}

Rutherford, David. "Beyond 2001: Survival of the Fittest." NZ Rugby World, September 2001, 54-57.

To maintain the stability and sustainability of the international game Rutherford outlines the strategic planning of the NZRFU, where he provides a proposal for a more equitable World Cup, revenue equalisation and new international schedule.

\section{R34}

Ryan, Greg. ""the Originals": The 1888-89 New Zealand Native Football Team in Britain, Australia and New Zealand." University of Canterbury, 1992.

A thesis submitted in partial fulfilment of the requirements for the degree of Master of Arts in History in the University of Canterbury. Ryan uses main themes and incidents of the tour as a basis to examine some aspects of the interaction between race, class, imperialism and sport during the late nineteenth century both within Britain and her colonies. The thesis also explores the diffusion and strength 
of an elite British ethos which linked sport to higher social and political ideals and to the maintenance of imperial objectives.

The first two chapters trace the composition of the team, motives for the tour and initial responses to it in New Zealand. In the context of colonial aspirations the tour was seen as having an important bearing on British perception of the fledgling dominion. Relationships between Maori and European are also discussed. Chapters 3, 4 and 5 look at the dichotomy between elite and working class interests which is revealed in contrasting responses to a predominantly Maori team and to its behaviour on and off the field. The final chapter and Conclusion set to challenge standard interpretations of the native team and consider its wider value as an indicator of new perspectives on the study of sports history.

\section{R35}

Ryan, Greg. "Rugby Football and Society: The "New Zealand Native" Tour of 1888-89." Historical News 1992, October (1992): pp 12-14.

Backgrounds the 1888/89 NZ Native Football team tour of Britain and Australia. Considers the study of rugby and sport generally as a neglected area of New Zealand history.

R36

Ryan, Greg. "Anthropological Football: Maori and the 1937 Springbok Rugby Tour of New Zealand." New Zealand Journal of History 34, no. 1 (2000): 60-79.

The history of Springbok rugby tours of New Zealand in the interwar period is investigated, particularly the extensive protest and public debate before the 1937 visit. Examines how the prevailing racial theories of anthropology contributed to the debate and what the events reveal about the reality of contact and race relations between Maori and Pakeha in the period.

R37

Ryan, Greg. "Rural Myth and Urban Actuality: The Anatomy of All Black and New Zealand Rugby 1884-1938." New Zealand Journal of History 35, no. 1 (2001): 45-69.

Discusses the myth of New Zealand rugby as a predominantly rural and egalitarian sport, established as the 'national game' by the 1880s and part of the pioneer spirit. Article considers the 
haphazard state of rural and provincial rugby clubs in the 19th century. Examines the social origins and occupational profile of the All Blacks of 1884-1938 and finds that in relation to the wider population they were disproportionately urban, educated and employed in professional occupations.

\section{S1}

Salizzo, Ric. "The Enemy Within." New Zealand Sport Monthly, no. 72 (1998): 10.

Salizzo examines the effects of professionalism in rugby football including an examination of the psyche behind rugby, relating to youngsters and how they deal with professionalism in rugby.

S2

Sanders, Dave. "Playing Away for Keeps ... Chequebook Out." New Zealand Sport Monthly, no. 9 (1992): 38-42.

Discusses the increasingly large number of rugby players and coaches going overseas on job contracts and considers the issue of whether New Zealand rugby should turn professional.

S3

Scott, Eion. "Hurdling the Big Divide." New Zealand Leisure Manager, Winter (1998): 4-6.

Article examines the impact of professionalism on netball and rugby union and talks to coaches and administrators while briefly considering the role of television in the present and future of the sports.

S4

Shelford, Wayne. Buck : The Wayne Shelford Story. Auckland: Whitcoulls, 1994.

Autobiography of All Black captain Wayne "Buck"Shelford who never lost a game when he led the All Blacks. Known for his mana and hard man image Shelford looks back at aspects of his career that includes the Cavaliers controversy where Shelford loses his job with the navy, when he decided to tour 
with the rebel Cavaliers to South Africa in 1986. He discusses playing overseas in the UK for Northamptonshire and details his controversial sacking as All Black captain in 1990. He goes over his enforcer role with the All Blacks in particular his celebrated punch that knocked out Welshman Huw Richards after the latter had grabbed Gary Whetton's testacles during the 1987 World cup semi-final.

\section{S5}

Slatter, Gordon. On the Ball : The Centennial Book of NZ Rugby. Christchurch: Whitcombe \& Tombs, 1970.

A comprehensive record of rugby, at every level from secondary schools up to international games. Slatter chronicles the development and growth of the clubs around the country and profiles the champion teams, while reflecting how club rugby was a way of life for New Zealand. Representative rugby and the growth of the provincial unions that led the formation of the NZRFU are documented. Style of play in representative rugby was underfire partly due to the urgent desire to win, an inborn trait of the New Zealand rugby player.

Services rugby, including the "Kiwis" the 2nd New Zealand Expeditionary Force (NZEF), the Somme Cup, the 1919 Army team in South Africa and the Freyberg Cup is covered in depth.

Maori Rugby begins with the formation of the Maori Advisory Board and the New Zealand Native team of 1888. Slatter reports on the 1921 match versus the Springboks and the consequent controversy over the racist telegram and takes a close look at the relationship regarding South Africa and Maori.

Slatter celebrates the history of the Moascar Cup- the "Ranfurly Shield" for schools and describes the place of rugby in school priorities and the role of the coach in school rugby.

Much of the book details our rivalry with New Zealand's major international opponents and some of the incidents that stand out with particular reference to the Cyril Brownlie sending off in 1925 and the Meads sending off in 1967, the Bob Deans "no try" of 1905 and New Zealand forward power. Our relationship with South Africa is chronicled including the Mark Nicholls controversy of 1928, Kevin Skinner and the violence of 1956 and comments on apartheid in sport and the cancellation of the 1967 tour to South Africa. The last chapter looks at where Rugby stands in New Zealand society in 1970 and looks ahead to the 2nd century of rugby in New Zealand. 
Sleivert, Gordon \& Tim Hazledine. "Better Attitudes First Step on Path to Sporting Triumphs ; Freeing Passion Can Deliver Top Results." New Zealand Herald, 15 Nov 1999, A13.

Presents two views on how New Zealand's performance in international sporting events can be improved: the first by Gordon Sleivert, the director of the human performance centre, Otago University School of Physical Education, who contends that New Zealand must reform the administration and funding of sport, and abandon the amateur approach to training and selection; and the second by Tim Hazledine, the Auckland University professor of economics who suggests that the failure of the All Blacks to win the 1999 Rugby World Cup is synonymous with the limitations to the top-down managerial model found in many New Zealand organisations. Successful sporting nations are innovative conservatives. They are committed to long term planning and programming. Simple things are done well and creativity and innovation are encouraged.

S7

Smith, Jo. "All That Glitters": The All Golds and the Advent of Rugby League in Australasia." University of Canterbury, 1998.

A thesis submitted in partial fulfilment of the requirements for the degree of Master of Arts in History in the University of Canterbury. 1895 saw the birth of Rugby League with the formation of the Northern Rugby Football Union, which broke away from the English Rugby Union. Their sporting isolation was ended with a touring team from New Zealand dubbed the "All Golds" who were excommunicated from the rugby Union fraternity. The New Zealand team also visited Australia where conditions were ripe for the rapid success of the game. The factors determining this were related to the working class perspective of many clubs and to dissatisfaction with the way the Rugby Union ran its affairs. In New Zealand by contrast there were fewer overwhelmingly working class clubs and fewer grievances. The "All Golds" tour was an entrepreneurial adventure which attracted the support of more middle class players than working class ones and it did not promote a massive club based revolt against the New Zealand Rugby Union. So the game developed only slowly with newly formed clubs struggling to attract individual players from the traditional game which still retained significant working class support. Rugby league was a working class game but its conquest of the New Zealand working class was far from complete. 
Smith, Tony. "Never Stop Striving, Whatever It Costs." The Press, 14 March 2002, news section, 9.

States in detail the embroilment involving the scrapping of New Zealand's sub-host status for the 2003 World Cup. Smith criticises the fickleness of the International Rugby Board (IRB) and urges the New Zealand Rugby Football Union (NZRFU) to do their utmost in lobbying for a fair hearing. Gives a World Cup timeline of notable events from 1997 through April 2002.

S9

Smith, Tony. "Red-Card Offence." The Press, 27 July 2002, D4.

Discusses and comments on the findings of the Eichelbaum report on how the New Zealand Rugby Football Union (NZRFU) lost the rights to sub host the 2003 World Cup.

\section{S10}

Smith, Tony. "Jock on the Line." The Press, 21 September 2002, D1-2.

Biography of Jock Hobbs, former All Black, Cavalier and NZRFU councillor who the New Zealand rugby community has turned to in order to restore confidence in the sport's administration after the soul-destroying stripping of its sub-host status for the 2003 Rugby World Cup tournament. Hobbs was considered the ideal man as being both respected by board members and players alike and was instrumental in securing the All Blacks loyalty to the NZRFU when rugby turned professional in 1995.

S11

Souster, Mark. "Mummy's Boys Turning Their Backs on Rugby." The Times, 31 October 2001, 5.

Article points out that for the first time soccer is played by greater numbers of youths than rugby and Pakeha kids are scared of the bigger and stronger Polynesians. 
S12

Souster, Mark. "Tuigamala Issues Stark Warning over Future of Samoa." The Times, 10 October 2001, 40 .

Former All Black winger Tuigamala laments that the IRB national eligibility rulings will damage Pacific Island aspirations in being a real rugby force, many of whose talented players head to New Zealand at an early age to chase the All Black dream and the New Zealand dollar.

S13

Star, Lynne. "Telerugby Tele90 : Tell It Rightly." Race Gender Class, no. 9-10 (1989): 127-38.

Features the 1987 Rugby World Cup and explores aspects of racism and masculinity in the presentations of Television New Zealand.

\section{S14}

Star, Lynne. "The Language of Televised Sport: World Cup Rugby - a Case Study." University of Auckland, 1994.

Thesis submitted to University of Auckland in partial fulfilment of the requirements for a Phd in Film and Television Studies. The starting point of the thesis is the relationship between rugby and television in New Zealand. In the 1980s both had strong reasons for redefining their partnership in the wake of the 1981 Springbok tour (which damaged the public image of rugby) and in response to the increasing commercialism and competitiveness of the media marketplace. The coverage of the 1987 World Cup by Television New Zealand illustrates the development of 'New image' rugby and new forms of television packaging and presentation. The thesis proceeds to place these changes in a broader historical and theoretical perspective. It examines the relationship between rugby culture and male culture generally, including the ways in which masculinity is developed via male team sports.

The thesis proceeds from stories and pictures of rugby insiders, which indicate the richness and (until the 1980s) the centrality of rugby culture in New Zealand and attempts to combine both 'inside' and 'outside' views of rugby culture. Having grown up within this culture the writer feels that discussions of rugby are limited by their tendency to be strongly 'for' or 'against' with few attempts to acknowledge the opposite position. 
Star, Lynne. "Televised Rugby and Male Violence." New Zealand Journal of Media Studies 1, no. 1 (1994): 33-45.

Examines the portrayal of the masculinity of violence in rugby. Uses the incidence of homophobia in rugby commentary to illustrate the affiliation between 'real men', violence and rugby. Describes how a 'code' of rugby language is used to refer to violence and violent players. The article considers a parallel strand of gentlemanly fair play in rugby discourse. It also looks at the marketing of the 'new man' in rugby, and the contrasting of this with identified violent opponents.

\section{S16}

Stratford, Trish. "Sport : Goodbye Cold Pie." New Zealand Listener 124, no. 2578 (5 August 1989): 44-45.

Looks at the work of Ken Bishop, administration officer for rugby football in Auckland and comments on the commercialisation and promotion of rugby.

\section{T1}

Taonui, Rawiri. "Vitriolic Rugby Fans Need to Learn That You Can't Win 'Em All." New Zealand Herald, 11 November 1999, A17.

Comments on the failure of the All Blacks rugby team to win the 1999 Rugby World Cup. The reaction to All Black losses owes more to the extraordinary expectations placed on them by the public. All Blacks lacked presence and maturity in key areas rather than lacking guts and commitment. Professional rugby meant players were prolonging their careers to bolster their financial positions, an option they did not have in the amateur era. 
T2

Tasker, Norman. "World Cup Fever." Bulletin with Newsweek; 116, no. 5967 (1995): 93-94.

Tasker analyses the preparedness of the Australian rugby teams to compete in the World Cup to be held in South Africa and includes views of the International Rugby Board on New Zealand and Australia's professionalism in rugby and David Lord's game plan to develop rugby.

T3

Tauroa, Hiwi. "Maori Rugby Side "Lawful and Not Discrimatory"." New Zealand Herald, 15 July 1982, section 1, 20.

Against a background of the confrontations arising from the 1981 Springbok tour, the Race Relations Conciliator and former Counties coach argues that one must look within the context of the reasons for the foundation of a New Zealand Maori team. Tauroa argues that Maori teams were playing internationals before formation of the NZRFU in 1892.

T4

Templeton, Malcolm. Human Rights and Sporting Contacts. New Zealand Attitudes to Race Relations in South Africa 1921-94. Auckland: Auckland University Press, 1998.

Templeton draws extensively on the archives of the Ministry of Foreign Affairs and Trade, on contemporary media reports and other public sources, providing accounts of the development of New Zealand attitudes to South Africa, particularly the issue of sporting contact. It contains record of the positions taken by successive New Zealand governments as international pressure intensified for economic sanctions and sports boycotts against South Africa and the shifts in public opinion on what had become by 1981 one of the most bitter controversies New Zealand has known.

The author gives analysis of the complex tensions between the Rugby Union and its supporters, the politicians, the civil servants, the anti apartheid protest movement and the general public. 
Thomas, Clem. "A Collective Fanaticism." New Zealand Listener 86, no. 1963 (1977): p 24.

Thomas provides criticism of New Zealand rugby, its style and attitude. The New Zealand game is referred to as schizophrenic, too concerned with the physical and no regard for skills. Reminds reader that rugby is an amateur sport, and the rugby climate must change or risk the destruction of the great game.

T6

Thomas, Clem. "Fudging the Issue." Rugby World (April 1995): 64.

Looks at the outcome of the International Rugby Board's March 12, 1995 meeting that focused on the issue of amateurism in rugby football. Highlights of a report by the Amateurism Working Party which the Board has published and given to the press and looks at basic problems facing the rugby football game world-wide. Includes announcement of IRB's deliberations on amateurism in August 1995.

T7

Thomas, J. B. G. (John Brinley George). The Avenging All Blacks: The Story of the All Blacks' Tour of the British Isles, 1972-73. London: Pelham, 1973.

The 7th All Blacks will not be remembered in the same way as their predecessors, despite the controversy and criticism that surrounded their tour. They did not win the hearts of the followers of the game in the British Isles, or project the image of New Zealand at a time when it was most needed. They were over-introvert instead of extrovert, in a world of publicity and ballyhoo; they never seemed to bother about their public image, preferring to display a mild form of arrogance both on and off the field. There developed a love-hate relationship with the crowds. At times, the side was criticised more strongly and booed more loudly than any previous touring side.

Thomas surmised that Manager Ernie Todd and All Black coach Bob Duff were too pleasant and too lenient with their side that desperately lacked the discipline particularly where senior players were concerned. It is not easy to measure the loss of prestige suffered by New Zealand rugby in the British Isles through the 'acting up' and apparent arrogance of several players in particular the senior players exerted too much of a negative influence.

The 1972-73 team compares poorly with previous touring New Zealand teams. The author questions whether attitudes are changing in New Zealand and young men are not interested any longer in a love of the 
Mother Country. Thomas looks at reasons for this dramatic change in attitude and relationships and feels the loss of successive tour series to the Springboks and the Lions were almost a death blow to the pride and prestige of New Zealand rugby and disturbed everyone within the country.

Thomas takes issue with McLean's tongue in cheek assertions that the British have taken rugby preparation too seriously. New Zealand success was seen in cynical terms as exceeding amateurism yet when the British copied the methods they were not accused of "being above amateurism". Thomas explores the breakdown in relations with the UK media and the All Blacks.

In chapter 7 "Dial M for Murdoch" Thomas maintains that the All Blacks looked a mere shadow of great All Black teams of previous tours and Wales missed a great chance of victory as the author thought they were the better rugby side. The aftermath of the Murdoch incident is given extra attention. Other examples of bad behaviour from the All Blacks are described. The author gives the All Blacks praise for the way they played the barbarians match, lamenting that they did not play this way earlier.

\section{T8}

Thomas, J. B. G. (John Brinley George). Trial of Strength : The 1977 British Lions in New Zealand. London: Pelham, 1977.

In his preface Thomas writes "The 1977 Lions will be remembered as the unlucky Lions. Throughout it was a dramatic trial of strength, lost in the end through a single defensive error, and played in the wettest winter experienced in New Zealand for many years."

Thomas contends that they could have won the series, instead the memories of the failures and the errors that caused it after the forward struggle had been won, will remain to haunt the Lions of 1977. Poor decision making and insular perspective doomed the Lions to fall short of promised potential.

Thomas explores the commercial benefits of the tour to New Zealand and how the Lions felt exploited. Book contains a plea for shorter tours and also directs criticism towards New Zealand referees and the hostile attitude of sections of the crowd at matches and of local opponents who Thomas regarded as violent perpetrators and apportions some blame on the advent of sponsorship.

He gives a warning to the Welsh centenary in 1980 fearing that it could end up in a bloodbath with antagonisms reaching unprecedented levels. 
T9

Thomas, Paul. Kirwan- Running on Instinct. Auckland: Moa Beckett, 1992.

Biography of All Black winger John Kirwan, who was picked as an 18 year old by coach John Hart to represent Auckland and became one of the players that dominated the great Auckland side of the 1980s. His career covers important episodes such as the 1985 South African tour controversy and the impending secret talks that was part of the organising the "rebel" tour of the Cavaliers to South Africa in 1986, which Kirwan declined to take part which enabled him to be part of the "Baby Blacks" that defeated a powerful and infinitely more experienced French and the Alan Jones coached Wallabies that shocked the All Blacks by winning the Bledisloe Cup in New Zealand. Goes into the successful 1987 World Cup campaign, the Alex Wylie era and sheds some light on the debacle of the 1991 World Cup and the uneasy relationship between Wylie and Hart. He details his experience playing rugby in Italy, being "synonymous with money". Also discusses his anxiety attacks and pressures of being an All Black in the chapter aptly named Black Dog.

\section{T10}

Thomas, Paul. Straight from the Hart. Auckland: Hodder Moa Beckett, 1993.

Biography of former Auckland and All Blacks coach John Hart. Harts man-management- based coaching philosophy set new standards in provincial rugby performances. Auckland under his tutelage became the dominant force in New Zealand winning the Ranfurly Shield and National Provincial Championships. Hart became All Black co-coach with Brian Lochore and Alex Wylie for the first World Cup in 1987 which New Zealand won. Hart was controversially overlooked for the sole All Black coach position in favour of Canterbury's Wylie. They were re-united again for the 1991 World Cup, which had disastrous consequences for both men and New Zealand rugby.

T11

Thomas, Paul. Change of Hart. Auckland: Hodder Moa Beckett, 1997.

Continuing biography of the coaching career of Auckland and All Black coach John Hart. In 1993 , John Hart and Paul Thomas released Straight from the Hart (T10). Change of Hart continues where that book left off, and describes the political intrigue and machinations which surrounded the choice of All 
Black coach in 1994 and 1995, explaining how Hart almost became a player in World Rugby Corporation's (WRC) attempted takeover of the game, and giving a first hand account of the transition to professionalism. Paul Thomas goes inside the Hart revolution to tell how John Hart took the All Blacks to a higher standard. Hart set about creating a world class management team to guide the All Blacks, how Hart and his fellow selectors strove to restore consistency and stability to the selection process, and how the 1996 South African campaign was planned in minute detail.

Each test match is examined in depth, providing revealing insights into selection, tactical and refereeing issues and analysing the All Blacks' opponents and the key personalities. John Hart assesses the current state of New Zealand rugby, looks ahead to the tour of the United Kingdom and the 1999 World Cup, and reviews the issues facing the game as it enters the 21 st century.

\section{T12}

Thomas, Paul. A Whole New Ball Game : Confronting the Myths and Realities of New Zealand Rugby. Auckland: Hodder Moa Beckett, 2003.

Thomas examines rugby from the playground to the boardroom to answer the charge that the sport is facing a crisis. Despite the evidence that New Zealand rugby has managed the transition to professionalism reasonably well there is a perception that the game has lost its way and is in serious decline at the grassroots. Thomas finds the game transformed often for the better but faces serious challenges to its traditional place in world rugby. He looks into issues such as the browning of New Zealand rugby and white flight. He compares contemporary rugby of the late 1990 s and early 21 st century to that of the 1950 s and 1960s. He analyses the effect of talk back on public expectation of the All Blacks. Thomas looks back at the history of the All Blacks and highlights that even in the past New Zealand teams would go through difficult patches. He takes a wider look at the charge that society is to blame for the decline of rugby and describes the new environment that comes with professionalism and how that potentially changes the perspective of the professional players. From the professional era comes other peripheral factors that have to be taken into account such as player burn out. The corporate environment, academy system, marketing and professional administrators that are accused of not being "real rugby people" and grass roots rugby are other issues investigated. 
Thompson, Richard. "The Effects of Protest: Half Time." Landfall 23, no. 91 (1969): p 293-98.

Thompson argues that there is substantially less support for protest in 1969 than there was in 1959 because it was the exclusion of Maori rugby players that moved the bulk of people to protest. The government's failure to require the NZRFU to order its international activities so as to be compatible with national race policy reflects deep sympathy in the government ranks for white dominance in southern Africa.

Many of younger Maori do not share their elders view on the issue. The rationalisation of the supporters of continued sporting relationship with South Africa is that the tour will benefit the Africans themselves. The NZRFU uses the same tactics it used in 1960, that is, refuse to discuss the race restrictions in the tour. This was an effective short term tactic but in the long run leaves the rugby union open to criticism.

Thompson reported that in 1959 there were few apologists for apartheid but in 1969 there are a number of New Zealanders who are willing to give apartheid a recommendation. New Zealand's future racial harmony is not so assured that this development can be viewed without concern.

\section{T14}

Thompson, Richard. "Raising the Colour Bar in Sport." New Zealand Monthly Review 10, no. 109 (1970): p13-14.

Some of the most courageous of the early opponents of apartheid felt at first that sport was not sufficiently important to merit serious attention, however there is now a growing awareness that the colour bar must go from sport. South Africa is under threat of being excluded from international competition if it continues apartheid. Some South African sports bodies such as the Athletics and amateur cycling seek to include non whites, however their significance remains to be seen. One thing is clear: nothing has moved white South Africans to show some concern for the plight of non-white sportsmen as has the possibility that they too will share something of the same isolation. International tours bring substantial financial returns. In New Zealand the exclusion of non white South African players is of little concern. Some New Zealanders argument for Maoris to be included is because they are "superior" to South African blacks and coloureds. If the 1958-60 controversy had to argue the rights of Maoris, this present controversy must argue the humanity and rights of non white South Africans.

The NZRFU is powerful but also vunerable. It relies a lot on allies such as church, school, government and commerce and these allies can be embarrassed for only so long. It needs the goodwill of the public. No sport has so vigorously supported South Africa's right to operate a colour bar as has rugby. The South African argument that non whites hardly play the game is also shown to be a fallacy. 


\section{T15}

Thompson, Richard. "No Politics in Sport!" New Zealand Monthly Review 12, no. 129 (1971-72): p 14-15.

With Christchurch winning the right to host the 1974 Commonwealth games there appears to be a threat from the desire to have the 1973 Springbok tour of New Zealand. The African nations have threatened to boycott the games. The pro-tour faction's excuse of "no-one has any jurisdiction over national sports bodies, government or Commonwealth Games body" is shown to be a falsehood. The conservative Citizens Association stands to profit from ridding Christchurch of financial liability, to strike a blow for the 1973 Springbok tour and to embarrass the Labour city council for losing the games. It is no use for the Prime Minister to say that the Government does not interfere with sport as both the Government and Opposition parties are deeply involved in the Christchurch dispute.

\section{T16}

Thompson, Richard. "Commonwealth Gamesmanship \& the Tour." New Zealand Monthly Review 13, no. 138 (1972): p 6.

Article looks at the threats from the African Nations to boycott the 1974 Christchurch Commonwealth Games while the desire to have both Commonwealth games and a Springbok tour come unstuck. The New Zealand Prime Minister's efforts to secure a Springbok team selected on merit without discrimination falls down when South African Minister of Sport and Recreation reaffirmed that the Springbok team represented whites only.

T17

Thompson, Richard. "Mr. Marshall on Race and Sport." New Zealand Monthly Review 12, no. 132 (1972): p 8-10.

Thompson deconstructs the Prime Minister's speech which argues that not only can New Zealand have the 1973 South African tour but also have it for the highest moral reasons. He highlights the clash of interests between the Commonwealth Games and the Springbok tour. Thompson illustrates the lack of frankness when it came to explaining the veiled threat from African nations to New Zealand. Prime Minister Marshall and Scott appear to be unduly worried about a black boycott of the Commonwealth Games. 
Thompson, Richard. "The Rugby Union States Its Case." New Zealand Monthly Review 13, no. 134 (1972): p 7-9.

Chairman of the NZRFU Jack Sullivan gives the most comprehensive defence of the Rugby Union's continued sporting association with South Africa. Thompson gives it careful examination and negates some of the statements. Points of contention and debate were: The tour is on the IRB list of tours and the NZRFU declined the invitation to tour South Africa in 1967 because the invitation breached the "fundamental right" to select their representative teams from among their own players. The NZRFU did not negotiate tours with any Government or political organisation, it dealt only with governing bodies of Rugby Football. The Games organising Committee believed it had the support of Rugby people throughout New Zealander and the only purpose of meeting protest leaders would be to learn their point of view and they did not believe it could be seriously suggested in view of the length and extensive publicity given to their many statements that they are not fully aware of their views. The Rugby Union was convinced that the substantial majority of New Zealand citizens were in favour of maintaining sporting contacts with South Africa and that sporting links between countries, irrespective of political or other opinions, are probably more important now than they have ever been.

\section{T19}

Thompson, Richard. "Wheels within Wheels." New Zealand Monthly Review 13, no. 142 (1973): p 13.

Article looks at Labour Prime Minister Norman Kirk's letter to the Rugby Union outlining the Government's reasons for objecting to the proposed 1973 Springbok tour. The obscurantism of the NZRFU and National Party proved a "continual source of provocation and major factor in the potential disorder". They seem unable to look past the need to protect the Springbok team to the broader question of the significance and the implications of the tour for the welfare of the country as a whole. Scott, the Chairman of the Commonwealth Games Organising Committee provided a letter to the then Prime Minister John Marshall which acknowledged the Springbok tour as a threat, however Marshall was reluctant to release the report. Thompson believes the Labour Government right to try and persuade the NZRFU to withdraw its invitation. There are occasions when the national interest demands that Governments should interfere in the affairs of sports bodies. 
T20

Thompson, Richard. "Rugby, Apartheid and the Commonwealth Games." New Zealand International Review 9, no. 1 (1984): p 16-19.

Discusses the dilemma posed by the Gleneagles Agreement for New Zealand's sportsmen. Code of conduct drawn up by the Commonwealth would spell out the requirements of the Gleneagles Agreement and give the Commonwealth Games Federation the right to suspend a country from the Games if there was a gross breach of the Agreement. At first New Zealand Lance Cross, president of the New Zealand 
with the Arabs and Chinese relations. The country's image is tarnished abroad. The Government's efforts to counter criticism led Mr Talboys to reaffirm the government's opposition to apartheid, and would continue contributions to United Nations Trust Funds for Southern Africa. There appears degree of ambivalence in the government's pursuit of better relations with Africa.

T22

Tuitupou, Essendon. " The acquisition of human capital in various currencies: the dual career dynamics of professional rugby " University of Auckland, 1997.

The transition in the sport of rugby union from an amateur status to professionalism has resulted in a significant expansion of professional sports industry. It has also resulted in an important expansion of professional sports career options. The thesis examines the career impacts of rugby professionalism by looking at its influence on players' perceptions, expectations and experiences. Several career development issues are analysed across various levels, from secondary school players through retired All Blacks, with particular emphasis placed on the idea of 'sacrifice versus benefit'.

The study provides evidence that there exists among players at various levels: unrealistic expectations of playing professional rugby; a short to medium term career focus and concern regarding recent developments.

The thesis concludes that career development beyond professional rugby requires both the individual and the respective unions to adopt a pro-active approach to player education and vocational training.

\section{T23}

Turner, Brian. Meads. Auckland: Hodder Moa Beckett, 2002.

A biography of the former New Zealand and King Country lock Colin Meads gives his impressions of how rugby has evolved since his playing days in the amateur era to the age of professionalism. He recounts the 1986 Cavaliers tour and his tenure as Manager of the All Blacks. Other episodes of his career are playing against hard man Keith Murdoch. Meads talks of the aspects of violence that characterised his era and how it compares today. 
Verdon, Paul. Hartbreak Years: Celebrity Books, 2000.

Takes a critical look at the man management style and behind the scenes politics of John Hart and attempts to blame the debacle of the 1999 World Cup and the poor results of the All Blacks at his feet. Professionalism in the New Zealand game is also explored and Verdon offers his opinion how New Zealand can return to its former glory, starting with the appointment of Wayne Smith. Verdon infers that Hart did not pick on form and had not prepared the team sufficiently as he had been out of top coaching for too long and believes Smith has a better understanding of the game and will not stoop to playing mind games with the players.

V2

Verdon, Paul. "Heat of Moment Unearths 'No-Brainers'." The National Business Review 2003, no. 31 January (2003): 20.

Verdon looks back at the Cavaliers' situation, partially brought on by the shamateurism of the day. Of all sports, rugby, controlled by the Victorian and Edwardian corinthian ethics of the International Rugby Board, was one of the last to bow to professionalism. The rebel Cavaliers in 1986 were one of the first teams to grab the commercial opportunity in the game. Former All Black coach Fred Allen admits he turned down big money to coach the Cavaliers.

V3

Veysey, Alex. Colin Meads All Black. Auckland, Collins, 1974.

Biography of All Black locking great Colin Meads. Meads gives frank opinions about the men he has played with, and against plus the referees, the coaches and the press.

The colours he wore were to be honoured by his total effort, whether they were the colours of his club Waiete, his province King Country, or his country, New Zealand. To that end he prepared himself thoroughly. When the day's work on his hill-country farm was done, he took himself off into the dusk, rain or fine, to run so that he might be able to give everything to his club, his province or his country.

Farming described as his other passion, family roots deep into the land. "I'm No Angel" looks into the early brushes Meads had with the rugby authorities. 
It was one of his greatest fears after being sent from the field at Murrayfield that this catastrophic experience would bedevil for the rest of life, would shroud from the recognition of those who followed the simple fact that he was an All Black. He said "I do not want to be remembered as Colin Meads, the man who was sent off in the test at Murrayfield, I want to be remembered as Colin Meads, the man who was an All Black. Just that."

Upon reflection the attitude of rugby at that time, 1956 was something which made it more than a game. There might now be uncomfortable reflections on the New Zealand attitude of that time. The chapter "Rough and Tumble" illuminates the attitude to aggression and violence on the field, much attributed to 'Tiny' Hill who Meads describes as "...a player who hurt you when he brushed against you. But he was not a dirty player. He was one of the greatest rakers of them all, but I never knew him to kick a man." New Zealand rugby has, through the years, been sorted out as the prime example of over vigorous play. There had been occasions when even its most patriotic observers have shivered at the cold ferocity with which New Zealand forwards have sought dominance. Yet ferocity of purpose is one thing and blatant assault another. Meads describes the gamesmanship amongst the opposing players. While Meads does not espouse any rugby philosophy which condones premeditated violence, he has been the central figure in several incidents which have roused international emotions.

V4

Veysey, Alex. Fergie. Christchurch: Whitcoulls Publishers, 1976.

Biography of Fergie McCormick, popular Canterbury icon, hard man and fullback known for his abrasiveness and courage. He gives us his reflections on alcohol and its consequences in "Novice Lion hunter". He describes his battle to get the fullback position in the face of strong competition and his loyalty to his club. McCormick gives his perspective of the 1966 Lions manager Des O'Brien and captain of the day Jimmy Telfer delivering a scathing attack castigating New Zealand for deliberate illegalities and dangerous play indulged by the provinces after their violent match with Canterbury. McCormick explains his own attitude to touring South Africa and describes the violent incidents with himself and Sid Nomis and the fallout involving New Zealand rugby writer Terry McLean that upset McCormick. The infamous 1971 Canterbury-Lions match renowned for its violence is covered in "Farewell, silver fern". 
V5

Veysey, Alex. Ebony and Ivory: The Stu Wilson, Bernie Fraser Story. Auckland: Moa, 1984.

Story of Stuart Wilson and Bernie Fraser, Wellington and All Black wingers during the late 1970s and early 1980s. Veysey examines the 1981 Springbok tour and how the public debate affected the two players and their families and explores the temptation to join David Lord's professional rugby in 1983 and give an insight into what the players actually think about getting paid to play. In "What mortal sin" Wilson takes a critical look at rugby administrators including the IRB at their conservative attitude towards player allowances and royalties from books. Also includes a chapter that gives the wives perspective of the rugby community and their views on contact with apartheid South Africa.

V6

Veysey, Alex, Gary Caffell \& Ron Palenski. Lochore: An Authorised Biography. Auckland: Hodder Moa Beckett, 1996.

The biography of former All Black captain, number 8 and coach Brian Lochore from his early life on the farm to becoming an All Black, through to his coaching career. Lochore provides justification for continuing a relationship with South Africa, viewing it as better to work from within to break down apartheid than from without in the chapter "On the road again". He continues that theme in "A time of disruption" with his meeting anti-apartheid activist Sam Ramsamy and recounts his experience dealing with the cancellation of the 1985 tour to South Africa of which he would have been coach. The rebel Cavaliers tour and the "baby blacks" is examined in "baby sitter". The plunge into professionalism after the 1995 World Cup is discussed in "A game in crisis" where Lochore looks behind the scenes at the NZRFU reaction to the WRC attempt to poach players to their professional circus.

V7

Vincent, G. T. (Geoffrey Thomas). ""Practical Imperialism": The Anglo-Welsh Rugby Tour of New Zealand, 1908." University of Canterbury, 1996.

A thesis submitted in partial fulfilment of the requirements for the degree of Masters of Arts in History in the university of Canterbury. Vincent takes the 1908 Anglo-Welsh tour and puts it in the context of an Imperial touring network that was seen as an important means of preserving vitality and unity within the British Empire. While impressing upon the colonies British cultural values it also became an 
opportunity for the colony to develop their own national identity within the setting of Empire. The AngloWelsh tour was a response by the Rugby Football Union in England to the perceived threat of professionalism infiltrating the New Zealand game that would possibly result in a severing of the Imperial connection. However the home union had underestimated how different the game was in New Zealand from the strictly amateur code played in Britain. The New Zealand Rugby Union was divided on how to respond to the "Northern game" consequent upon the return of the "Pro-Blacks" from Britain. The means by which this problem would be resolved would decide the fate of New Zealand's link with the Imperial touring network which was also hinged to the success of the Anglo-Welsh tour which was a dismal failure. The disparity between the two rugby cultures led to friction throughout the tour over a variety of issues, not the least being rough or violent play. Ironically as a consequence of the failure by the Anglo-Welsh which had come to bind New Zealand ever closer to Empire, New Zealand rugby was in effect isolated from the Imperial touring network.

\section{V8}

Vincent, Geoffrey T \& Toby Harfield. "Repression and Reform : Responses within New Zealand Rugby to the Arrival of the 'Northern Game', 1907-8." New Zealand Journal of History 31, no. 2 (1997): 234-49.

The article examines the response of the amateur New Zealand Rugby Football Union (NZRFU) to the perceived threat of the professional 'Northern game' of the English Northern Union which became rugby league, in 1907 and 1908. Vincent focuses on the effects of the perceived threat on conflicts within the NZRFU.

W1

Wallace, Bruce. "The Backroom Boys of Rugby." New Zealand Listener 69, no. 1689 (20 March 1972): p 8-9.

Wallace talks to the seven Wellington based members of the executive committee which is at the core of Rugby's power structure. With the Rugby Union under attack for being out of step with followers over the status of rugby and others taking it to task for its attitude to South Africa, live television coverage and innate conservatism with real power held by a select inner circle Wallace provides an insight into those who hold the reigns of power. These include Jack Sullivan, Ernest Todd, Cecil Blazey, Maurice Ingpen, Jack Griffiths, Frank Kilby and Ivan Vodanovich. Wallace looks at their rugby pedigree and procures their thoughts on contact with South Africa. 
W2

Wallace, Bruce. "Friends of South African Rugby." New Zealand Listener 70, no. 1698 (1972): p 8-9.

Supporters of the 1973 Springbok tour claim majority opinion is on their side. The five leading organisations and their leaders are examined to discover just how wide their support is and who represents it.

W3

Watkins, Glenn G. "NZ Futures and Recreation : Rugby, Racing, Beer?" New Zealand Parks and Recreation 3, no. 1 (1988): 7-15.

Forcasts how population changes and the technology and information explosion will challenge the traditional sports like rugby. Economic factors and the Hillary Commission on Sport and Recreation are discussed.

\section{W4}

Whetton, Alan \& Gary Whetton with Paul Lewis. Brothers in Arms. Auckland: Moa, 1991.

Autobiography of Auckland and All Black forwards Allan and Gary Whetton, twins who played a leading part in the dominance of the All Blacks in the 1980s. Gives an insight into the politics of player power and the financial sacrifice players make while giving their opinion on the possibility of professionalism. In the chapter "A babe in arms" describes the drama and controversy of Gary making his debut against the Springboks in 1981."When the knives came out" examines the public pressure on the All Blacks when they start to lose.

W5

Wike, Rachel. "Brawl at Kids `Thugby' Blamed on the Parents." Truth, 22 May 1998, 5.

Parents have been blamed for channelling sideline violence onto the school "thugby" field by top rugby officials. Children are been pushed too far and inciting violence. 
W6

Williams, Daniel. "Islanders: Rugby's Biggest Winners." Time South Pacific, no. 45 (2001): p16.

Reports that decreasing numbers of white people play rugby in New Zealand and how more people are playing soccer. This helps explain the impact of parental concern on rugby numbers with Increase in the number of Maoris and Pacific Islander participants and the influence of an individualistic New Zealand society on sports.

\section{W7}

Wilson, Jeff with Ron Palenski. Seasons of Gold. Auckland: Hodder Moa Beckett, 2000.

The autobiography of Jeff Wilson, who became a double international when he represented New Zealand in both rugby and cricket before he turned 20 . He talks about the relationship between rugby and alcohol, and players involved in late night incidents. Wilson laments the impossibility of playing two top level sports due to the increased number of internationals in the last stages before rugby went professional. He passes his concerns about the lack of older experienced talent and the almost indecent haste for teenagers to be rushed into top rugby. The tour to Argentina in 1994 introduced him to the rough play of the Latin rugby players. He expresses exasperation at being reminded of the George Gregan tackle that denied him the match winning try against Australia in 1994. He asks what is in the New Zealand psyche that finds it so difficult to praise, yet so quick to condemn.

Wilson responds to the criticism that the All Blacks had been "corporatised" and had lost sight of the real values of the game and were more focused on making money and living the lavish lifestyle than on preparing for and playing the games. Wilson counters that assertion with pointing out that the advent for rugby players has also greatly increased the workload and criticises the New Zealand Union for signing up too many sponsors who want the All Blacks to front their campaigns as it becomes too time consuming and belittles the All Black brand. He focuses on his association with Nike and the consequent fracas with Mizuno. He details his relationship with the media and the influence of talkback radio. Wilson reflects on the 1995 World Cup and the end of year tour to Italy and France where French foul play features. Wilson devotes a chapter on the rugby war between the establishment game, represented by the New Zealand Rugby Football Union, and the World Rugby Corporation and his decision to sign with the NZRFU and profiles the beginnings of professionalism after more than a century of amateur rugby and the implications that followed. Embarking upon the winning tour of South Africa he reveals his attitude towards South Africans. He laments that that there has yet to be a satisfactory balance struck with the workload of professional players. 
"End of the dream" profiles the build up and playing of the 1999 World Cup, the disappointment of the semi final exit at the hands of France and the vitriolic public backlash against the All Blacks and in particular the coach John Hart revealing the ugly intolerant side to New Zealanders.

\section{W8}

Wright, Vernon. "The Politics of Sport." New Zealand Listener 85, no. 1935 (22 January 1977): 1012.

With the international reaction to the All Blacks tour of South Africa in 1976 that led to the boycott of the Montreal Olympics, and the impending threat to the Edmonton Games Wright looks at the evolving relationship between sport and politics in New Zealand and overseas and at the present position of the Muldoon government. The events indicate that New Zealand can no longer vacillate on the politics in sport issue. The article emphasises and illustrates the place of rugby in New Zealand and white South Africa culture. Rugby is seen as quasi-religion. Continued contact with South Africa seen as damaging to New Zealand's international reputation.

\section{W9}

Wright, Vernon. "Enemies in All Black Country." New Zealand Listener 86, no. 1963 (6 August 1977): p 19-24.

Wright follows the Lions, in particular Philip Orr and JJ Williams, and gives a perspective on New Zealand rugby, society and New Zealand's most cherished myths. Williams thinks New Zealanders don't appreciate individualism, but value forward play, hard play but without any flair. The players refer to hostility of crowds while Rugby is seen not so much as a religion but a political movement. Complaints from Lions that New Zealand take their rugby too seriously, from boorish supporters to aggressive style on the field.

\section{W10}

Wright, Vernon. "Pro Rugby: Whats the Name of the Game." New Zealand Listener 89, no. 2012 (22 July 1978): p 14-16.

With the forces of professionalism ready to storm the bastion of amateur rugby, Wright investigates the leaders of the movement including World Professional Rugby Football Ltd prepared to 
start later in the year. The pros and cons of professional rugby are discussed while a lack of media weapon and lack of viable sponsors are seen as a weakness for World Professional Rugby Football. NZRFU chairman Ces Blazey expresses his unhappiness with the arrangement. Former players express their hopes on the likelihood of professionalism as well as voicing dissatisfaction with the NZRFU. Wright discusses the image of amateur rugby, boozing and machismo. There is definite promotional potential for rugby but the NZRFU may yet see authority disappearing unless it changes some of the ground rules.

\section{W11}

Wright, Vernon. "Apartheid under Attack." New Zealand Listener 110, no. 2374 (1985): p 23-24.

Wright looks at the South African response to the cancellation and outlines the major factors threatening the stability of the apartheid regime.

\section{Z1}

Zavos, S. (1992). "Kea Kaha." Metro (127): 74-80. Zavos, Spiro. "Kea Kaha." Metro, no. 127 (1992): 74-80.

Zavos argues that rugby has been a civilising force in our race relations. He recalls his childhood as an outsider using sports as a pathway to respectability, recognition and self-knowledge. Sport should be colour blind as it focused on what a person does as opposed to what their background, culture or looks were. Rugby in New Zealand from the 1880s provided the paradigm for how New Zealand society should practise "politics of inclusion". Examples include the 1888 Natives tour, where Joe Warbrick, a Maori, was given leadership of the team. Aspects of Maori culture were readily assimilated into rugby lore such as the haka, where in other aspects of life in New Zealand, the haka was feared and loathed. Aspects of racist attitudes toward Maori by Pakeha are explored which makes the rugby more significant as a focal point of bringing Maori and Pakeha together. The concept of rugby and team, every man being equal is constant theme of rugby talk and behaviour. The world of rugby was the only area of life in New Zealand where Maori enjoyed positions of power. Zavos remains at odds with Jock Phillips' assertion that rugby prevented Maori from being assimilated into New Zealand life. A black mark on rugby was the relationship with apartheid South Africa. This rugby ethic of inclusion is now being applied to Pacific Islanders who now exert a major influence in New Zealand rugby. 


\section{Z2}

Zavos, Spiro. The Gold and the Black. St Leonards: Allen \& Unwin Pty Ltd, 1995.

Zavos illustrates the story of Australian and New Zealand rugby rivalry through the eyes of players, referees, officials, fans and other writers. He brings to life great matches of the past and reintroduces great players such as Dally Messenger, Billy Wallace, Cyril Towers, Colin Meads and Sean Fitzpatrick.

Notable incidents that are investigated are: Colin Meads maiming Ken Catchpole; the latent hostility in Australian Rugby to New Zealand, the Richard Loe "thuggery" and the resurgence of Australia as a rugby super power. 


\section{Index of Rugby Bibliography}

A

Academic institutions, G5

Academy of rugby, G5, R23, T12

Adidas, $\mathrm{H1}, \mathrm{H} 2$, M4, M26, R23

Administrators, see New Zealand Rugby Football Union administrators

Advertising, G9, K8

African nations, T15, T16, T17

Afrikaneer Nationalism, see also South Africa, M53

AGB McNair, A1

Aggression, C13, D8, J1, L2, V3

Alcohol, D6, G8, H18, L3, L6, L11, P9, Q7, R17, V4, W7, W10

Alcohol advisory Council, D6

All Blacks Club, H24

All Blacks management,

- $\quad$ criticism of, B5, H11, V1

All Golds, H9, S7

Allen, Fred, B5, F7, J13, K9, V2

Allen, Mark (Bull), H8

Amateurism, see also Professionalism, B12, B15, D2, E1, F3, G3, G9, G12, G20,

H1, H2, H10, K1, L3, P1, R23, R25, R26, T12

- approaching professional era, H12, H19, H23, H24, K8, L11,M5, M62, P3, P7, Q6, R3, S4, T6, T11, V6, W7, W10,

- $\quad$ preparation for, H12, H24, M44, M61, M62, P7, S6, T7, T11, V3, V4, V5, W4, W7

- $\quad$ virtues of, H18, J3, K1, K5, K8, L3, M5, M11, M31, M39, M44, M62, P3, Q6, R18, R23, T5, T7, T12, T23, V2, V8, W7

- Working party, T6

Anglo-Welsh tour 1908, V7

Anti-Australian sentiment, G22, Z2

Anti-tour movement (with South Africa), see also Protestors, C16, D1, D4, H25, 
K7, K11, L2, L7, M1, M9, M41, M44, M45, N3, Q6, R8, R14, R28,

R36, T4, T13, T14, V5

Apartheid, D1, G16, L2, M41, M47, M54, M56, T16, T20, W11

- $\quad$ NZ's attitude to, B2, K1, L7, M41, M45, N3, R14, R15, R16, R29, S5, T4, T13, T14, T20, T21, W1, W2, W8

- $\quad$ players attitude to, G3, H1, H18, H24, K7, K8, L3, R28, V5

Ashworth, John, H18, K8, M48, M52, Q7

Australia

- 1968, M39

- $1972, \mathrm{~K} 7$

- 1974, H16

- 1978, V5

- 1980, C2

- 1986, V6

Australia - New Zealand rivalry, P3, Z2

Australian Rugby Union (ARU), M20, Z2

B

Baby Blacks, T9, V6

Back play, R11

Bad behaviour, see also aggression and violence, H1, H12, H17, L3, M47, P3, Q2, R12, T7, W5, W7

Baker, Erin, $\mathrm{C} 16$

Ball, Murray, H2

Barbarians, H16

"Battle of Solway", M46

"Battle of the bridge", Q7

Batty, Grant, H16

Baxter, James, N8

Beaumont, Pat, G7

Becker, Jaap, K10, Q7

Belich, James, R13

"Big business", B7, E1

Bishop, Ken, S16 
Black Ferns, C12

Black consciousness, M45

Blackadder, Todd, G13

Blazey, Cez, G7, M60, R28, W1, W10

Blues, Auckland, J7

Boe, John, G21

Boston Report, K15

Boycotts, see also sanctions L7, M45, N3, N7, T4, T15, T16, T17, T18, W8

Brown, Bruce, B14

Brownlie, Cyril, M5, M30, M46, Q7, S5

Brownlie, Maurice, M54, P3

Bruce, Tony, G6

"Butchers" match, M46

C

CABTA (Citizen's All Black Tour Association), N4

Canterbury

- Fans, H12

- $\quad$ v Lions 1971, G11, M57, Q7, V4

CARE (Citizens Association for Racial Equality), N3, N4

Carozza, Paul, H24, J1, M57, O4

Catchpole, Ken, M37, Z2

Cavaliers, D4, F5, H2, H20, J11, J12, J13, K5, K8, M37, M62, O1, O2, O4, P1, Q7, R21, S4, T23, V2, V6, W4

- political opposition to, D4

Cavanagh, Vic (Senior), O3

Cavanagh, Vic (Junior), $\mathrm{O} 3$

Christchurch Boys High School, L8

Christs College, L8

Citizens Association, T15

Clamp, Mike, R26

Clarke, Don, D2, R27

Cleland, Sam, C16

Clifford, John, G7 
Club rugby, K8, K16, M35, R23, R27, R30, R31, R37, S5

\section{Coaching}

- $\quad$ abroad, H12, H23, S2

- coaches (of All Blacks),

- $\quad$ Allen, Fred, B5, F7, J13, K9, P3, V2

- Deans, Robbie, G18, M28

- Duncan, Jimmy, M54

- Duff, Bob, M43, T7

- Gleeson, Jack, H15, M48

- Hart, John, F5, G11, J6, K6, K17, L25, P3, P7, Q6, Q7, T9, T10, T11,

$$
\text { V1, W7 }
$$

- Hunter, Gordon, M34

- Lochore, Brian, K9, P3, V6

- Mains, Laurie, H23, H24, P3, R9

- Mitchell, John, G17, M28, R2

- $\quad$ Stewart, JJ, D8, M45

- Vodanovich, Ivan, G7, M42, W1

- Wylie, Alex, F5, G11, M37, P3, Q6, T7, T9

- coaches (other),

- Boe, John, G21

- Cavanagh, Vic (Senior), O3

- Cavanagh, Vic (Junior), O3

- Griffiths, Jack, W1

- Grinter, Chris, R13

- Henry, Graham, H12

- James, Carwyn, M42

- Jones, Alan, T9

- foreign coach, (potential for), G14

- $\quad$ criticism, G1, J10, M42, M43, M44, M58, T10, T11

\section{Collective employment contracts, M19}

Colonial New Zealand, C14, L7, R17

Commercialisation, B15, C6, D2, E1, G4, G6, G20, H1, H2, H10, H13, H24, K5, K17, L3, L4, L5, M47, M48, M63, P1, R22, S15, T8, T12, W10 
Commonwealth (British), B10

Commonwealth Games, N3, T15, T16, T17, T18, T19, T20, W8

Compensation, see player renumeration

Conway, Matt, C16

Cooke, Bert, M54

Cooper, Greg, H24

Corporatization, see New Zealand Rugby Union

Coughlan, Tony, B18

Craven, Danie, B9, O4

Cribb, Ron, M24

Cross, Lance, T20

Crowd behaviour, M47, M48, T7, W5, W9

Cullen, Christian, B19, M28

Cultural appropriation, M8

Cultural hegemony, E1, S14

\section{D}

Dalton, Andy, B5, H2, H10, K8, K9

Dawes, John, H15, M42, M43

De Glanville, Philip, H24, O4

Deaker, Murray, D6

Dean, Stan, M54

Deans, Bob, S5

Deans, Robbie, G18, M28

Desmarais, Fabrice, G6

Devlin, Martin, D5

Dick, Malcolm, K11

Discipline, M38, M39, M42, M45, P8, R18

Disparity of wealth, M2

Don, Ron, C3, G7, R29

Donald, Rod, $\mathrm{C} 16$

Douglas, Jamie, C16

Dowling, John, K15

Duncan, Jimmy, M54

Duff, Bob, M43, T7

Dutton, Roy, T20 
$\mathbf{E}$

Eagle, Mike, G15

Earl, Andy, G10, Q7

Economy, effect on, H11, W3

Egalatarianism, K1, M12, R37, Z1

Eichelbaum Report (2002), B6, E2, M22, S9

Eligibility, H7, M16

Elitism, L4

Ellison, Tom, M54, R18

England, see also Tour to Britain, Ireland and France

- $\quad 1905, \mathrm{P} 9$

- 1924, M30

- $1993, \mathrm{H} 24, \mathrm{O} 4$

- $\quad 1995$, B4, K17

- 1999, M3

$\mathbf{F}$

Fairplay, S15

Fans, L3, L4, M47, M61, M63, Q2

Farming, M61, V3

Fatiolofa, Peter, F1

Fieldings Old Boys, A3

FIRA (International Federation of Rugby Amateur), M56

Fisher, Rob, M20, M22

Fitzpatrick, Sean, D6, F3, H24, M63, O4, Z2

Food poisoning, Q6, Q7

Foreskin's Lament, C14, R7

forward play, B1, M5, M43, M44, M47, M48, R11, R12, S5, T7, T8, V3, W9

Fox, Grant, F5

France, see also Tour to Britain, Ireland and France, G18, P3

- 1961, M5

- 1968, M5, M39

- 1977, V5

- 1979, V5

- 1981, V5 
- 1986, V6

- 1990, G11

Franchises, M29

Fraser, Bernie, M52, O2, V5

Freeman, Bill, G7

Freyberg Cup, S5

Funding, K12, R31, S6

G

Gallagher, John, B15

Gallaher, Dave, M54

Gambling, R18, R23

Gaming laws, R31

Geldenhuys, Burger, H2, K8

Gender

- images of, A2

- identity, H25

Gilbert, Mike, Q7

Gill, Pat, G7

Gleeson, Jack, H15, M48

Gleneagles, M48, T20

Global season, M36

Globalisation, G6, H14

Going, Sid, H17, M43, M44, T7

Golden oldies, G8

“Grass roots" see also club rugby, H22, J8, K15, M10, M11, M35, R23, R27, T12,

$\mathrm{T} 23$

Greed (of administrators), B7, L18, R23, W7

Greed (of players), J5, L15, L20, R9, R23, T1, T22, T23,

Greeson, Tim, J8

Griffiths, Jack, W1

Grinter, Chris, R13 


\section{H}

Haden, Andy, B5, H1, H2, H18, J12, O2, P1, R7

Haka, C1, Z1

Hard man, concept of, L11, M37, O4, S4, V3, V4

Harper, Ray, G7

HART, H4, K11, M9, N3, N4, R8, R14

Hart, John, F5, G11, J6, K6, K17, L25, P3, P7, Q6, Q7, T9, T10, T11, V1, W7

Henry, Graham, H12

Hewitt, Norm, C6, D6, L6, L11, P5

Hewson, Allan, G3, K11

Higginson, Graeme, Q7

High Court injuction (1985), C9, D4, H1

Hillary Commission of Sport and Recreation, W3

Hobbs, Jock, G15, H21, H24, K15, M27, S10

Hobbs, Marian, C16

Homoeroticism, S14

Homophobia, S15

Holyoake, Keith, T21

Hunter, Gordon, M34

Hunter, Jimmy, M54

Hurricanes, $\mathrm{H} 8$

I

Imperialism, B16, B17, P8, R17, R34, V7

Individualism, R6

Ingpen, Maurice, W1

injuries

- cost, G21

Innes, Craig, B18

International programme, K12, R32, R33

International Rugby Board (IRB), B7, G9, H10, J5, L3, L18, M5, M20, M56, P3, $\mathrm{R} 18, \mathrm{R} 24$ $\mathrm{S} 8, \mathrm{~S} 12, \mathrm{~T} 2, \mathrm{~T} 6, \mathrm{~V} 5$

International Rugby Hall of Fame, B9 
Intimidation, mental and physical, $\mathrm{O} 4$

Invincibles, B1, M12, M30, N8, P3

Ireland, see also Tour to Britain, Ireland and France, M43, M44, P3

J

Jackson, Steven, D6, G6

James, Carwyn, M42

Jansen, Eben, M37

Jersey, P2

John, Barry, M42

Johnson, Tom, G7

Jones, Alan, T9

Jones, Ian, K13, M25, Q1

Jones, Michael, L25, M33

Jones, Stephen, B5

Joseph, Jamie, H24

Judicial panel, B11

K

Keene, Howard, C16

Kelleher, Byron, M14

Kilby, Frank, W1

Kings Cup, M30

Kirk, David, J11, K5, K6, K9, O4, R21

Kirk, Norman, N3, T19

Kirkpatrick, Ian, H16, K7, K9

Kirwan, John, H10, T9

"kiwiness" see also National Identity, C2

Kiwis, S5

Kronfeld, Josh, H23, K17 
$\mathbf{L}$

Laidlaw, Chris, K11, L3

Laws of Rugby, K8

Le Roux, Johan, F3, H24, Q7

League, see Rugby League

Leslie, Andy, R6

Leslie, John, H23, K9

Lind, Clive, $\mathrm{C} 16$

Linesmen, B11

Lions

- 1930, M12, P3

- $\quad \mathbf{1 9 5 0 , M}$ M, P3

- $\quad 1959, \mathrm{~L} 1, \mathrm{M} 5, \mathrm{P} 3$

- $\quad$ 1966, M5, V4, P3

- $\quad$ 1971, K7, M42, P3

- 1974 (to South Africa), M44

- $\quad$ 1977, H15, H16, M47, P3, Q2, T8, W9

- $\quad 1983, \mathrm{M} 52, \mathrm{P} 3$

Littlejohn, Dick, K14

Loan system, L21

Lochore, Brian, K9, P3, V6

Loe, Richard, H24, J1, M57, O4, Q7, Z2

Lomu, Jonah, G4, R23

Lord, David, G3, K8, M58, P1, T2, V5

Loskop Dam, G16

Lowe, Graham, B12

Luyt, Louis, J11, Q7

M

McCaw, Murray, M20

McCormick, Fergie, H18, M37, M41, V4

McGee, Greg, R7

McGruther, Dick, M13

McLean, Terry, H17, K1, R14, V4 
MacEwan, Ian, D6

"Mafia", H16, H17, Q6

Mains, Laurie, H23, H24, R9

Manawatu v Lions 1983, M58

Maori culture, J2

Maori Advisory Board, S5

Maori rugby, B13, B19, L5, L9, M5, M6, M8, M42, M49, M50, M51, N8, Q6, R34, $\mathrm{S} 5, \mathrm{Z} 1$

- $\quad$ allowed in South Africa, G16, H17, M41, N8, Q7, T14

- $\quad$ attitudes to, M5, M50, S5, T3

- $\operatorname{good}$ will tours, B13, L16

- $\quad$ test status, L16, M5

Marketing of rugby, G12, H2, K8, K15, M2, R30, S15, S16, T12, W7

Marshall, John, T17, T19, T21

Masculinity, A2, C14, E1, G17, H25, K1, L8, L10, L11, M7, M8, M34, M37, N1,

N3, N5, N6, N7, O3, P1, P3, P5, P6, P8, P9, R17, R18, S13, S14, S15,

W10

- exclusion of, A2

Mateship, P9

Mather, Bob, $\mathrm{C} 16$

Meads, Colin, L1, L3, M37, M38, M41, O1, P3, Q6, R11, T23, V3, Z2

- being sent off, F7, M38, P3, S5, T23, V3

Media, C2, C8, L4

- $\quad$ antagonism, C2, D6, G11, G16, H16, H24, K1, K7, K17, L3, M17, M42, M43, M44, M45, M48, O4, P1, P3, R12, T7, T23, V3

- $\quad$ criticism, H1, H2, H24, J1, K7, L3, L18, L19, M48, M61, R8

- marketing, G12, K8, R30, S14, W10

- obligations, C8, P1

Messenger, Dally, Z2

Mexted, Murray, M62, O2 
Mill, Jimmy, N8

Minto, John, H12, R8

Missionaries of Empire, B16, P3

Mitchell, Neville 'Brushy', M54

Mitchell, John, G17, M28, R2

Mitchell, Paul, G7

Mitchinson, Frank, M54

Mizuno, W7

Moascar Cup, S5

Moffet, David, D6, K15, Q1

Mohi, Hinewehi, J2

Mourie, Graham, K9, M48, M65, Q7

Muldoon, Sir Robert, B10, H15, T21

Munro, CJ, S5

Munster, M28

Murdoch, Keith, C6, D6, G11, H1, H2, H16, H17, H18, K7, M43, P3, Q6, Q7, R12, T23

Murdoch, Rupert, B12, H24, J3, K3, M13

\section{$\mathbf{N}$}

Nathan, Waka, G7

National cult of rugby, $\mathrm{C} 14$

National Party of New Zealand, N3, T19, T21

National identity, B16, E1, G6, G17, H25, L5, L19, L22, M7, M8, N1, N3, N5, N6, P2, P8, P9, R13, R17, R18, R37, T7, T12

National Provincial Championship (NPC), G13, H12, K13, L21, T10

Nationalism, B16, C14, H25, M48, M53, N1, N6, P1, R7, R19, S14

Natives 1888-89, M8, M49, R18, R34, R35, Z1

Neo- fascist representations, $\mathrm{S} 14$

Nepia, George, D2, N8, P3

New image rugby, S14

New South Wales 1992, O4

New Zealand Broadcast Corporation (NZBC), C8

New Zealand Institute of International Affairs, B14

New Zealand Rugby 
- "browning of", B15, R23

- culture, H22, R23, R37

- dropout, N6

- $\quad$ image of, C4, D8, R23, W10

- origin of, C15, D2, M29, P1, P3, R18

- $\quad$ problems with, C4, D8, H11, M42, R23, S7, T5, W6

- $\quad$ social importance, E1, P1,P3, R30

\section{New Zealand Rugby Football Union (NZRFU)}

- academy, G5

- administration reform, S6

- administrators, B18, D2, L11, M60, T12, W1

- antagonism, D2, H2, H12, M50, V3

- corporatisation of, $\mathrm{H} 22, \mathrm{~K} 15, \mathrm{P} 7, \mathrm{R} 23, \mathrm{~T} 11, \mathrm{~T} 12, \mathrm{~W} 7$

- councilors, C9, G7

- criticism of, A1, B6, C4, D6, E2, G15, H1, H2, H12, H18, H22, J8, K14, L3, L18, M5, M20, M21, M22, M32, M42, M57, N3, N8, P1, P4, R22, R23, R28, S8, S9, T5, T12, T13, T14, T19, T20, V1, W1

- current operations, B7

- disciplinary process, $\mathrm{C} 5$,

- legal wrangles, M24

- managerial model, S6

- $\quad$ philosophy, D3, R24, T20

- $\quad$ politics, G11, H24, L3, M6, M42, V8

- professionalisation of, H13, J3, M31, P7, R23, R25, S2

- progressive corporates, G12

- reaction to player/coach drain, $\mathrm{H} 12, \mathrm{~S} 2, \mathrm{~V} 6, \mathrm{~V} 8$

- responsibility to players, D6

- revenue, $\mathrm{D} 3, \mathrm{H} 2, \mathrm{R} 33$

- $\quad$ strategic review, R30, R32

New Zealand society (general), C1, C13, D8, H20, K1, K6, K16, L1, L6, L7, M42, M48, M53, N1, P1, P6, R16, S14, T5, W8

- colonial, B16, D2, C15, L7, M8, M30, O3, P8, P9, R17 R34, V7, Z1

- conformity, L3, M2, R16, R17

- contemporary, C14, D2, J4, L1, L12, M48, M58, R13, R16, R27, S5, T12, W3, W6, W9

- economics, H11, M4 
- Great Depression, M12, N8

- homogenous, E1, H25, R16, R17, R19, T12, T13

- "kiwiness", $\mathrm{C} 2$

- morale, L22, M3

- nostalgia, N6, P2, R19

- patriarchal society, P8

- $\quad$ (effect of) protest, C16, R15

- $\quad$ racial traditions, $\mathrm{B} 17, \mathrm{R} 17$

- rural, M10, R27

- settler, see colonial

New Zealand - South Africa rivalry, B17, H6, K1, M2, M53, M55, N3, N6, N7, O4, P3, Q6, Q7, R15, R16, R19, R36, S5, T23

New Zealand - Wales rivalry, C2, K8, M40, M46, M48, P3, Q3, R17, S5, T7, T8

News Corp, see News Limited

News Limited, B12, F3, H24, M13

Nichol, Rob, M23

Nicholls, Mark, M54, S5

Nike, W7

Nomis, Sid, H18, M41, V4

Northampton, S4

Northern Rugby Football Union, S7

Norton, Tane, M27

O

O'Brien, Des, V4

Oliver, Frank, M37

Olympic games, N3, W8

O'Neil, Damian, B3

O'Neill, John, F2, L18, M20

Opinion polls, $\mathrm{C} 8$

Orr, Philip, W9

Otago, L26, O3 
$\mathbf{P}$

Pacific Island players, see Polynesian players

Pacific Islands, B8, H7, M16, S12

Packer, Kerry, B12, K3

Pakeha, B19, L9, P9, R10, R36, S11

Pan - African, D1

Paramore, Junior, Q1

Penalties, B11

Phillips, Jock, M8, Z1

Player, see also individual player names

- $\quad$ abroad, H1, H2, M62, R7, S4, T9

- $\quad$ agent, M24, R23

- association, L20, M23

- $\quad$ attitude, M17, M41, R9, T5, T12, T22

- $\quad$ development, K4, M29

- dissatisfaction, S7

- drain, H12, M17, M19, M25, M26, M28, Q7, S2

- education, T22

- exodus, L15

- $\quad$ experience, T22

- $\quad$ expectations, T22

- $\quad$ fatigue, J8, M23, R5, R32, T12

- motivations, L17, S1, S5, T12, T22

- movements, K13, M59

- occupation, R37

- $\quad$ philosophy, D8

- $\quad$ power, M48, O4, V1

- pressure, C6, H24, T22, W7

- relationship with fans, L4

- renumeration, D4, G3, G9, G12, H2, H10, H18, J4, J5, J11, J12, J13, K8, L4, M24, O2, Q5, R9, R18, T12, V2, V5

- retention, L18

- revolt, $\mathrm{J} 7$

- rights, D2, H2, M19

- transfer, M14 
Playing abroad, G13, H23, R23, T9

Polynesian players, B15, D7, F1, G21, H7, H18, H19, L5, L9, L18, L24, M2, M16, M18, M33, M41, R10, R13, R20, R23, S11, S12, T12, W6, Z1

Porta, Hugo, K8

Police, C16, Q1

Political

- relations with the international community, B14, G16, N3, N4, N7, R6, R7, T4, T13, T15, T18, T19, T20, T21, W2, W8

- usage of rugby, B16

Ponsonby RFU, F1

Popular culture, L10, S14

Porter, Cliff, M54

Prince of Wales Cup, S5

Pro-tour sentiment, C3, C16, G7, H1, H2, H25, K11, L7, M65, N3, R6, R29, T4, T13, T16, T18, V5, W1, W2

Professionalism, see also amateurism, B5, D3, G5, K4, L12, R13, S1, S3

- amateur players attitude to, B13, G3, G12, H1, H2, H10, H12, K7, K8, L3, M58, P1, R3, R7, W4

- beginnings of, B12, F3, J4, J5, K3, K17, M29, Q5, T2, T11, T23, V6, W7

- centralization, M59

- clash with amateur ideals, G20, H1, H2, H10, J4, L4, L11, M5, M14, M43, M48, O3, P1, Q6, R7, R18, R23, T12, T23, V1, V2, V7, W10

- criticisms of, B7, B8, G15, K12, K13, K16, L4, L13, L15, L21, M5, M13, M14, M63, P1, Q6, R23, R30, T1, T12, T22, V1, W7, W10

- $\quad$ earlier forms of, D4, H9, H23, O3, Q7, R18, V2, V7, V8

- effects on Polynesian community, M18, R10

- mental application, H12, L11, T12, T22

- preparation, H12, K17, L11, R23, T22, T23, V1

- $\quad$ strategic choice, F4, R25

- transition from amateurism, F4, G15, H8, H10, H12, H14, J4, K3, K6, K16, L11, P1, R23, $\mathrm{S} 1, \mathrm{~S} 2, \mathrm{~T} 11, \mathrm{~T} 12, \mathrm{~T} 22, \mathrm{~T} 23$

Promotion, S16

Propaganda, C3 
Protestors, A3

- $\quad$ history, C16, M2, M7, M9, N7

- reaction to, $\mathrm{A} 3, \mathrm{H} 1, \mathrm{H} 2, \mathrm{M} 9, \mathrm{M} 37, \mathrm{M} 41$

- violence towards, $\mathrm{C} 16$

Provinces, B8, L18

Pub culture, see also alcohol R17, V4

Public misbehaviour, B18

Public expectation, H25, K17, M61, T1, T12, V3, W4, W7

Public Opinion Survey, A1

Public reaction to rugby, D5, G22, H25, J2, L3, L11, M27, M37, O4, T7, T9, T12, T14, T18, W4, W7 - $\quad$ to defeat, B3, C7, G17, H14, J6, K17, L11, L22, M4, M48, M61, O4, R2, T1, T12, V3, W7

Pugh, Vernon, L18, M20, R4

\section{Q}

Quinn, Paul, B13

$\mathbf{R}$

Race divide, L18, M41

Race relations, B14, B17, D1, H25, M9, M41, N3, N4, N7, P1, P9, R16, R17, R23, R34, R36, T3, T12, T13, T16, T20,T21, W8, Z1

Racism, H19, H24, H25, J2, K5, L24, L25, M2, M8, M41, M64, N4, N7, N8, Q7, R14, R23, S13, Z1

Ramsamy, Sam, V6

Randell, Taine, J6

Ranfurly Shield, H17, L26, S5

Rangi, Ron, Q7

Reaction to defeat, see public reaction to defeat

Recordon, Philip, C10

Refereeing

- $\quad$ abuse, G2, M1, Q4

- $\quad$ criticism, G16, M39, M43, M44, M52, M58, Q7, T8

- interpretations, F7, M38

Reilly, John, C16

Renumeration, see player renumeration

Richards, Huw, S4 
Richards, Trevor, M9, M64, R14

Rituals, L26

Roberts, Kevin, M26

Rowlands, Jed, J7

Royalties, V5

Rucking, M58, O4, V3

Rugby League, B14, G12, H18, M37, Q7

- influence on Rugby Union, H24, P1

- Manley rugby league club, B12

- $\quad$ poaching rugby players, $\mathrm{H} 19, \mathrm{~N} 8, \mathrm{P} 1, \mathrm{~S} 7, \mathrm{~V} 8$

- relationship with Rugby Union, G20, H9, M5, M15, S7

Rural, see also Grass roots, L10, R37

Rutherford, David, M35

S

Salary cap, K13

Samoa, F1, G10, M33, R24

Sanctions (against South Africa), T4

SANZAR, M6, M13, M36

Saunders, Chris, D7

Saxton, Charlie, M54

Schools

- decline, C11, R30

- $\quad$ effect of professionalism, R1, R13, R23, T22

- establishment, R18, S5

- $\quad$ ethics, D7, L8, W5

- injuries, $\mathrm{C} 11$

- $\quad$ poaching, D7, R23

- skills, J10

- $\quad$ social status, J3, L8, P8, R23, R27, R30

Scotland, see also Tour to Britain, Ireland and France, P3

- $\quad 1967$, F7, L3, R11

- 1993, H24, O4 
Scrum

- 2-3-2, B1, M30, N2, N8

- evolution of, B1

Seddon, Richard, P8, R17

Services rugby, M29, S5

Sevens, G22

Sexuality, H25

Shamateurism, M62, R23

Sharp, Stuart, G7

Shaw, Mark, M37

Shelford, Wayne (Buck), F5, G11, H10, K9, M37, Q6, S4

Skinner, Kevin, A2, H20, K10, Q6, S5

Smith, Doug, G11, M42

Social conditions, B17, H25, N2, N5, N6, N7, P6, P8

Social rugby, G8

Socio-economic, K16

Socio-historical, C15, L25, M2, M12, N1, R34

Socio-psychology, C14,

South Africa, B2, B14, B17, H6, P3

- $\quad$ 1921, B1, B17, H6, M12, M46, M50

- $1928, \mathrm{~B} 1, \mathrm{~N} 8$

- $\quad \mathbf{1 9 3 7 , B} 1, \mathrm{~B} 17, \mathrm{H} 6, \mathrm{M} 12, \mathrm{R} 36$

- $\quad 1949, \mathrm{~B} 1, \mathrm{~B} 17, \mathrm{H} 6$

- $\quad$ 1956, A2, B1, H6, K10, L2, M5, M46, M50, M57, P3, R19

- $1960, \mathrm{~V} 3$

- $1965, \mathrm{~V} 3, \mathrm{~V} 4$

- $\quad$ 1970, D1, H6, H17, H18, K7, L3, M41, O5, R14, V3, V4, V6

- 1973 (proposed), K7, L2, M41, T15, T16, T19, W2

- $\quad$ 1976, G16, H6, H16, H17, H18, H24, K7, M45, W8

- $\quad$ 1981, C3, C15, C16, G3, H1, H2, H6, K8, K11, M7, M62, N4, N6, R15, R28, S14, T3, T20, V5, W4

- 1985 (proposed), A1, C8, C9, C10, C15, D4, H2, H6, H25, K8, M62, R26, S4, T9, T20, V6, W11

- legal battles, D4 
- media view of, G16

- South African response to cancellation, W11

- $\quad 1992, \mathrm{H} 6$

- $1994, \mathrm{H} 6$

- $\quad 1996, \mathrm{~T} 11, \mathrm{P} 3$

- solution to touring, $\mathrm{H} 1$

- sporting contacts with, B10, G7, H4, H15, L2, L7, M2, M9, M44, M48, M55, M56, M64, M65, N3, O1, O5, P1, R6, R8, R28, R29, S5, T4, T13, T14, T18, T20, T21, W1, Z1

South Pacific Championship, B15

Spin doctors, $\mathrm{R} 23$

Sponsorship, D6, G12, H24, K17, L4, M6, M26, R23, R31, T8, W7, W10

Sportsmanship, M12

Springboks, see South Africa

Stanley, Noel, G7

Stanley, Joe, G10, Q7

Stead, Billy, M54

Steinlager, H24

Steinmetz, Paul, M14

Stewart, JJ, D8, M45

Stoicism, L10

Stuart, Bob, G7, K9

Style, B1, C2, F7, G16, H24, L2, L3, L9, M5, M30, M37, M38, M39, M41, M42,

M43, M44, M45, M48, M51, M53, M58, N2, P1, P3,P7, R9, R11, R12,

R18, R20, R23, S5, S6, T5, T7, T8, T11, V3, W9

Sub-host debacle, see World Cup Sub-host debacle

Sullivan, Jack, M50, T18, W1

Super 10, H12, K17

Super 12, F3, F4, G13, H8, H12, J7, K13, K17, M15, M25, M29

- $\quad$ expansion, $\mathrm{K} 2$, M36

- merchandising, M63

$\mathbf{T}$

Talboys, Brian, T21

Talent identification, R13, R23 
Talkback, D5, M17, W7

Television

- advertising, E1

- commercialization, H13, J4

- coverage, B11, E1, H1, H13, H20, M42, S3, S14

- $\quad$ effect on culture, H14

Television New Zealand (TVNZ), S13

Telfer, Jim, V4

Tew, Steve, M20, M22

Thomas, Russell, G7, M48

Thompson, GWF, C3

Thorne, Graham, $\mathrm{H} 2$

Timaru Boys High School, L8

Todd, Ernie, H18, T7, W1

Tour to Britain, Ireland and France

- $\quad$ 1905, B1, B16, N2, N5, P3, P8, P9, R11,

- $\quad$ British response to, N2, N5, P9, R17

- economic impact, N2

- 1924, B1, P3, R11,

- $1935, \mathrm{~B} 1, \mathrm{P} 3$

- 1963-64, R11, P3

- $\quad 1967, F 6, M 38, R 11, P 3$

- $1972-73, \mathrm{H} 1, \mathrm{H} 2, \mathrm{H} 16, \mathrm{H} 17, \mathrm{M} 43, \mathrm{M} 44, \mathrm{M} 46, \mathrm{P} 3, \mathrm{Q} 6, \mathrm{~T} 7, \mathrm{R} 12$,

- $\quad$ 1978, H18, M48, P3

Towers, Cyril, Z2

Trans-tasman relations, F2, G22, M42

Tri-nations, B5, F3, K17, L17, M15, V1

Tuigamala, Vaaiga, H19, L24, S12

$\mathbf{U}$

Ubogu, Victor, H24

United Nations, B2

University rugby, S5

Urbanisation, L10, P9 
Van Heerden, Moaner, M45

Verry, George, K15

Verwoerd, Hendrik, G16

Violence, (general examples of) see also aggression, B1, C13, G11, J1, K1, K6,

L3, L11, M5, M34, M37, M38, M44, M57, P2, P3, P5, P9, S5, T23, V3, $\mathrm{V} 4$,

- (with) Australia, H24, M39, Z2

- (with) Britain, F7, G10, H24, K7, M5, M38, M43, M48, M52, M58, Q2, S4, T8, V7, W9

- (with) club rugby, H16, G21

- (with) colonial New Zealand, C14, P9, V7

- $\quad$ crowd, G22, M1, M47

- domestic, B3, J1

- (with) France, G18, M39, V3, W7

- legal response, F6, H3, L23, Q1, Q4

- media treatment of, $\mathrm{J} 1, \mathrm{~S} 15$

- (with) New Zealand provincial rugby, H12, M46, Q4

- penalties, recommended, B11

- rationalization of, $\mathrm{A} 2, \mathrm{H} 5, \mathrm{H} 20, \mathrm{~L} 11, \mathrm{M} 12, \mathrm{M} 38, \mathrm{O} 4, \mathrm{~S} 4, \mathrm{~V} 3, \mathrm{~V} 4$

- (with) South Africa, D4, F3, G16, H2, H24, K8, K10, M41, M45, O4, Q6

Vodanovich, Ivan, G7, M42, P3, W1

\section{W}

Wales see also Tour to Britain, Ireland and France,

- 1969, M40

- 1972-73, K7

- 1974, M44

- 1978, M48

- $1980, \mathrm{C} 2, \mathrm{Q} 3$

Wales - New Zealand rivalry, see New Zealand - Wales rivalry

Wallace, Billy, M54, Z2

War, R18

Warbrick, Joe, Z1

"Welshness", C2

Western Samoa, see Samoa 
Whetton, Allan, W4

Whetton, Gary, K11, S4, W4

Whineray, Wilson, $\mathrm{K} 9$

White flight, L12, L21, M18, R10, R23, S11, T12, W6

White, "Tiny", K9, Q7

Whiting, Peter, M45

Wigan, H19

Wild, Peter, G7

Williams, Bryan, H18, M41

Williams, JJ, W9

Williams, JPR, H18, K8, M48

Wilson, Jeff, M34, W7

Williams, Ray, T7

Williams, Steve, M37

Wilson, Stu, K11, V5

Wing forward, R17

Women, A2

Women's rugby, C12, R23,

World Cup, B7, P1, Q6, R33

- $\quad$ 1987, B14, F5, O4, S13, S14, S15, T9, T10

- $\quad$ 1991, F5, O4, R3, T9, T10

- $1995, \mathrm{~B} 4, \mathrm{H} 24, \mathrm{~K} 17, \mathrm{~T} 2, \mathrm{~W} 7$

- $1999, \mathrm{C} 7, \mathrm{E} 1, \mathrm{G} 17, \mathrm{H} 10, \mathrm{H} 14, \mathrm{~J} 6, \mathrm{~T} 1, \mathrm{~W} 9$

- 2003, B6, L14, R2

- losing the sub hosting rights see World Cup sub host debacle

- why it will fail, L14

- $\quad$ devaluing tests, G19

- players' attitude to, K8

- Sub-host debacle, B6, E2, F2, H21, H22, J8, K12, K14, L14, L18, M20, M21, M35, P3, P4, R4, R22, R23, S8, S9, S10

World Rugby Corporation (WRC), B12, F3, H21, H24, J11, K3, K17, T11, V3, V6,

W7

Wylie, Alex, F5, G11, M37, Q6, T7, T9 
X

Y

Young, Jeff, M40

Z 